\author{
SANDIA REPORT \\ SAND2006-3869 \\ Unlimited Release \\ Printed July 2006
}

\title{
Yucca Mountain Project Getter Program Results (Year 1): \\ I-129 and Other Anions of Concern
}

James L. Krumhansl, Jason D. Pless, J. Benjamin Chwirka, Kathleen C. Holt

Prepared by

Sandia National Laboratories

Albuquerque, New Mexico 87185 and Livermore, California 94550

Sandia is a multiprogram laboratory operated by Sandia Corporation,

a Lockheed Martin Company, for the United States Department of Energy's

National Nuclear Security Administration under Contract DE-AC04-94AL85000.

Approved for public release; further dissemination unlimited. 
Issued by Sandia National Laboratories, operated for the United States Department of Energy by Sandia Corporation.

NOTICE: This report was prepared as an account of work sponsored by an agency of the United States Government. Neither the United States Government, nor any agency thereof, nor any of their employees, nor any of their contractors, subcontractors, or their employees, make any warranty, express or implied, or assume any legal liability or responsibility for the accuracy, completeness, or usefulness of any information, apparatus, product, or process disclosed, or represent that its use would not infringe privately owned rights. Reference herein to any specific commercial product, process, or service by trade name, trademark, manufacturer, or otherwise, does not necessarily constitute or imply its endorsement, recommendation, or favoring by the United States Government, any agency thereof, or any of their contractors or subcontractors. The views and opinions expressed herein do not necessarily state or reflect those of the United States Government, any agency thereof, or any of their contractors.

Printed in the United States of America. This report has been reproduced directly from the best available copy.

Available to DOE and DOE contractors from

U.S. Department of Energy

Office of Scientific and Technical Information

P.O. Box 62

Oak Ridge, TN 37831

Telephone: $\quad$ (865) 576-8401

Facsimile: $\quad$ (865) 576-5728

E-Mail: $\quad$ reports@adonis.osti.gov

Online ordering: http://www.osti.gov/bridge

Available to the public from

U.S. Department of Commerce

National Technical Information Service

5285 Port Royal Rd.

Springfield, VA 22161

Telephone: $\quad$ (800) 553-6847

Facsimile: (703) 605-6900

E-Mail: $\quad$ orders@ntis.fedworld.gov

Online order: $\quad$ http://www.ntis.gov/help/ordermethods.asp?loc=7-4-0\#online

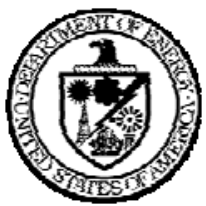




\title{
Yucca Mountain Project Getter Program Results (Year 1): I-129 and Other Anions of Concern
}

\author{
James L. Krumhansl* \\ *Geochemistry Department, 6118 \\ Jason D. Pless \\ CI Modeling \& Simulation II Department, 6222 \\ J. Benjamin Chwirka \\ Geochemistry Department, 6118 \\ Sandia National Laboratories \\ P.O. Box 5800 \\ Albuquerque, NM 87185-0754 \\ Phone: (505) 844-9093 \\ Fax: (505) 844-7354 \\ Email: jlkrumh@sandia.gov
}

\begin{abstract}
Although high level nuclear wastes (HLW) contain a daunting array of radioisotopes, only a restricted number are long-lived enough to be problematic, and of these many are either effectively insoluble or are likely to be scavenged from solution by minerals indigenous to all aquifers. Those few constituents likely to travel significant distances through aquifers either form colloids (and travel as particulates) or anions - which are not sorbed onto the predominantly negatively charged mineral surfaces. Iodine $\left({ }^{129} \mathrm{I}\right)$ is one such constituent and may travel as either iodide $\left(\mathrm{I}^{-}\right)$or iodate $\left(\mathrm{IO}_{3}{ }^{-}\right)$depending on whether conditions are mildly reducing or oxidizing. Conventionally, ${ }^{99} \mathrm{Tc}$ (traveling as $\mathrm{TcO}_{4}{ }^{-}$) is regarded as being of greater concern since it is both more abundant and has a shorter half life (e.g., has a higher specific activity). However, it is unclear whether $\mathrm{TcO}_{4}{ }^{-}$will ever actually form in the mildly reducing environments thought likely within degrading HLW canisters. Instead, technetium may remain reduced as highly insoluble $\mathrm{Tc}(\mathrm{IV})$, in which case ${ }^{129}$ I might become a significant risk driver in performance assessment (PA) calculations.

In the 2004-2005 time frame the US Department of Energy (DOE) - Office of Civilian Radioactive Waste Management (OCRUM), Office of Science and Technology International (S\&T) funded a program to identify "getters" for possible placement in the invert beneath HLW packages in the repository being planned by the Yucca Mountain Project (YMP). This document reports on progress made during the first (and only) year
\end{abstract}


of this activity. The problem is not a new one and the project did not proceed in a complete vacuum of information. Potential leads came from past studies directed at developing anion getters for a near surface low-level waste facility at Hanford, which suggested that both copper-containing compounds and hydrotalcite-group minerals might be promising. Later work relating to closing HLW tanks (Hanford and Savannah River) added layered bismuth hydroxides to the list of candidates.

In fact, even in the first year the project had considerable success in meeting its objectives (Krumhansl, et al., 2005). "Batch Kd" testing was used to screen a wide variety of materials from the above-mentioned groups. Some materials tested were, in fact, archived samples from prior studies but a significant amount of effort was also put into synthesizing new - and novel - phases. A useful rule of thumb in judging getter performance is that the "Kd", should exceed a value of roughly 1000 before it's placement can materially decrease the potential dose at a hypothetical (distant) point of compliance (MacNeil, et al., 1999). Materials from each of the groups met these criteria for both iodide and iodate (though, of course, the actual chemistry operating in "batch Kd" runs is unknown, which casts a rather long shadow over the meaning of such comparisons). Additionally, as a sideline, a few materials were also tested for $\mathrm{TcO}_{4}{ }^{-}$ and occasionally $\mathrm{Kd}$ values in excess of $10^{3}$ were also found for this constituent.

It is to be stressed that the "batch Kd" test was used as a convenient screening tool but in most cases nothing is known about the chemical processes responsible for removing iodine from the test solutions. It follows that the real meaning of such tests is just as a relative measure of iodine scavenging ability, and they may say nothing about sorption processes (in which case evaluating a Kd is irrelevant). Numerous questions also remain regarding the longevity and functionality of materials in the diverse environments in, and around, the proposed YMP repository. Thus, although we had a highly successful first year, we are still far from being able to either qualify any material for placement in the repository, or quantify a getter's performance for use in PA assessments. 


\section{ACKNOWLEDGMENTS}

Sandia is a multiprogram laboratory operated by Sandia Corporation, a Lockheed Martin Company, for the United States Department of Energy's National Nuclear Security Administration under contract DE-AC04-94AL85000.

This report was prepared by Sandia National Laboratories pursuant to a contract funded by the United States Department of Energy (DOE), Office of Civilian Radioactive Waste Management (OCRWM), Office of Science and Technology and International (OST\&I), and neither Sandia National Laboratories nor any of its contractors or subcontractors nor the DOE/OCRWM/OST\&I, nor any person acting on behalf of either:

Makes any warranty or representation, express or implied, with respect to the accuracy, completeness, or usefulness of the information contained in this report, or that the use of any information, apparatus, method, or process disclosed in this report may not infringe privatelyowned rights; or

Assumes any liabilities with respect to the use of, or for damages resulting from the use of, any information, apparatus, method, or process disclosed in this report. Reference herein to any specific commercial product, process, or service by trade name, trademark, manufacturer, or otherwise, does not necessarily constitute or imply its endorsement, recommendation, or favoring by DOE/OCRWM/OST\&l.

The views and opinions of authors expressed herein do not necessarily state or reflect those of the DOE/OCRWM/OST\&I. 


\section{CONTENTS}

$\begin{array}{ll}\text { Abstract } & 3\end{array}$

I. Introduction 9

II. Background 11

III. Batch Test Evaluation Process 13

$\begin{array}{ll}\text { IV. Results } & 14\end{array}$

a. Copper Delafossites and Spinels $\quad 14$

b. Hydrotalcites 15

$\begin{array}{ll}\text { c. Layered Bismuth Hydroxides } & 17\end{array}$

d. Miscellaneous Materials 29

V. Summary and Conclusions 31

$\begin{array}{ll}\text { VI. References } & 33\end{array}$

Appendix A: Selected supplementary data for this study 35

Appendix B: Results from earlier TFA-sponsored getter studies $\quad 40$

External Distribution $\quad 51$

Internal Distribution $\quad 54$

\section{FIGURES}

Fig. 1 Cinnabar (red) collected from a surface outcrop in north-central Nevada (Humboldt County). The orange staining results from the acidic iron-containing fluids formed as the iron pyrite $\left(\mathrm{FeS}_{2}\right)$ deposited along with the cinnabar was oxidized. Although the rock is, in general, highly weathered the cinnabar has remained untouched by the process.

Fig. 2 Comparative behavior before and after grinding iodide, perrhenate and arsenate. 
Fig. 3 lodide Log Kd vs pH behavior for two mixed-metal layered double hydroxides synthesized early in the program.

Fig. $4 \quad$ lodide Kd values determined with the post-grinding ratio of solid 27 to liquid; $0.05 \mathrm{~g}$ solid to $50 \mathrm{ml}$ of fluid. (from 4-26-05 pH adjustments)

Fig. 5 lodate $\mathrm{Kd}$ values determined with the post-grinding ratio of solid to liquid; $0.05 \mathrm{~g}$ solid to $50 \mathrm{ml}$ of fluid. (from 4-26-05 pH adjustments)

Fig. 6 SEM photographs showing different textures of Bi-based getters 29

$\begin{array}{lll}\text { Fig. A-1 Typical "Type I" diffraction patterns } & 37\end{array}$

Fig. A-2 Typical "Type II" diffraction pattern (p5-C). Marginally better for 37 $\mathrm{ClO}_{4}{ }^{-}, \mathrm{I}^{-}$and $\mathrm{ReO}_{4}{ }^{-}$

Fig. A-3 "Type III" diffraction patterns p85-m and p85- $\delta$, with a poorly expressed "Type II" pattern, p85-v below for comparison.

Fig. A-4 Additional Bi getter diffraction patterns.

\section{TABLES}

Table 1 Physical Properties and Sorption Coefficients of the Delafossites and Spinel Compounds

Table 2 Physical Properties and Sorption Coefficients of the Hydrotalcites

Table 3 Physical Properties and Sorption Coefficients of the Calcined Hydrotalcites

Table $4 \quad$ Batch "Kd's" for previously synthesized materials in a J-13 simulant (NT = not tested)

Table 5 Synthesis details and Kd results for various Round 1 - Bi-based 20 getters

Table 6 Sorption Coefficients of Bismuth Compounds

Table $7 \quad$ Kd values before and after grinding

Table 8 Summary of $\mathrm{pH}$ dependent $\mathrm{Kd}\left(\mathrm{I}^{-}, \mathrm{IO}_{3}{ }^{-}, \mathrm{ReO}_{4}{ }^{-}\right.$and $\left.\mathrm{AsO}_{4}{ }^{-3}\right)$ 
Table $9 \quad K d$ values for select Round 1 materials grouped by X-ray diffraction type.

Table 10 Sorption Coefficients of Miscellaneous Compounds

Table A-1 Comparison of recipe for "J-13 surrogate" with literature "J-13" composition

Table A-2 Supplemental $\mathrm{TcO}_{4}{ }^{-} \mathrm{Kd}$ information

Table A-3 X-ray diffraction characteristics of early-synthesized materials

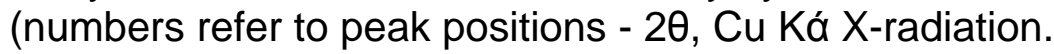

Table A-4 Synthesis notes and supplemental $\mathrm{Kd}$ values for materials synthesized in the first round of testing for this project.

Table B-1 Formulation for DSSF-7 $\left(7 \mathrm{M} \mathrm{Na}^{+}\right)$Hanford Tank Simulant

Table B-2 Summary of mixed metal hydroxides synthesized for this study

Table B-3 X-Ray diffraction characteristics of materials synthesized

Table B-4 Log Kds for $\mathrm{I}^{-}, \mathrm{SeO}_{4}{ }^{2}, \mathrm{ReO}_{4}{ }^{-}$, and $\mathrm{AsO}_{4}{ }^{-3}$ : $1 \%$ DSSF-7 fluid matrix and 1-day contact times.

Table B-5 Comparison of Log Kd values for 1-day and 26-day contact times.

Table B-6 Effect of ordinary Portland cement on iodine and selenium sorption

Table B-7 Effect of ordinary Portland cement ("OPC") on perrhenate sorption

Table B-8 Pertechnetate sorption test results.

Table B-9 $\mathrm{TcO}_{4}-\mathrm{Kd}$ values (not Log $\mathrm{Kd}$ ) for selected $\mathrm{HT}$ samples 


\section{INTRODUCTION}

A key element in fielding a high level nuclear waste repository at Yucca Mountain, Nevada is to demonstrate through the use of performance assessment (PA) models that dose rates at some distant point of compliance will not exceed regulatory limits. Implicit in this approach is the fact that the most mobile radionuclides present in natural groundwaters are likely to play a large role in determining the eventual suitability of the proposed facility. Although radioactive wastes have large radioisotope inventories, considerations of relative abundance, half life, solubility, and aqueous chemistry dictate that the chief elements of concern are technetium, neptunium, and iodine. Long-lived isotopes of selenium and cesium may also play a role in such assessments. However, they will not be of primary importance unless they are concentrated into some peculiar waste form prior to placement in a repository.

The current generation of PA models generally assigns higher priorities to technetium and neptunium than to iodine. However, such models universally overlook important chemical processes that may take place within waste packages as they deteriorate (Brady, et al., 2005). In particular, the waste canisters will contain vast amounts of metallic iron (along with $\mathrm{Ni}$ and $\mathrm{Cr}$ ), and the waste itself contains significant amounts of uranium dioxide; all of which are potential reducing agents. Although the conditions in the proposed repository are postulated to be oxidizing, there is every reason to believe that at least mildly reducing conditions will persist within, and around, waste packages for long after the first breach occurs (and leaching of the more soluble constituents is initiated). There is a substantial body of evidence suggesting that in such a setting both the Tc and Np will reduce to the tetravalent form and that these constituents (unlike $\mathrm{TcO}_{4}{ }^{-}$and $\mathrm{NpO}_{2}{ }^{+}$) will sorb strongly onto the rust formed as the waste packages degrade. Further, additional iron liberated by later corrosion will cover the sorbed constituents, effectively precluding the release of these constituents. If this scenario is verified, performance of the repository may depend largely on the behavior of more mobile, though less radioactive, ${ }^{129}$ I.

The objective of this document is to report on early success in developing materials that scavenge ${ }^{129}$ I. The rationale behind developing such scavengers ("getters") is that such materials could be placed beneath the waste with the crushed rock liner on the proposed repository floor (e.g., the "invert"). Here, they would then immobilize or delay the radioiodine before it could leave the repository facility (Jow et al., 2005). Although PA model development is an ongoing activity, some preliminary results (MacNeil et al., 1999) suggest that a rough metric for a "successful" getter (e.g., one that could impact the dose at the point of compliance) is that it will have an adsorption coefficient " $K_{d}$ " greater than $10^{3}$.

A getter's performance generally depends on the environment within the repository. This issue is discussed separately in some detail (Krumhansl, et al., 2006) but the main features of the environment are summarized below. The mountain "breathes" (e.g., changes in air pressure are noted within the mountain in response to outside changes in atmospheric pressure), so the YMP program position is that the repository will be as oxidizing as the earth's surface. It is also presumed that the $\mathrm{UO}_{2}$ fuel and metallic waste packages (or portions thereof) will be present in the repository for many thousands of years. This is relevant because iodine can travel in 
groundwaters as iodide $\left(\mathrm{I}^{-}\right)$, elemental iodine $\left(\mathrm{I}_{2}(\mathrm{aq})\right)$, and iodate $\left(\mathrm{IO}_{3}{ }^{-}\right)$. Iodate is the stable form in surface groundwaters. However, with all the metal and fuel presumed to be present (and its potential for locally producing reducing environments), a pragmatic choice is to focus on initially developing getters that effectively sequester $\mathrm{I}^{-}$.

Any successful getter must survive the thermal cycle of the repository and withstand several decades of dehydration. It is expected that the temperatures will peak at $120-160{ }^{\circ} \mathrm{C}$ and persist for several decades before slowly cooling below the boiling point of water. After that the temperature continues to fall slowly to about $50{ }^{\circ} \mathrm{C}$ after 10,000 years. During this period the getter probably will have to withstand prolonged "stewing” in mildly oxidizing or reducing aqueous fluids.

The fluids in contact with the getter are another important variable in determining getter performance. A survey of YMP literature defines three general classes of fluids:

(1) Indigenous groundwaters. All have low ionic strengths, are mildly basic and contain only the normal constituents of drinking water;

(2) Derivatives of normal groundwaters arrived at by evaporation. Depending on initial compositions, fluids may develop that contain high concentrations of alkali halide or nitrate with some carbonate and sulfate, or that are rich in alkaline earth metals with appreciable sodium, chloride and nitrate, but minimal sulfate and carbonate;

(3) Fluids whose chemistries are dominated by constituents derived from waste package corrosion processes. If interactions with the rust particle surfaces are not considered these fluids will be mildly to strongly acidic with appreciable nickel and chromate concentrations. Including the surface chemistry of the rust particles in the model, however, suggests that much less aggressive fluids will be formed. In fact, fluids will not differ greatly from the indigenous groundwaters except for having slightly elevated chromate concentrations. The chromate, of course, will only form if fully oxidizing conditions persist on the corroding metal surface. If oxygen is not freely available insoluble trivalent chromium compounds will form that are analogous to iron corrosion products.

The second type of fluids will have mostly left the repository before much of the radionuclide inventory could be leached out of the waste. Consequently, the greatest immediate concern for getter performance (and the only topic addressed in this report) is how potential getters perform in (more or less) normal YMP repository groundwaters. Parenthetically, had the study had continued for an additional two years (as initially anticipated) we would have also explored: (1) whether the early-formed waters might pre-load the getters with constituents that would later interfere a getter's ability to scavenge iodine and, (2) whether the early waters might react with a getter to make completely new phases - possibly leading to a complete loss of iodine-scavenging ability.

Our primary objective initially was to identify the most promising candidates from a rather extensive list of possibilities gleaned from past experience and from the literature. To simplify this process we employed a "batch Kd" technique and our test matrix was limited to assessing getter performance in a single fluid, “J-13 surrogate” (Appendix A, Table A-1 and Krumhansl, et 
al., 2006, in press) that resembles dilute groundwaters found near the YMP repository site. Further, the experiments usually had a short duration (days to weeks of contact time), and no attempt was made to thermally treat materials beyond what was inherent in their various synthetic procedures.

\section{BACKGROUND}

Sequestration of ${ }^{129} \mathrm{I}$ is not, at least formally, a very difficult problem and we had many leads going into the project (see the topic review by Mattigod et al., 2003). It has been known for some years that metal sulfides, and the mineral cinnabar (HgS) in particular, have a strong affinity for iodine (Ikeda et al., 1994; Balsley et al., 1996). Further, cinnabar is clearly stable for geological periods of time in mildly acidic and oxidizing surface groundwaters indigenous to central Nevada (Fig. 1). However, the inclusion of large amounts of a powdered mercurycontaining material in a working repository is probably not economically feasible, nor environmentally tractable.

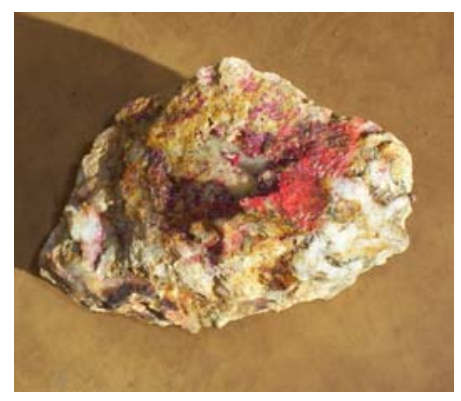

Fig. 1 Cinnabar (red) collected from a surface outcrop in north-central Nevada (Humboldt County). The orange staining results from the acidic iron-containing fluids formed as the iron pyrite $\left(\mathrm{FeS}_{2}\right)$ deposited along with the cinnabar was oxidized. Although the rock is, in general, highly weathered the cinnabar has remained untouched by the process.

Although using cinnabar to sequester iodine fails the "giggle test", the chemistry implicit in its behavior suggests a list of other potential iodide getters. Other metals, such as $\mathrm{Pb}, \mathrm{Ag}$, and $\mathrm{Cu}$ also form both essentially insoluble sulfides and sparingly soluble iodide salts. However there are draw-backs for lead and silver compounds. Placing lead compounds in the repository would raise many of the same environmental issues associated with mercury ( though, parenthetically, central Nevada is dotted with natural ore deposits which expose considerable amounts of $\mathrm{Pb}$ and $\mathrm{Hg}$ ( along with $\mathrm{Cu}$ and $\mathrm{Ag}$ ) on the surface so any conceivable activity at Yucca Mountain could only be a trivial perturbation on what nature has already created). For silver, there are obvious cost considerations (particularly given the 2006 silver market!). Further, AgI is unstable with regard to photo-dissociation, which places any AgI - related scavenging mechanisms at a clear disadvantage in a high radiation environment. Copper, on the other hand, is less environmentally problematic and less expensive. Reasoning along these lines motivated an earlier, partly successful, effort to develop copper-based iodine getters for use in a near-surface low level waste facility being contemplated at Hanford (Balsley et al., 1998). 
Part of the reason both iodine and technetium travel well in groundwater is that they form anions and, at normal groundwater $\mathrm{pH}$ values, the negatively charged mineral surfaces do not sorb anions. An alternate approach to finding iodine getters (also initially explored for potential Hanford applications, Balsley et al, 1998) was to survey the geologic literature for exceptional minerals with positive surface charges. In doing this, two classes of materials emerged: imogolite-type silicates and hydrotalcites (Fetter et al., 1997; Kang et al., 1999). Imogolite proved impractical because it was difficult to synthesize and the natural material (found as an impurity in some volcanic soils) had only a very limited capacity and specificity for iodide. Several hydrotalcite-group minerals, however, were found to have significant potential as iodide getters. The zinc-aluminum derivative is particularly easy to synthesize and therefore was used in most early studies. In the course of that work it was also found that the nature of the anions used to counterbalance the zinc and aluminum in the synthesis fluid affected the iodinescavenging ability of the getter.

Several years elapsed before the search for anion getters resumed; this time the motivation came from DOE-sponsored Tank Focus Area (TFA) efforts (in the 2001-2002 time frame) to place getters in decommissioned high level waste tanks. The primary focus of the research was to find sequestering agents for technetium (rather than iodine), but the materials advances, as well as scoping "sorption" studies made in the context of this investigation are noteworthy (Krumhansl, et al., 2002; selected TFA study results are also abstracted in Appendix B. Also see Harbour et al., 2004). Of help in guiding this study were several papers describing new "hydrotalcites" based on the use of heavier metals hydroxides (Velu et al., 1998,1999) and particularly the Sescavenging ability of a "hydrotalcites" fabricated from bismuth, in conjunction with zinc and magnesium (Tsuji et al., 2000).

The conventional hydrotalcite structure can be described as a layered metal hydroxide in which a portion of the octahedrally-coordinated divalent metal is replaced with a trivalent metal. The substitution imparts a net positive charge to the layer and creates a material capable of exchanging anions. In the mineral "hydrotalcite" $\left\{\right.$ formally: $\left.\mathrm{Mg}_{6} \mathrm{Al}_{2} \mathrm{CO}_{3}(\mathrm{OH})_{16} \cdot 4 \mathrm{H}_{2} \mathrm{O}\right\}$ layers are composed of magnesium hydroxide with aluminum substitutions to impart a net positive layer charge. The carbonate resides in the interlayer position to balance the positive charges on the hydroxide layers. This basic structural template also characterizes the other members of the hydrotalcite mineral group, in which almost all the various combinations of the first row transition metals with dominant +2 and +3 valences are observed. One unusual derivative of the conventional hydrotalcite structure involves exposing layered $\mathrm{Al}(\mathrm{OH})_{3}$ to concentrated $\mathrm{Li}^{+}$containing solutions. Some lithium ions diffuse into vacant octahedral sites and impart a net positive charge to the layer (Devyatkina et al., 1983; Lei et al., 2000).

A large ion such as $\mathrm{Bi}^{+3}$ (1.03 $\AA$ ) cannot, obviously, be accommodated on the octahedral site of a conventional hydrotalcite lattice. Although, the unusual bismuth "hydrotalcite" compounds posses structural similarities to the hydrotalcites, the materials described by Tsuji et al. (2000) cannot actually be members of the hydrotalcite mineral family. Thus, in addition to hydrotalcites, there are other apparently layered hydroxides that may provide additional avenues for developing iodide (and technetium) getters. Tests done in 2002 confirmed the basic 
radionuclide-scavenging ability of such Bi-materials (Appendix B). Later work has shown that several different layered pure Bi-hydroxide structures can be synthesized (Bontchev et al., 2005). Thus, in the two-metal mixtures it is not even certain that the second metal in the mix actually plays a role in the structure.

\section{BATCH TEST EVALUATION PROCESS}

The bulk of this report reviews the relative performances of the different classes of materials alluded to above. These comparisons are based on the results from what are commonly referred to as batch "sorption" tests - though mechanistic insights (sorption or not) are not actually implicit in data obtained in this manner. A brief description of the test process is given here, and a more detailed coverage of the underlying rationale can be found in a companion document (Krumhansl et al., 2006 - in press).

The batch sorption (or $\mathrm{K}_{\mathrm{d}}$ ) approach is particularly good at providing an efficient, cost-effective method for differentiating between poorly performing getters and those with some potential for iodide sequestration. The environment for the tests was chosen to superficially resemble what might be found in the YMP repository. Toward this end the test fluid contained reasonable concentrations of normal groundwater anions that might compete with iodide "sorption,". Experiments were also designed so that the iodine (and other contaminants of interest) would never be a major component in the dissolved load of the fluid. Thus, if something in a normal groundwater "interfered" with iodine sequestration then the empirical result obtained would show that this material had little potential as a getter (though any insight as to why the material had performed poorly would, of course, be unavailable). Finally, within the limits imposed by analytic sensitivities, the tests were conducted so that all the samples in a particular suite of experiments would be run at essentially the same solid to liquid ratios. The actual ratio, however, varied from suite to suite (typically 0.05 to 0.25 grams of solid in 25-60 ml of fluid), and changed as our understanding of getter performance advanced. Experience gained during the performance of these tests ultimately led to the protocols described in Krumhansl et al., 2006.

Analytical techniques vary depending on the constituent and analytic range desired. For iodide, the specific ion electrode was occasionally employed, but this was limited to a sensitivity of about $0.05 \mathrm{ppm}$. However, the specific ion electrode has the advantage of uniquely identifying the iodine species in solution since it is insensitive to both elemental iodine and iodate. Inductively coupled plasma - mass spectroscopy (ICP-MS) is more sensitive to iodine but suffers from two shortcomings. Unlike the specific electrode, ICP-MS is indifferent to aqueous speciation and so measures the total iodine content of the fluid being sampled. Also, in the case of iodide, the surface chemistry of the machine's internal plumbing is such that iodide is retained; resulting in serious memory effects (e.g. iodine is carried over from previous samples). This can be overcome by not acidifying the samples or standards, and using a rinse fluid consisting of one part (by volume) concentrated $\mathrm{NH}_{4} \mathrm{OH}$ in 19 parts de-ionized water and spiked with an AA standard to contain 5 to $10 \mathrm{ppm} \mathrm{Ag}^{+}$. Once the iodine analyses have been completed, the samples (and standards) can be acidified for the analysis of other elements that may also be of concern. Iodate is less strongly retained on the machine's internal surfaces than is iodide, and can generally be run without a special (basic) rinse. 


\section{RESULTS}

Several different classes of materials were identified at the onset of this study as potential iodide getters. In fact, there is some overlap because some of the criteria used in grouping materials are structural and some are compositional. The performance of the delafossites and their related compounds are discussed first. This is followed by a discussion of layered compounds: a) presumably, true multi-metal hydrotalcites and b) Bi-based getters. The last section reviews the performance of miscellaneous materials that don't fall into the other main categories. The main body of the text is largely in the form of tables and emphasizes the performance characteristics of the materials.

\section{a. Copper Delafossites and Spinels}

Delafossites have the general chemical formula $\mathrm{ABO}_{2}$ and can be described as alternating layers of edge-shared $\mathrm{BO}_{6}$ octahedra and two-coordinate noble metal A-site cations. This structure type can accommodate various monovalent $\mathrm{A}$-site cations $(\mathrm{Cu}, \mathrm{Pd}, \mathrm{Pt}$ and $\mathrm{Ag})$ and trivalent $\mathrm{B}$-site cations $\left(0.53<r\left(\right.\right.$ six coordinate $\left.\left.\mathrm{B}^{3+}\right)<1.09 \AA\right)$. The delafossite structure as an iodide scavenger is interesting because the copper is monovalent (thus resembling $\mathrm{Ag}^{+}$), and it is only 2coordinated (suggesting the potential for additional bonding - possibly with iodide). It was thought that $\mathrm{Cu}(\mathrm{I})$ might have an affinity to iodide that was similar to that of Ag, and form a similarly insoluble compound. Furthermore, the iodine might have relative access to the layered copper. After initial synthesis was completed select compositions were also oxidized because of the uncertainty of the environment inside the repository. The structure of the oxidized materials is spinel-like. The spinel structure can be described as layers of close-packed oxygen atoms with tetrahedral copper and octahedral tri-valent cations $\left(\mathrm{M}^{3+}\right)$.

Synthesis and Structural Characterization: Seven polycrystalline delafossites and three compositionally-related spinels were synthesized by solid state reaction (Table 1). Stoichiometric amounts of $\mathrm{Cu}_{2} \mathrm{O}$ (Alfa Aesar, 99.9\%), $\mathrm{CuO}$ (Alfa Aesar, 99.7\%), $\mathrm{Al}_{2} \mathrm{O}_{3}$ (Alfa Aesar, 99.9\%), $\mathrm{V}_{2} \mathrm{O}_{3}$ (Alfa Aesar 99.7\%), $\mathrm{Cr}_{2} \mathrm{O}_{3}$ (Alfa Aesar, 99\%), $\mathrm{Mn}_{2} \mathrm{O}_{3}$ (Alfa Aesar, 98\%), $\mathrm{Fe}_{2} \mathrm{O}_{3}$ (Alfa Aesar, 99.9\%), $\mathrm{Ga}_{2} \mathrm{O}_{3}$ (Alfa Aesar, 99.99\%), and $\mathrm{Y}_{2} \mathrm{O}_{3}$ (Alfa Aesar, 99.9\%) were ground with an agate mortar and pestle. The delafossites and spinels were calcined in flowing $\mathrm{N}_{2}$ and air, respectively, between $750-1100{ }^{\circ} \mathrm{C}$ for $24 \mathrm{~h}$. The materials were ground to a fine powder.

The samples' structures were identified using powder X-ray diffraction (XRD). The XRD patterns were recorded at room temperature on a Siemens Kristalloflex D 500 diffractometer $(\mathrm{Cu}$ $\mathrm{K} \alpha$ radiation, Kevex detector, $40 \mathrm{kV}, 30 \mathrm{~mA} ; 2 \theta) 5-60^{\circ}, 0.05^{\circ}$ step size and $3 \mathrm{~s}$ count time) and used for crystalline phase identification. The phases were identified by comparison with the data reported in the JCPDS (Joint Committee of Powder Diffraction Standards) database. 
Table 1. Physical Properties and Sorption Coefficients of the Delafossites and Spinel Compounds $^{\mathrm{a}}$

\begin{tabular}{|c|c|c|c|c|c|c|}
\hline Composition & $\begin{array}{l}\text { Structure } \\
\text { Type }\end{array}$ & $\begin{array}{l}\text { Calcination } \\
\text { Temp. }\left({ }^{\circ} \mathrm{C}\right)\end{array}$ & $\begin{array}{c}\log K_{d} \\
I^{-}\end{array}$ & $\begin{array}{c}\log K_{d} \\
\mathrm{IO}_{3}^{-} \\
\end{array}$ & $\begin{array}{c}\log \mathrm{K}_{\mathrm{d}} \\
\mathrm{ReO}_{4}^{-}\end{array}$ & $\begin{array}{c}\log K_{d} \\
\mathrm{TcO}_{4}{ }^{-}\end{array}$ \\
\hline $\mathrm{CuAlO}_{2}$ & Delafossite & 1090 & 1.5 & $<1.40$ & $<1$ & 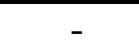 \\
\hline $\mathrm{CuCrO}_{2}$ & Delafossite & 1000 & 0.54 & 1.64 & 1.23 & - \\
\hline $\mathrm{CuMnO}_{2}$ & Delafossite & 960 & $<1$ & $<1.40$ & $<1$ & - \\
\hline $\begin{array}{c}\mathrm{CuMn}_{2} \mathrm{O}_{4}+ \\
\text { Impurity }\end{array}$ & Spinel & 750 & 0.94 & 0.00 & 0.00 & - \\
\hline $\mathrm{CuFeO}_{2}$ & Delafossite & 1050 & 1.5 & $<1.40$ & $<1$ & - \\
\hline $\mathrm{CuFe}_{2} \mathrm{O}_{4}$ & Spinel & 750 & 0.99 & 0.00 & 0.00 & - \\
\hline $\mathrm{CuGaO}_{2}$ & Delafossite & 1070 & 1.3 & $<1.40$ & $<1$ & - \\
\hline$\underset{\mathrm{Cu}_{2} \mathrm{O}}{\mathrm{CuO}_{2}}+$ & Delafossite & 1050 & 1.49 & 1.48 & 0.75 & - \\
\hline $\mathrm{CuY}_{2} \mathrm{O}_{5}$ & Spinel & 1050 & 1.04 & 0.27 & 0.00 & - \\
\hline $\mathrm{CuV}_{0.5} \mathrm{Fe}_{0.5} \mathrm{O}_{2}$ & Delafossite & 850 & - & $<1.40$ & $<1$ & - \\
\hline
\end{tabular}

a. Dash (-) indicates no test was performed.

Results and Discussions: The physical properties and sorption coefficients of the delafossites and spinels are summarized in Table 1 (Pless et al., 2006). The sorption capacities of the delafossites and spinels are relatively small. Most of the iodide $\log \left(K_{d}\right)$ values fall between 1 and 1.5. Interestingly, the iodate $\log \left(\mathrm{K}_{\mathrm{d}}\right)$ values of the delafossites is similar to the iodide $\log ($ $\mathrm{K}_{\mathrm{d}}$ ) values, but the iodate $\log \left(\mathrm{K}_{\mathrm{d}}\right)$ values of the spinel-like compounds become significantly smaller. The difference might be related to the local structure of the copper. The copper in delafossite is relatively open with only two bonds to oxygen, whereas the copper in the spinel is more surrounded with bonds to four oxygen atoms. So it is more difficult for the larger $\mathrm{IO}_{3}{ }^{-}$ anion to coordinate/bond to the copper. Finally, the $\mathrm{ReO}_{4}{ }^{-} \mathrm{Log}\left(\mathrm{K}_{\mathrm{d}}\right)$ values are unremarkable, falling between 1.25 and 0.75 for the delafossites and are 0 for the spinels. The difference again can be explained by the local environment of the copper atoms.

\section{b. Hydrotalcites}

As stated above, hydrotalcites (HTCs) are well known for their ion exchange abilities. A variety of hydrotalcites were synthesized by changing the divalent and trivalent cations in order to more fully study the sorption properties. In addition, it has been shown that the hydrotalcite structure collapses upon calcining due to anion and water loss. The collapsed material can be dispersed into an aqueous solution containing an ion and the HTC structure recrystallizes including the "new" ion. Select compositions were calcined because of the uncertainty of the environment inside the repository.

Synthesis and Structural Characterization: Nineteen polycrystalline hydrotalcites were synthesized by direct co-precipitation of the divalent and trivalent cations at room temperature. Stoichiometric amounts of $\mathrm{Mg}\left(\mathrm{NO}_{3}\right)_{2} \cdot 6 \mathrm{H}_{2} \mathrm{O}$ (Alfa Aesar, 98\%), $\mathrm{Co}\left(\mathrm{NO}_{3}\right)_{2} \cdot 6 \mathrm{H}_{2} \mathrm{O}$ (Aldrich, 98\%), $\mathrm{Ni}\left(\mathrm{NO}_{3}\right)_{2} \cdot 6 \mathrm{H}_{2} \mathrm{O}$ (Aldrich, 98.5\%), $\mathrm{Cu}\left(\mathrm{NO}_{3}\right)_{2} \cdot 2.5 \mathrm{H}_{2} \mathrm{O}$ (Aldrich, 98\%), $\mathrm{Zn}\left(\mathrm{NO}_{3}\right)_{2} \cdot 6$ $\mathrm{H}_{2} \mathrm{O}$ (Aldrich, $99 \%$ ), $\mathrm{Pd}\left(\mathrm{NO}_{3}\right)_{2}$ solution (Alfa Aesar, Pd $8.5 \% \mathrm{w} / \mathrm{w}$ ) or $\mathrm{Cd}\left(\mathrm{NO}_{3}\right)_{2} \cdot 4 \mathrm{H}_{2} \mathrm{O}$ (Alfa Aesar, 98\%) and $\mathrm{Al}\left(\mathrm{NO}_{3}\right)_{3} \cdot 9 \mathrm{H}_{2} \mathrm{O}$ (Alfa Aesar, 98\%), $\mathrm{Cr}\left(\mathrm{NO}_{3}\right)_{3} \cdot 9 \mathrm{H}_{2} \mathrm{O}$ (Aldrich, 99\%), 
Fe( $\left(\mathrm{NO}_{3}\right)_{3} \cdot 6 \mathrm{H}_{2} \mathrm{O}$ (Aldrich, 98\%), $\mathrm{Ga}\left(\mathrm{NO}_{3}\right)_{3} \cdot \mathrm{X} \mathrm{H}_{2} \mathrm{O}$ (Alfa Aesar, 99.9\%), or $\mathrm{La}\left(\mathrm{NO}_{3}\right)_{3} \cdot 6 \mathrm{H}_{2} \mathrm{O}$ (Alfa Aesar, 99\%) were dissolved in $400 \mathrm{~mL}$ of DI water. The $\mathrm{pH}$ of the solution was adjusted to $\sim 10$ with $\mathrm{NH}_{4} \mathrm{OH}$ (Fisher, Reagent), precipitating an HTC and turning the solution into a thick opaque suspension. This mixture was allowed to age for approximately 24 hours at room temperature. The product was filtered and washed until the conductivity of the filtrate was approximately 100 microsiemens. The product was dried overnight in air at $100{ }^{\circ} \mathrm{C}$. Select samples were calcined at $550^{\circ} \mathrm{C}$ between 1 and 24 hours. The materials were ground to a fine powder.

The samples' structures were identified using powder X-ray diffraction (XRD). The XRD patterns were recorded at room temperature on a Siemens Kristalloflex D 500 diffractometer ( $\mathrm{Cu}$ Ka radiation, Kevex detector, $40 \mathrm{kV}, 30 \mathrm{~mA} ; 2 \theta) 5-60^{\circ}, 0.05^{\circ}$ step size and $3 \mathrm{~s}$ count time) and used for crystalline phase identification. The phases were identified by comparison with the data reported in the JCPDS (Joint Committee of Powder Diffraction Standards) database.

Results and Discussions: The physical properties and sorption coefficients of the hydrotalcites (HTCs) are summarized in Table 2. The sorption coefficients $\left(\log K_{d}\right)$ for iodide fall in a rather large range, from $10^{1}-10^{4}$. The iodide sorption does not appear to be significantly affected by the identity of the trivalent cation, except for $\mathrm{La}^{3+}$. This is not surprising as the ionic radius of six-coordinate lanthanum (1.032 $\AA$ ) is significantly larger than those of six-coordinate aluminum, chromium, iron and gallium ( $0.535 \AA$, $0.615 \AA, 0.645 \AA$, and $0.620 \AA$, respectively). Samples containing $\mathrm{Cu}^{2+}$ exhibited the highest sorption for iodide, followed by the samples containing $\mathrm{Co}^{2+}$ and $\mathrm{Ni}^{2+}$. These three metals are classified as "border region" elements of the hard/soft acceptor properties. The difference in sorption capacity between these three elements could be due to their electronic structures or that $\mathrm{Cu}^{2+}$ exhibits Jahn-Teller distortions. It was thought that the soft acceptor, $\mathrm{Pd}^{2+}$, would exhibit a higher iodide (soft) sorption capacity than the analogous $\mathrm{Ni}^{2+}$ compound, however, the sorption capacity of the palladium structure was about an order of magnitude smaller. This might be due to the larger ionic radius of sixcoordinate $\mathrm{Pd}^{2+}(0.86 \AA)$ compared to $\mathrm{Ni}^{2+}(0.690 \AA)$.

Nearly all of the HTCs' iodate sorption capacities were larger than the respective iodide sorption capacities, except for the $\mathrm{Mg} / \mathrm{Al}$ - HTC. Interestingly, the iodate sorption values for all but four HTCs $(\mathrm{Mg} / \mathrm{Al}, \mathrm{Pd} / \mathrm{Al}, \mathrm{Co} / \mathrm{La}$ and $\mathrm{Cu} / \mathrm{La})$ were $10^{3}$ or higher. The sorption capacities followed the same trends for iodate as for iodide. Several of the Co, Ni and Cu HTCs exhibited sorption capacities greater than $10^{2}$. Select samples were measured for their ability to sorb $\mathrm{TcO}_{4}{ }_{4}^{-}$. All of the samples tested exhibited higher values for $\mathrm{TcO}_{4}{ }^{-}$than for the $\mathrm{ReO}_{4}{ }^{-}$. The calcination times and sorption properties of the selected calcined HTCs are listed in Table 3. It can be seen that calcination of the samples decreased the sorption capacities for all of the anions tested. The length of calcination does not have a large effect on sorption values.

The HTC class of materials offers much promise for sequestering radioactive anions. Two HTC samples $(\mathrm{Cu} / \mathrm{Al}$ and $\mathrm{Cu} / \mathrm{Cr})$ exhibited sorption capacities of $10^{3}$ or greater for iodide, iodate and pertechnetate. Further studies are needed to determine the affects of composition, particle properties, radiation damage, the time of the HTC in the ionic test simulant, the composition of the test simulant, etc. on the ability of these materials to sorb radioactive anions. 
Table 2. Physical Properties and Sorption Coefficients of the Hydrotalcites $^{\mathrm{a}}$

\begin{tabular}{lccccc}
\hline $\begin{array}{c}\text { Targeted } \\
\text { Composition }\end{array}$ & $\begin{array}{c}\text { Structure } \\
\text { Type }^{b}\end{array}$ & $\begin{array}{c}\text { Log } \mathrm{K}_{\mathrm{d}} \\
\mathrm{I}^{-}\end{array}$ & $\begin{array}{c}\text { Log } \mathrm{K}_{\mathrm{d}} \\
\mathrm{IO}_{3}{ }^{-}\end{array}$ & $\begin{array}{c}\text { Log } \mathrm{K}_{\mathrm{d}} \\
\mathrm{ReO}_{4}{ }^{-}\end{array}$ & $\begin{array}{c}\text { Log } \mathrm{K}_{\mathrm{d}} \\
\mathrm{TcO}_{4}{ }^{-}\end{array}$ \\
\hline $\mathrm{Mg}_{6} \mathrm{Al}_{2}(\mathrm{OH})_{18}$ & $\mathrm{HTC}$ & 1.60 & 0.52 & 0.887 & - \\
$\mathrm{Co}_{6} \mathrm{Al}_{2}(\mathrm{OH})_{18}$ & $\mathrm{HTC}$ & 2.36 & 4.00 & 2.18 & - \\
$\mathrm{Ni}_{6} \mathrm{Al}_{2}(\mathrm{OH})_{18}$ & $\mathrm{HTC}$ & 2.51 & 4.70 & 2.55 & 3.40 \\
$\mathrm{Cu}_{6} \mathrm{Al}_{2}(\mathrm{OH})_{18}$ & $\mathrm{HTC}$ & 3.98 & $>4.66$ & 2.44 & 3.05 \\
$\mathrm{Zn}_{6} \mathrm{Al}_{2}(\mathrm{OH})_{18}$ & HTC & 2.26 & 3.82 & 2.00 & - \\
$\mathrm{Pd}_{6} \mathrm{Al}_{2}(\mathrm{OH})_{18}$ & HTC & 1.55 & 1.93 & 0.00 & - \\
$\mathrm{Cd}_{6} \mathrm{Al}_{2}(\mathrm{OH})_{18}$ & HTC & 1.20 & - & - & - \\
$\mathrm{Co}_{6} \mathrm{Cr}_{2}(\mathrm{OH})_{18}$ & HTC & 1.99 & 4.51 & 2.13 & - \\
$\mathrm{Ni}_{6} \mathrm{Cr}_{2}(\mathrm{OH})_{18}$ & HTC & 2.63 & $>4.66$ & 2.55 & 3.22 \\
$\mathrm{Cu}_{6} \mathrm{Cr}_{2}(\mathrm{OH})_{18}$ & HTC & 3.62 & $>4.66$ & 2.69 & 3.32 \\
$\mathrm{Co}_{6} \mathrm{Fe}_{2}(\mathrm{OH})_{18}$ & HTC & 1.53 & 3.89 & 2.02 & - \\
$\mathrm{Ni}_{6} \mathrm{Fe}_{2}(\mathrm{OH})_{18}$ & HTC & 2.15 & 4.78 & 2.16 & 3.20 \\
$\mathrm{Cu}_{6} \mathrm{Fe}_{2}(\mathrm{OH})_{18}$ & CHN & 2.89 & 4.22 & 1.90 & - \\
$\mathrm{Ni}_{6} \mathrm{Ga}_{2}(\mathrm{OH})_{18}$ & HTC & 2.02 & 3.79 & 2.14 & - \\
$\mathrm{Cu}_{6} \mathrm{Ga}_{2}(\mathrm{OH})_{18}$ & CHN & 3.22 & 4.72 & 2.18 & - \\
$\mathrm{Zn}_{6} \mathrm{Ga}_{2}(\mathrm{OH})_{18}$ & HTC & 1.36 & 3.19 & 1.47 & - \\
$\mathrm{Co}_{6} \mathrm{La}_{2}(\mathrm{OH})_{18}$ & HTC & 1.82 & 2.66 & 0.95 & - \\
$\mathrm{Ni}_{6} \mathrm{La}_{2}(\mathrm{OH})_{18}$ & HTC & 1.83 & 3.17 & 2.51 & 2.44 \\
\hline $\mathrm{Cu}_{6} \mathrm{La}_{2}(\mathrm{OH})_{18}$ & CHN & 1.62 & 1.77 & 0.26 & - \\
\hline $\mathrm{D}_{6}(-)$ & & & & \\
\hline
\end{tabular}

a. Dash (-) indicates no test was performed.

b. HTC indicates the conventional hydrotalcite structure and $\mathrm{CHN}$ indicates $\mathrm{Cu}_{2}\left(\mathrm{NO}_{3}\right)(\mathrm{OH})_{3}$.

Table 3. Physical Properties and Sorption Coefficients of the Calcined Hydrotalcites $^{\mathrm{a}}$

\begin{tabular}{|c|c|c|c|c|c|}
\hline $\begin{array}{c}\text { Targeted } \\
\text { Composition }\end{array}$ & $\begin{array}{c}\text { Calcination } \\
\text { Time } \\
\end{array}$ & $\begin{array}{c}\log K_{d} \\
I^{-}\end{array}$ & $\begin{array}{c}\log \mathrm{K}_{\mathrm{d}} \\
\mathrm{IO}_{3}^{-}\end{array}$ & $\begin{array}{c}\log \mathrm{K}_{\mathrm{d}} \\
\mathrm{ReO}_{4}^{-}\end{array}$ & $\begin{array}{c}\mathrm{Log} \mathrm{K}_{\mathrm{d}} \\
\mathrm{TcO}_{4}^{-} \\
\end{array}$ \\
\hline $\mathrm{Ni}_{6} \mathrm{Al}_{2}(\mathrm{OH})_{18}$ & 1 hour & - & 1.99 & 1.02 & - \\
\hline $\mathrm{Ni}_{6} \mathrm{Al}_{2}(\mathrm{OH})_{18}$ & 24 hours & 1.56 & 1.93 & 0.93 & - \\
\hline $\mathrm{Ni}_{6} \mathrm{Ga}_{2}(\mathrm{OH})_{18}$ & 1 hour & 0.89 & 2.42 & 1.23 & - \\
\hline $\mathrm{Ni}_{6} \mathrm{Ga}_{2}(\mathrm{OH})_{18}$ & 24 hours & 1.33 & 1.92 & 1.13 & - \\
\hline $\mathrm{Zn}_{6} \mathrm{Ga}_{2}(\mathrm{OH})_{18}$ & 1 hour & 1.36 & - & - & - \\
\hline $\mathrm{Zn}_{6} \mathrm{Ga}_{2}(\mathrm{OH})_{1}$ & 22 hours & 1.04 & - & - & - \\
\hline
\end{tabular}

\section{c. Layered Bismuth Hydroxides}

From the onset, developing anion getters based on bismuth seemed an attractive alternative given the considerable insolubility of many bismuth-oxide-anion combinations (e.g., those with sulfate, chloride, bromide, iodide, carbonate, nitrate, fluoride, iodate etc.). When alleged "hydrotalcites" 
(Tsuji et al., 2000) based on Bi-Mg-Zn-hydroxide formulations appeared it became apparent that the such materials might also have the high surface areas and positive surface charges required to selectively scavenge anions from solution. These materials were first evaluated as part of a DOE-Tank Focus Area effort (2001-2002) to find getters for use in HLW tank decommissioning. These results were encouraging enough (Appendix B) to warrant revisiting the topic in the context of finding getters for deployment in the YMP repository invert.

General Synthesis: Because of their historical affiliation with hydrotalcites, it is not surprising that the Bi-based materials are synthesized using methods similar to those used to prepare hydrotalcites. Typically, an acidified bismuth nitrate solution is prepared separately from that of the second metal salt. Care must also be exercised in the choice of the other metal salt since many anions (such as chloride, acetate, sulfate, carbonate etc.) will immediately react with bismuth and precipitate insoluble bismuth compounds that differ from the desired synthesis product. The fluids are then mixed and immediately titrated with sodium hydroxide until the $\mathrm{pH}$ stabilizes at about 9, though overshooting, even up to $\mathrm{pH} 12$, does not appear to make any difference. Traditional hydrotalcite preparation methods may also employ sodium carbonate rather than sodium hydroxide to raise the $\mathrm{pH}$. However, the bismuth oxy-carbonate salt which then forms has little affinity for scavenging the radionuclides in question (iodide Kd of just 16). As the $\mathrm{pH}$ increases a thick, white, pasty slurry forms immediately, which is then cured in the synthesis fluid at about $90^{\circ} \mathrm{C}$ oven for times ranging from overnight to over the weekend. (For the record, no significance could be ascribed to curing times, or to whether the process was even carried out.) However, since a successful getter in the YMP repository environment will have to withstand elevated temperatures, it seemed a sensible precaution to incorporate a heating step into the synthesis procedure.) The residual salt solution is then washed out and the residue dried (either at room temperature or in a drying oven) producing a cohesive mass of material that can be ground to give the very fine powder used in batch $K_{d}$ testing. Appendix A (Table A-4) gives additional details on the synthesis of materials used in this study while Appendix B provides some details on materials from the previous TFA study.

Performance of archived Bi-based iodine getters: The current study was initiated by reexamining the performance of the archived getters developed earlier under TFA sponsorship. Particular concerns were whether the passage of time (and possible aging of materials), or the use of a different test fluid (e.g., J-13 surrogate vs. 1\% to 5\% DSSF-7 HLW tank simulant fluid see Appendix B, Table B-1 for composition) would negate the promise evident in the earlier study. Secondary objectives were to: (a) extend the database on their performance to include the sorption of iodate as well as iodide, and (b) assess if these materials had also retained some ability scavenge $\mathrm{ReO}_{4}^{-}$.

After aging for more than a year, these materials did, indeed, retain their ability to scavenge both iodide and $\mathrm{ReO}_{4}{ }^{-}$, though in the latter case the performance was insufficient to meet the $10^{3} \mathrm{~K}_{\mathrm{d}}$ criteria that defines a "useful" getter. We also established that these aged materials were good iodate getters - occasionally performing at levels that exceeded their ability to scavenge iodide (Table 4). 
In some cases arsenate sorption was also assessed as a "probe” for a getter's propensity for forming inner sphere surface sorption complexes, and because treating drinking water is currently of great topical interest. Generally, these materials proved to be very effective arsenic scavengers with "batch $K_{d}$ " values in the range of $10^{5}-10^{6}$. This performance is significantly better than what was measured for As in the earlier (TFA-sponsored) tests (compare Table 7, 8, and 9 with Appendix B, Table B-4). This improvement presumably reflects a higher $\mathrm{pH}$ present in the 1\%-5\% DSSF-7 fluid as compared to that of the "J-13 surrogate" - which is the trend which might be expected with changing $\mathrm{pH}$, where an anionic constituent was scavenged by a surface complexation process (Davies and Kent, 1990).

Table 4. Batch “Kd's” for previously synthesized materials in a J-13 simulant (NT = not tested)

$0.25 \mathrm{~g}$ solid sample to $25 \mathrm{ml} \mathrm{J}-13$ simulant, shaken for 24 - 48 hours. Sample designation with occasionally $\mathrm{X}$-ray data and chemistry See appendix 2 for additional details on materials.

HT-O

HT-1, $\mathrm{Zn}>\mathrm{Sn}+2 \mathrm{Al}$, SO4, HT peaks broad but well defined HT-2, $\mathrm{Zn}>\mathrm{Sn}+2 \mathrm{Al}$, SO4, HT peaks broad but well defined HT-3, Zn-Bi, SO4, Almost no HT peaks

$\mathrm{HT}-4, \mathrm{Mg}-\mathrm{Bi}, \mathrm{CO} 3$, Almost no HT peaks

HT-5 (fines), Zn-Al, SO4, HT peaks well developed

HT-6, Mg-Bi, SO4, Almost no HT peaks

$\mathrm{HT}-7, \mathrm{Zn}-\mathrm{Bi}, \mathrm{Ac}(\mathrm{Ac}=$ =Acetate $)$, HT peaks broad but prominent

HT-8, ZnAl, Ac, HT peaks broad but prominent

HT-9, MgAl, Ac, well crystallized HT

$\mathrm{HT}-10, \mathrm{ZnBi}, \mathrm{Ac}, \mathrm{HT}$ peaks broad but prominent

$\mathrm{HT}-11$ (dried $90-97^{\circ} \mathrm{C}$ ), $\mathrm{Mg}>\mathrm{CuBi}, \mathrm{Ac}$, well crystallized $\mathrm{HT}$

HT-11 (lime green), $\mathrm{Zn}>\mathrm{CuBi}, \mathrm{Ac}$, multiple broad HT peaks

HT-12 (low temp drying), $\mathrm{Mg}>\mathrm{Cu}, \mathrm{Bi}, \mathrm{Ac}$, well crystallized HT

HT-14 (batch 1), Mg Al, Ac, poorly crystallized HT

$\mathrm{HT}-15, \mathrm{Zn}>\mathrm{Cu}, \mathrm{Sn}+2 \mathrm{La}>\mathrm{Sn}+4$, Ac, Small broad well defined HT

$\mathrm{HT}-16, \mathrm{Mg}>\mathrm{Cu}, \mathrm{Sn}+2 \mathrm{La}>\mathrm{Sn}+4, \mathrm{Ac}$, poorly crystalline HT

$\mathrm{HT}-17 / 18$ ? $\mathrm{Zn}>\mathrm{Sn}+2$, La, Ac (NA)

$\mathrm{HT}-17, \mathrm{Zn}>\mathrm{Sn}+2 \mathrm{La}, \mathrm{Ac}$, no HT, $\mathrm{ZnO}$ and $\mathrm{Sn} 6 \mathrm{O} 4(\mathrm{OH}) 4$

HT-18, Mg >Sn+2La, Ac, no HT, good Sn6O4(OH)4 poor

$\mathrm{Mg} 2 \mathrm{La} 2 \mathrm{SnO} 7$

HT-19, $\mathrm{Mg}>\mathrm{Cu}, \mathrm{Sn}+2 \mathrm{Al}>\mathrm{Sn}+4, \mathrm{Ac}$, small broad HT peaks

$\mathrm{HT}-20 \mathrm{Zn}>\mathrm{Cu}, \mathrm{Sn}+2 \mathrm{Al}>\mathrm{Sn}+4, \mathrm{Ac}$, small broad HT peaks

HT-20 (Split of Apricot colored precipitate)

HT-20 (blue, settled on top)

HT-21 (split), Mg >Cu, Sn+2Al>Sn+4, Ac, small broad HT peaks

HT-21 (settled on top)

HT-22 (Turquoise colored from top of batch)

$\mathrm{HT}-22$ (split), $\mathrm{Zn}>\mathrm{Cu}$ and $\mathrm{Al}>\mathrm{Sn}$

HT -22 (settled on top)

HT -23 (Hot split)

NT $=$ not tested

A $\log (\mathrm{Kd})$ of about 4.2 means the analytic instrumentation is about at the lower limit of its detection.

$\begin{array}{ccc}\mathrm{I}^{-} & \mathrm{IO}_{3}{ }^{-} & \mathrm{ReO}_{4}^{-} \\ \mathrm{Log}(\mathrm{Kd}) & \mathrm{Log}(\mathrm{Kd}) \\ \mathrm{NT} & 1.6 & \mathrm{Kd}<10 \\ \mathrm{NT} & 1.6 & \mathrm{Kd}<10 \\ \mathrm{NT} & \mathrm{Kd}<25 & \mathrm{Kd}<10 \\ 2.3,2.4 & 2.5,2.5 & \mathrm{Kd}<10 \\ 1.2 & 1.4,1.1 & \mathrm{Kd}<10 \\ \mathrm{NT} & \mathrm{Kd}<25 & 1.2 \\ \mathrm{Kd}<10 & 1.6 & \mathrm{Kd}<10 \\ 3.7,3.8 & 3.3 & 2.1 \\ \mathrm{NT} & 2.9 & 2.1 \\ \mathrm{NT} & 3.6 & 1.9,2.0 \\ 3.7,4.0 & 2.3 & 1.4 \\ 1.7 & 2.8 & 1.8 \\ 3.9,3.9 & 3.4 & 1.5 \\ 1.7 & 2.8,1.9 & 1.8 \\ \mathrm{NT} & 3.2 & 2 \\ 3.1 & 2.9,4.0 & 1.7,2.5 \\ 1.5 & 2.8 & 1.4 \\ \mathrm{Kd}<10 & \mathrm{NT} & \mathrm{NT} \\ \mathrm{Kd}<10 & 3 & 1.9 \\ \mathrm{Kd}<10 & 1.8 & 2.3 \\ \mathrm{NT} & 3.4,3.3 & 2.2,2.3 \\ 3.1 & 4 & 2.4,2.5 \\ 2.9,3.2 & 3.9 & 2.5,2.5 \\ 1.5 & 2.5 & 1.4 \\ \mathrm{NT} & 3 & 2.1,2.0 \\ \mathrm{NT} & 1.6 & 1.3 \\ \mathrm{NT} & 3.8 & 2.3,2.3 \\ \mathrm{NT} & 3.8 & 2.4,2.4 \\ \mathrm{NT} & 2.4 & 1.3 \\ \mathrm{NT} & 1.5 & 0.4\end{array}$


Newly Developed Bi-based Iodine Getters (Round 1): Studies on the archived materials clearly demonstrated that Bi-based materials were promising getters. However, a number of unanswered questions remained:

(a) would a second synthesis also result in successful getters or were the initial result some sort of an experimental fluke;

(b) does the presence of a second metal have a strong impact on the performance of such materials;

(c) how sensitive is the performance with respect to changes in test solution $\mathrm{pH}$;

(d) what is the maximum loading of the secondary metal that could be tolerated;

(e) how important is the anion mix (e.g. anions needed to counterbalance the metals in the synthesis) in the original synthesis?

To address these questions, additional batches of materials were synthesized (Appendix A) and tested using the familiar "batch $\mathrm{Kd}$ " methodology and the " $\mathrm{J}-13$ simulant" solution that was doped with ppm levels of various radionuclide surrogates (Table 5, and Appendix A).

Table 5: Synthesis details and Kd results for various Round 1 - Bi-based getters

(The balance of these tests would have been performed with what would turn out to be a relatively high solid:liquid ratio; approximately $0.1 \mathrm{~g}$ of getter in $25 \mathrm{ml}$ of $\mathrm{J}-13$ simulant solution. Colors group result from different batches of analyses.)

\begin{tabular}{|c|c|c|c|c|c|c|c|}
\hline $\begin{array}{l}\text { Sample } \\
\text { Desiganation }\end{array}$ & $\begin{array}{l}\text { \# grams } \\
\mathrm{Bi}(\mathrm{NO}) 3-\end{array}$ & $\begin{array}{l}\text { Other } \\
\text { Salts }\end{array}$ & $\begin{array}{l}\text { grams } \\
\text { salts }\end{array}$ & $\begin{array}{l}\text { Base } \\
\text { Used* }\end{array}$ & $\begin{array}{l}\text { I- } \\
\log (K d)\end{array}$ & $\begin{array}{l}\text { IO3- } \\
\log (K d)\end{array}$ & $\begin{array}{l}\text { ReO4- } \\
\text { Log(Kd) }\end{array}$ \\
\hline & \multicolumn{7}{|l|}{ Pentahydrate } \\
\hline P5-J & \multirow{2}{*}{$\begin{array}{l}8.13 \\
8.30\end{array}$} & $3 \mathrm{Ni}(\mathrm{NO} 3) 2 ¥$ & 15.15 & $5 \mathrm{Ni}(\mathrm{OH}) 2$ & $2.9,3.4,2.90,2.8$ & 3.4 & $1.4,1.2$ \\
\hline P5-K & & $\mathrm{Zn}(\mathrm{NO}) 2 ¥$ & 20.97 & $\mathrm{ZnO}$ & $3.8,4.0,3.6,3.5$ & 4.9 & 2.4 \\
\hline P5-L & 8.12 & $\mathrm{Zn}(\mathrm{NO} 3) 2 ¥$ & 1.54 & $4 \mathrm{NH} 4 \mathrm{OH}$ & $5.2,4.0,3.8,4.1$ & 4.9 & $3.8,3.8$ \\
\hline Pepto Bismol - dried & $\mathrm{N} / \mathrm{A}$ & $\mathrm{N} / \mathrm{A}$ & $\mathrm{N} / \mathrm{A}$ & N/A & 3.0 & 2.7 & 2.1 \\
\hline Bi-subcarbonate & $N / A$ & N/A & N/A & N/A & 2 & 2.0 & 1.0 \\
\hline $\mathrm{Bi} 2 \mathrm{O} 3$ untreated & N/A & $\mathrm{N} / \mathrm{A}$ & $\mathrm{N} / \mathrm{A}$ & $\mathrm{N} / \mathrm{A}$ & 3 & 1.7 & $\mathrm{Kd}<10$ \\
\hline P5-A & \multicolumn{2}{|c|}{$\mathrm{Bi2O} 3$ in fused LiNO } & $\mathrm{OO}$ & $\mathrm{N} / \mathrm{A}$ & $3.6,3.5$ & $2.3,2.3$ & $1.3,1.2$ \\
\hline P5-B \& C & \multicolumn{2}{|c|}{ 8.25 LiNO3 } & 10.84 & $4 \mathrm{NH} 4 \mathrm{OH}$ & $4.26,4.4,4.4$ & 4.2 & $3.8,3.8$ \\
\hline P5-D & \multicolumn{2}{|c|}{ 8.31 LiNO3 } & 0 & $\mathrm{NH} 4 \mathrm{OH}$ & $4.1,3.9,3.9,4.2$ & 4.6 & $2.3,2.3$ \\
\hline $\mathrm{P} 5-\mathrm{H}$ & \multicolumn{2}{|c|}{$8.25 \mathrm{KNO} 3$} & 15.52 & $\mathrm{KOH}$ & $3.7,3.8,3.4,4.0$ & 3.5 & $2.1,2.2$ \\
\hline P5-I & \multicolumn{2}{|c|}{ 8.17 NaNO3 } & \multicolumn{2}{|c|}{$13.35 \mathrm{NaOH}$} & $3.3,3.7$ & 2.5 & 0.9 \\
\hline P9-1 & \multicolumn{2}{|c|}{ 8.37 LiNO3 } & 1.08 & $\mathrm{Na}(\mathrm{OH})$ & 3.8 & NT & NT \\
\hline P9-2 & 8.29 & KNO3 & 15.65 & $\mathrm{Na}(\mathrm{OH})$ & 3.8 & NT & NT \\
\hline P9-3 & 8.21 & KNO3 & 1.56 & $\mathrm{Na}(\mathrm{OH})$ & 3.9 & NT & NT \\
\hline P9-4 & 8.27 & $7 \mathrm{NaNO} 3$ & 13.36 & $\mathrm{Na}(\mathrm{OH})$ & 4.0 & NT & NT \\
\hline P9-5 & 8.23 & $3 \mathrm{NaNO} 3$ & 1.38 & $\mathrm{Na}(\mathrm{OH})$ & 3.8 & NT & NT \\
\hline \multicolumn{8}{|c|}{$\begin{array}{l}\text { \# The bismuth ntirate hydrate was dissolved in roughly } 5 \mathrm{~g} \text { concentrated HNO3 mixed with } 25 \mathrm{ml} \text { DI H2O } \\
\text { * Titrated to roughly } \mathrm{pH} 9.5\end{array}$} \\
\hline$¥$ Hexahydrate salt & & & & & & NTT - N & sted \\
\hline
\end{tabular}


One set of the new materials (P5-J, K, L) resembled the old mixes in that the synthesis fluid contained both a $\mathrm{M}^{+2}$ metal and bismuth. Since among the TFA-sponsored samples the performance of $\mathrm{Mg}^{+2}$ - based materials was inferior to that of $\mathrm{Zn}$ based materials, the decision was made to substitute a different divalent metal, $\mathrm{Ni}^{+2}$. The results from these tests confirmed the robust nature of the synthesis since, with minimal care; it was again possible to prepare materials that were excellent scavengers for both iodide and iodate. In addition, this time some materials (P5- B,C and L) performed "acceptably" for $\mathrm{ReO}_{4}{ }^{-}$removal.

The possibility of gaining insights into the impact of the second metal, as well as the type of base used to neutralize the initial metal mix, was also built into this early experimental matrix. Thus, the relative performance of $\mathrm{Zn}$ and Ni-based materials were assessed alongside of a variety of combinations where the second metal was a monovalent alkali cation ( $\mathrm{Li}, \mathrm{K}, \mathrm{Na})$. The concept arose out of the observation that if $\mathrm{Al}(\mathrm{OH})_{3}$ - also a layered lattice - is placed in a concentrated lithium salt solution some lithium ions diffuse into the vacant octahedral sites in the $\mathrm{Al}(\mathrm{OH})_{3}$ lattice, creating an anion exchange medium (Devyatkina et al., 1983; Lei et al., 2000). Given that the size of the sites in a predominantly Bi-hydroxide lattice would not necessarily be the same as those in aluminum hydroxide, it seemed reasonable to try other monovalent cations as well hence $\mathrm{Na}^{+}$and $\mathrm{K}^{+}$; ammonium was also added by default since large amounts of ammonium hydroxide were occasionally employed to neutralize the nitric acid required to initially keep the bismuth in solution.

The results of these substitutions were not particularly dramatic, at least with regard to the ability of the materials to scavenge iodide. Most of the iodide $\log \left(K_{d}\right)$ values still fell between 3 and 4 and about the only clear trend is that the Ni-based material is not quite as good as the others. The picture with regard to iodate and perrhenate scavenging is more interesting. $\log \left(\mathrm{K}_{\mathrm{d}}\right)$ values for iodate range from about 2.5 to 4.9, a factor of 250 difference in performance. For perrhenate, the spread was even larger with $\log \left(\mathrm{K}_{\mathrm{d}}\right)$ values from 0.9 to 3.8 - a factor of almost 800 difference in performance. The highest $\mathrm{ReO}_{4}{ }^{-} \mathrm{K}_{\mathrm{d}}$ values were sufficiently anomalous to warrant some follow-up experimentation employing actual $\mathrm{TcO}_{4}{ }^{-}$. In a $\mathrm{J}-13$ solution spiked with tracer levels of pertechnetate the $\mathrm{K}_{\mathrm{d}}$ was measured as 7,350 for the P5-B\&C material, while in a solution spiked initially to a level of $12.8 \mathrm{ppm}$ Tc $\left(1.3 \times 10^{-4}\right.$ molar $)$ the $\mathrm{K}_{\mathrm{d}}$ still had a surprisingly high value of 338. These results directly support the concept of using $\mathrm{ReO}_{4}{ }^{-}$as a surrogate for $\mathrm{TcO}_{4}{ }^{-}$, at least as a qualitative technique for identifying promising candidate Tc-getters. A quantitative correspondence between getter responses to the two anions remains to be established.

Finally, a few scoping tests were performed on materials that were commercially available to assess whether just any bismuth compound was likely to work (Pepto-Bismol (dried) - bismuth subsilicate, from the drug store, and reagent grade bismuth oxide and subcarbonate). Nothing dramatic showed up here but is may be significant that treating the $\mathrm{Bi}_{2} \mathrm{O}_{3}$ in molten $\mathrm{LiNO}_{3}$ did enhance the overall scavenging ability of the residue.

Samples prepared independently by the second author (J.D.P. rather than J.L.K.) also show similar results (Table 6), again confirming that the synthesis is, indeed, robust. It is also evident that the bismuth oxyhalides have significantly smaller sorption capacities than do the bismuth oxides (Table 6). 
Table 6. Sorption Coefficients of Bismuth Compounds

\begin{tabular}{lccc}
\hline \multicolumn{1}{c}{ Structures Identified By XRD } & $\begin{array}{c}\text { Log } \mathrm{K}_{\mathrm{d}} \\
\mathrm{I}^{-}\end{array}$ & $\begin{array}{c}\text { Log } \mathrm{K}_{\mathrm{d}} \\
\mathrm{IO}_{3}^{-}\end{array}$ & $\begin{array}{c}\text { Log } \mathrm{K}_{\mathrm{d}} \\
\mathrm{ReO}_{4}^{-}\end{array}$ \\
\hline $\mathrm{Mg}(\mathrm{OH})_{2}+\mathrm{Bi}_{\mathrm{x}} \mathrm{O}_{\mathrm{y}}$ & 3.18 & 3.42 & 2.75 \\
$\mathrm{Co}_{5}\left(\mathrm{O}_{9.48} \mathrm{H}_{8.52}\right) \mathrm{NO}_{3}+\mathrm{Bi}_{\mathrm{x}} \mathrm{O}_{\mathrm{y}}$ & 2.75 & 4.09 & 3.56 \\
$\mathrm{NiO}(\mathrm{OH})+\mathrm{Bi}_{\mathrm{x}} \mathrm{O}_{\mathrm{y}}$ & 2.44 & 3.46 & 3.31 \\
$\mathrm{ZnO}+\mathrm{BiOCl}$ & 1.74 & 1.99 & 0.96 \\
$\mathrm{ZnO}+\mathrm{Bi}_{\mathrm{x}} \mathrm{O}_{\mathrm{y}}$ & 3.78 & 3.94 & 3.71 \\
\hline $\mathrm{Cu}_{4}\left(\mathrm{NO}_{3}\right)_{2}(\mathrm{OH})_{6}+\mathrm{Bi}_{6}\left(\mathrm{NO}_{3}\right)_{4}(\mathrm{OH})_{2} \mathrm{O}_{6} 2 \mathrm{H}_{2} \mathrm{O}$ & 4.06 & 3.36 & 2.18 \\
\hline
\end{tabular}

To summarize, based on these studies it appears that Bi-based getter materials have the following characteristics:

1. The synthesis is relatively robust and reproducible;

2. At least for iodide, the second metal in the mix did not have a large effect on performance;

3. Materials were identified that scavenged iodate as effectively as they scavenged iodide;

4. Although not the direct objective of this research, there are indications that these materials may also be effective at scavenging perrhenate (and hence technetium);

5. The nature of the alkali metal base, as well as high initial alkali metal concentrations in the synthesis fluid had little impact on the ability of getters to scavenge iodide, but did impact scavenging ability of the getter toward other anions.

Follow-On Studies (Round 2): The large spread in Kd values for iodate and perrhenate, and the small, though significant, difference between the performance of the $\mathrm{Zn}$ and Ni based materials even for iodide, prompted additional research into mixes rich in divalent and trivalent metals. Toward this end a variety of multi-metal mixes were prepared in pairs. Mixes designated "-1" (Table 7) were fabricated from a synthesis solution containing a 1:10 molar ratio of metal to bismuth while those designated "-2" had equal amounts of the second metal and bismuth in the synthesis solution prior to the neutralization step.

It was obvious at the onset that in most cases much of the second metal was not incorporated into the precipitates. This follows from the fact that for the highly colored ions the post-precipitation solution remained colored, while the precipitate (after being washed appropriately) was white. Those solids with obvious coloration included mixes with iron (brown), manganese (black), and chromium (III - green). However, even in these cases, the co-precipitation of a second hydroxide is a more likely explanation than formation of a mixed-metal hydroxide material and only small amounts would actually be needed to color the mix.

Even when placed on a shaker table, the solids in the first $\mathrm{K}_{\mathrm{d}}$ runs did not appear to stay suspended very well. A second set of experiments was, therefore, performed after the materials had been ground to a fine powder. The liquid:solid ratio was also decreased by a factor of four since in the first round of testing some materials had removed essentially all of the radionuclide 
surrogate (leaving dissolved concentrations almost at the detection limit of the ICP-MS). Quite surprisingly, the $\mathrm{K}_{\mathrm{d}}$ values from the second pass were significant less, in spite of the grinding, which should have made more surfaces available (Fig. 2 and Table 7).

This odd behavior apparently arises because by decreasing the solid:liquid ratio we (inadvertently) entered the realm where the sorption capacity of the solids was approaching saturation. This explanation is consistent with the observation that the overall iodide loading was similar in the pre and post grinding experiments even though the $K_{d}$ values differed significantly. For, example, for iodide, the $K_{d}$ values in most cases differed by at least a factor of ten (an average difference factor is 13.3), while the loadings differed by significantly smaller factors (an average of 2.7). Thus, in addition to providing $K_{d}$ values for iodide sorption at low iodine concentrations, these results also, fortuitously, provide rough estimates of material loading capacities in a concentration range relevant to assessing performance in YMP-related environments..

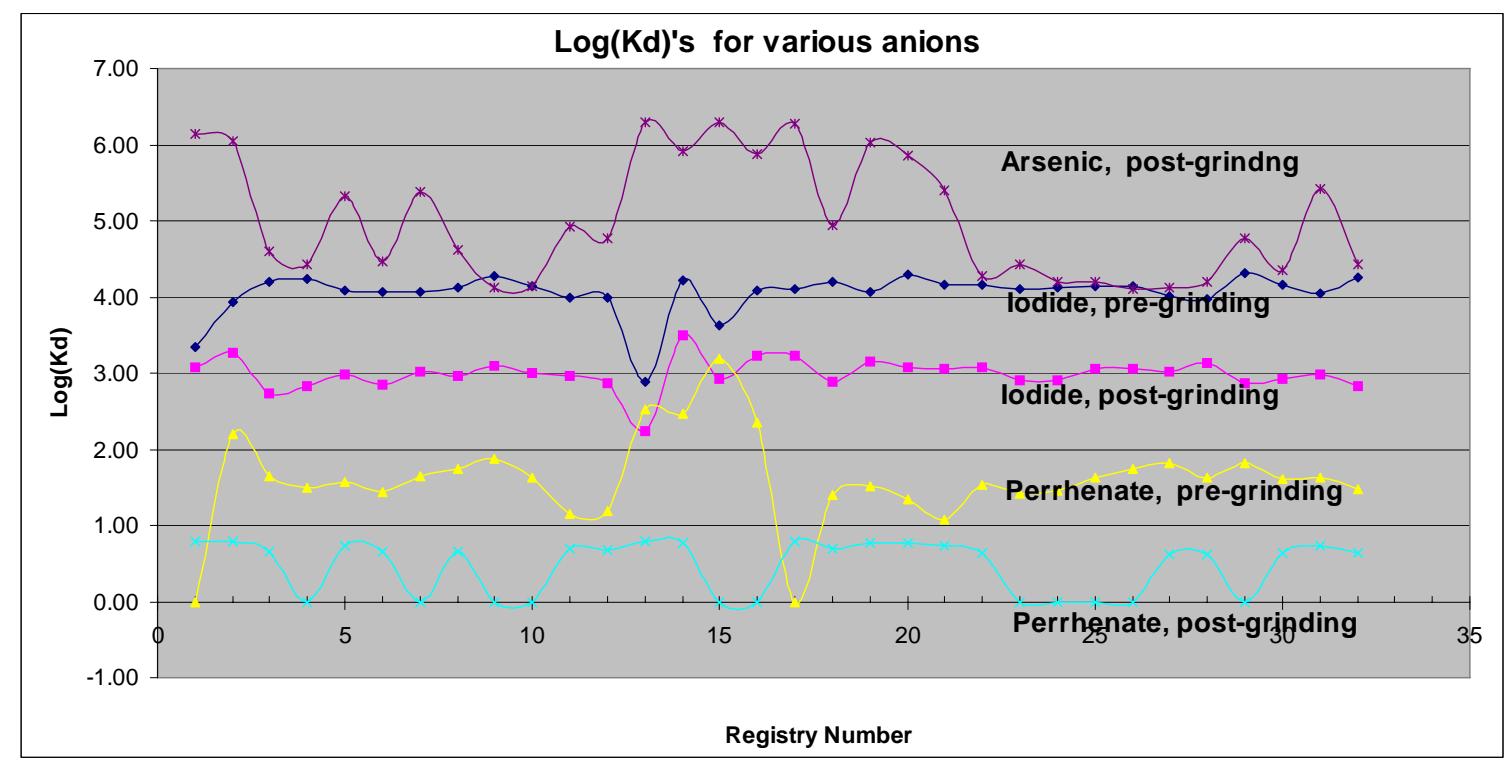

Fig. 2. Comparative behavior before and after grinding iodide, perrhenate and arsenate. (post-grinding only, pre grinding analyses were mostly non-detects with the implication of values greater also than those for the post-grinding, though by how much cannot be quantified). Registry numbers provide sample identification; see Table 7.

A second odd behavior noted in the course of these experiments was that the $\mathrm{pH}$ of the equilibrated $\mathrm{K}_{\mathrm{d}}$ experiments was distinctly acidic, in spite of the fact that the recipe used for making these materials generally involved titrating the synthesis fluid to a distinctly basic $\mathrm{pH}$ and then aging the precipitate overnight in this fluid. Studies performed early in the program (Fig. 3) had indicated that Kd values were higher in more acidic solutions - but it was unclear how large the decrease would be in mildly basic YMP-related groundwaters, and whether this behavior applied to iodate and perrhenate as well as iodide. 
Table 7: Kd values before and after grinding

\begin{tabular}{|c|c|c|c|c|c|c|c|c|c|}
\hline $\begin{array}{l}\text { Registry } \\
\text { Number }\end{array}$ & & $\begin{array}{l}\text { Before } \\
\text { Grinding } \\
\text { lodide } \\
\text { Log Kd }\end{array}$ & $\begin{array}{l}\mathrm{pH} \text { of } \\
\text { "Before" } \\
\text { Kd Expt. } \\
\text { Fluids }\end{array}$ & $\begin{array}{l}\text { After } \\
\text { Grinding } \\
\text { lodide } \\
\text { Log Kd }\end{array}$ & $\begin{array}{l}\mathrm{Kd} / \mathrm{Kd} \\
\text { Pre/post }\end{array}$ & $\begin{array}{l}\text { Relative } \\
\text { Loading } \\
\text { Post/pre }\end{array}$ & $\begin{array}{l}\text { Before } \\
\text { Grinding } \\
\text { ReO4- } \\
\text { Log Kd }\end{array}$ & $\begin{array}{l}\text { After } \\
\text { Grinding } \\
\text { ReO4- } \\
\text { Log Kd }\end{array}$ & $\begin{array}{l}\text { After } \\
\text { Grinding } \\
\text { As } \\
\text { Log Kd }\end{array}$ \\
\hline 1 & FeAc-1 & 3.34 & 5.74 & 3.07 & 1.86 & 2.95 & NT & 1.98 & 6.14 \\
\hline 2 & $\mathrm{Fe} \| \mathrm{Ac} 1$ & 3.93 & 5.682 & 3.26 & 4.68 & 3.09 & 2.20 & 1.58 & 6.05 \\
\hline 3 & NiAc-1 & 4.19 & 5.38 & 2.73 & 28.84 & 2.88 & 1.65 & 1.73 & 4.60 \\
\hline 4 & $\mathrm{NiAc}-2$ & 4.24 & 5.143 & 2.82 & 26.30 & 2.51 & 1.50 & NS & 4.44 \\
\hline 5 & BaNO3 1 & 4.09 & 4.786 & 2.99 & 12.59 & 2.63 & 1.58 & 1.69 & 5.32 \\
\hline 6 & BaNO3 2 & 4.07 & 5.111 & 2.85 & 16.60 & 2.51 & 1.43 & 1.32 & 4.47 \\
\hline 7 & CuAc 1 & 4.06 & 4.861 & 3.03 & 10.72 & 2.75 & 1.64 & NS & 5.38 \\
\hline 8 & CuAc 2 & 4.12 & 5.364 & 2.97 & 14.13 & 2.75 & 1.75 & 1.04 & 4.61 \\
\hline 9 & MgNO3 1 & 4.27 & 5.523 & 3.09 & 15.14 & 2.95 & 1.88 & NS & 4.13 \\
\hline 10 & MgNO3 2 & 4.14 & 5.3 & 3.00 & 13.80 & 2.69 & 1.62 & NS & 4.15 \\
\hline 11 & ZnAc 1 & 4.00 & 4.918 & 2.96 & 10.96 & 2.29 & 1.15 & 2.13 & 4.92 \\
\hline 12 & ZnAc 2 & 3.99 & 5.714 & 2.87 & 13.18 & 2.19 & 1.19 & 1.66 & 4.78 \\
\hline 13 & CrNO3 1 & 2.89 & 5.311 & 2.24 & 4.47 & 2.57 & 2.53 & 1.68 & 6.29 \\
\hline 14 & CrNO3 2 & 4.22 & 5.86 & 3.50 & 5.25 & 3.47 & 2.47 & 1.81 & 5.91 \\
\hline 15 & ZrNO3 1 & 3.63 & 5.033 & 2.92 & 5.13 & 2.69 & 3.19 & NS & 6.29 \\
\hline 16 & ZrNO3 2 & 4.08 & 5.555 & 3.24 & 6.92 & 3.02 & 2.36 & NS & 5.88 \\
\hline 17 & LaNO3 1 & 4.10 & 6.336 & 3.23 & 7.41 & 3.02 & $\log (K d)>5$ & 2.01 & 6.27 \\
\hline 18 & LaNO3 2 & 4.20 & 5.078 & 2.88 & 20.89 & 2.45 & 1.39 & 0.82 & 4.95 \\
\hline 19 & Mn II Ac 1 & 4.06 & 5.275 & 3.16 & 7.94 & 2.75 & 1.51 & 1.96 & 6.03 \\
\hline 20 & Mn II Ac 2 & 4.29 & 5.465 & 3.08 & 16.22 & 2.75 & 1.35 & 2.19 & 5.86 \\
\hline 21 & ZnNO3 1 & 4.16 & 4.933 & 3.05 & 12.88 & 2.51 & 1.07 & 1.71 & 5.40 \\
\hline 22 & ZnNO3 2 & 4.17 & 5.104 & 3.08 & 12.30 & 2.75 & 1.54 & 0.32 & 4.28 \\
\hline 23 & $\operatorname{MgAc} 1$ & 4.11 & 5.496 & 2.90 & 16.22 & 2.88 & 1.42 & NS & 4.43 \\
\hline 24 & $\operatorname{MgAc} 2$ & 4.13 & 5.395 & 2.90 & 16.98 & 2.75 & 1.46 & NS & 4.20 \\
\hline 25 & CaNO3 1 & 4.13 & 5.639 & 3.05 & 12.02 & 2.88 & 1.63 & NS & 4.20 \\
\hline 26 & CaNO3 2 & 4.15 & 5.525 & 3.06 & 12.30 & 2.82 & 1.73 & NS & 4.11 \\
\hline 27 & SrNO3 1 & 4.01 & 5.734 & 3.02 & 9.77 & 2.69 & 1.82 & 1.88 & 4.12 \\
\hline 28 & SrNO3 2 & 3.97 & 5.857 & 3.13 & 6.92 & 2.82 & 1.63 & 2.02 & 4.20 \\
\hline 29 & NiNO3 1 & 4.31 & 5.467 & 2.87 & 27.54 & 2.45 & 1.83 & NS & 4.78 \\
\hline 30 & NiNO3 2 & 4.15 & 5.452 & 2.93 & 16.60 & 2.69 & 1.61 & 1.49 & 4.35 \\
\hline 31 & CuNO3 1 & 4.04 & 5.302 & 2.99 & 11.22 & 3.02 & 1.63 & 0.93 & 5.42 \\
\hline 32 & CuNO3 2 & 4.26 & $\begin{array}{r}4.759 \\
\text { Averag }\end{array}$ & ye is 2.82 & $\begin{array}{l}27.54 \\
13.29\end{array}$ & $\begin{array}{l}2.63 \\
2.75\end{array}$ & 1.47 & 0.89 & 4.44 \\
\hline
\end{tabular}




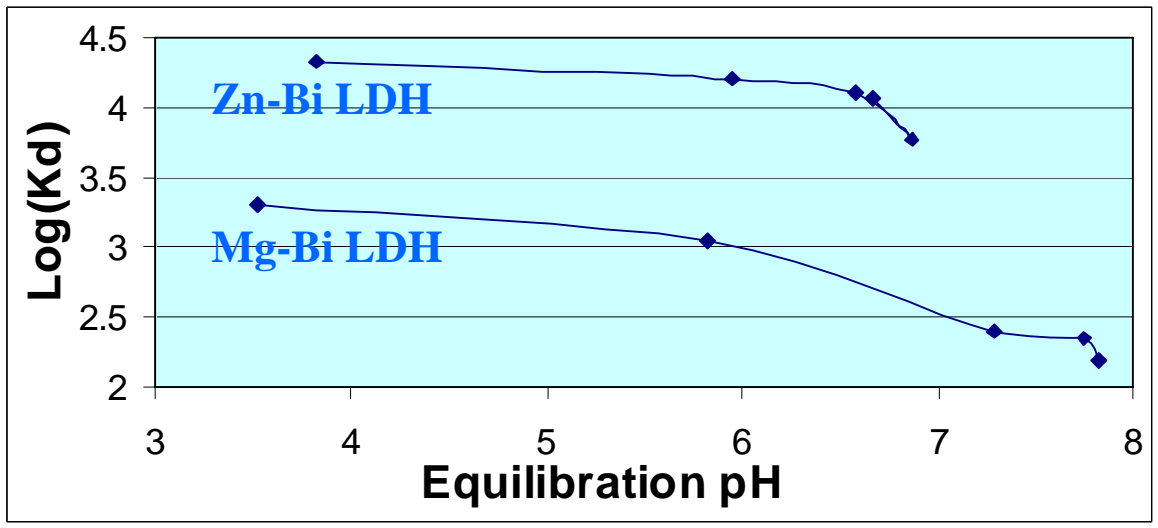

Fig. 3. Iodide Log Kd vs pH behavior for two mixed-metal layered double hydroxides synthesized early in the program.

Several mechanisms may be involved in scavenging iodide (and other radionuclides). If the bismuth hydroxide sheets in the lattice have a residual positive charge then an anion must reside on the surface of the sheets to maintain overall electrical neutrality of the mineral - but the nature of the anion is not particularly important. This is the setting where traditional kinds of anion exchange reactions may occur, and $\mathrm{pH}$ has a minimal impact on the process.

Alternatively, radionuclides may also be scavenged by a process (actually a collection of processes) broadly termed "surface complexation" (Davies and Kent, 1990). This occurs where incompletely bonded atoms left exposed on mineral surfaces interact with ions from the surrounding solutions. Typically, the hydrogen ion is strongly bonded to such surfaces so the overall surface charge (as well as the ability of the surface to exchange anions or cations) depends strongly on the $\mathrm{pH}$ of the surrounding fluid. In strongly acidic solutions a net positive surface charge develops and materials become good anion scavengers, while the opposite happens in basic solutions. It is this implicitly strong $\mathrm{pH}$ dependence that is of concern. Given the acidic nature of the final $\mathrm{K}_{\mathrm{d}}$ solutions it is quite possibly that the generally auspicious high Kd values observed might not be representative of performance in the mildly basic indigenous YMP-related groundwaters.

To resolve this uncertainty several samples were selected for more detailed studies. In the first round of tests (Table 8, Fig. 4) the J-13 surrogate was spiked with iodide, perrhenate, and arsenate. A second set of tests was done with iodate to complete the experimental matrix (Table 9 and Fig. 5).

For iodide and perrhenate a strong $\mathrm{pH}$ dependence is not apparent, except for the two extreme points for Fe and $\mathrm{Zr}$. Thus, it is reasonable to surmise that anion exchange (onto charged metal hydroxide sheets) dominates over a surface complexation mechanism. For the more strongly held arsenate, however, there is evidence for a mixture of scavenging mechanisms in some cases. The NiAc-1 samples still appears to be dominated by a purely anion exchange mechanism. However, the BaNO3-1, FeAc-1, CrNO3-1, and ZrNO3-1 materials exhibit a weak pH dependency, though not nearly as large as would be expected if surface complexation were the only scavenging mechanism involved. (“Ac” is an abbreviation for acetate.) The suite of 
experiments evaluating the impact of $\mathrm{pH}$ on iodate sorption produced a similar picture, with little variation in Kd over the $\mathrm{pH}$ range relevant to normal YMP-related groundwaters. However, the first few steps to increment the $\mathrm{pH}$ upward did typically result in a slight decrease in Kd (about half a log unit).

To summarize, it does not appear that generally the acid $\mathrm{pH}$ values reported earlier invalidate the generally favorable picture of iodide getter performance that seems to be developing. In all, a number of materials were identified that still retained iodine Kd values close to $10^{3}$ in mildly basic fluids such as might be encountered under repository conditions. Unfortunately, because the program was ended sooner than anticipated we were unable to establish why acidic conditions developed during batch Kd testing, or why there was such a large spread between the behaviors of the different materials.

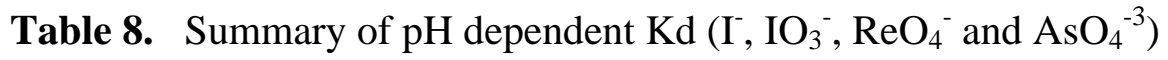

\begin{tabular}{|c|c|c|c|c|}
\hline & & Log Kd & Log Kd & Log Kd \\
\hline Getter & $\mathrm{pH}$ & lodide * & $\mathrm{ReO} 4$ & AsO4 \\
\hline FeAc-1 & 7.2 & 3.18 & 2.98 & GT 7 \\
\hline FeAc-1 & 7.4 & 3.18 & 1.70 & 6.96 \\
\hline FeAc-1 & 7.5 & 3.32 & 1.59 & 7.33 \\
\hline FeAc-1 & 7.8 & 3.32 & 1.68 & 7.70 \\
\hline FeAc-1 & 9.3 & 3.00 & 1.33 & 6.30 \\
\hline CrNO3-1 & 6.3 & 2.78 & 2.09 & 6.67 \\
\hline CrNO3-1 & 6.6 & 2.78 & 2.07 & 6.71 \\
\hline CrNO3-1 & 6.7 & 2.77 & 1.99 & 6.54 \\
\hline CrNO3-1 & 7.1 & 2.83 & 2.17 & 5.94 \\
\hline CrNO3-1 & 8.7 & 2.82 & 1.96 & 6.05 \\
\hline NiAc-1 & $\begin{array}{lll}6 & 1 \\
\end{array}$ & 3,42 & 195 & 4.71 \\
\hline NiAc-1 & 6.2 & 3.43 & 1.99 & 4.73 \\
\hline NiAc-1 & 6.5 & 3.46 & 2.20 & 4.71 \\
\hline NiAc-1 & 7.0 & 3.52 & 2.08 & 4.71 \\
\hline NiAc-1 & 8.9 & 3.55 & 1.85 & 4.76 \\
\hline BaNO3-1 & 5.4 & 3.64 & 1.96 & 5.03 \\
\hline BaNO3-1 & 5.8 & 3.61 & 2.05 & 4.86 \\
\hline BaNO3-1 & 6.3 & 3.58 & 1.99 & 5.00 \\
\hline BaNO3-1 & 6.7 & 3.58 & 1.99 & 4.46 \\
\hline BaNO3-1 & 6.9 & 3.57 & 1.81 & 4.23 \\
\hline ZrNO3-1 & 6.8 & 3.34 & 2.11 & 6.41 \\
\hline$\overline{\mathrm{ZrNO} 3-1}$ & 7.0 & 3.36 & 2.21 & 6.40 \\
\hline ZrNO3-1 & 7.4 & 3.41 & 1.92 & 6.00 \\
\hline ZrNO3-1 & 7.6 & 3.36 & 2.05 & 6.12 \\
\hline ZrNO3-1 & 9.0 & 3.19 & 2.12 & 5.46 \\
\hline
\end{tabular}

\begin{tabular}{|c|c|c|c|c|c|}
\hline & rest & $\log (\mathrm{Kd})$ & & rest & $\log (K d)$ \\
\hline Material & $\mathrm{pH}$ & for $1 \mathrm{O}_{3}^{-}$ & Material & $\mathrm{pH}$ & for $\mathrm{IO}_{3}^{-}$ \\
\hline $\mathrm{ZnAc1}$ & 5.565 & 3.00 & CuNO31 & 5.412 & 3.56 \\
\hline ZnAc1 & 5.535 & 2.82 & CuNO31 & 5.598 & 3.51 \\
\hline ZnAc1 & 6.099 & 2.86 & CuNO31 & 6.153 & 3.15 \\
\hline $\mathrm{ZnAc1}$ & 6.959 & 2.81 & CuNO31 & 6.6 & 3.23 \\
\hline ZnAc1 & 10.511 & 2.71 & CuNO31 & 10.501 & 2.65 \\
\hline ZnAc2 & 5.811 & 2.96 & CuNO32 & 6.931 & 2.77 \\
\hline ZnAc2 & 6.464 & 2.59 & CuNO32 & 7.033 & 2.79 \\
\hline ZnAc2 & 7.354 & 2.27 & CuNO32 & 8.451 & 2.86 \\
\hline ZnAc2 & 9.337 & 2.27 & CuNO32 & 10.247 & 2.43 \\
\hline ZnAc2 & 10.694 & 0.69 & CuNO32 & 10.749 & 1.63 \\
\hline ZnNO31 & 5.429 & 3.31 & CrNO32 & 6.874 & 4.15 \\
\hline ZnNO31 & 5.419 & 3.55 & CrNO32 & 7.146 & 4.00 \\
\hline ZnNO31 & 6.228 & 3.17 & CrNO32 & 7.867 & 4.10 \\
\hline ZnNO31 & 7.338 & 2.28 & CrNO32 & 8.29 & 3.82 \\
\hline ZnNO31 & 10.454 & 2.81 & CrNO32 & 9.938 & 3.31 \\
\hline ZnNO32 & 6.947 & 2.70 & NiAc2 & 6.609 & 1.71 \\
\hline ZnNO32 & 7.363 & 2.70 & $\mathrm{NiAc2}$ & 7.387 & 2.50 \\
\hline ZnNO32 & 8.298 & 2.68 & $\mathrm{NiAc2}$ & 8.634 & 2.55 \\
\hline ZnNO32 & 10.088 & 2.50 & NiAc2 & 9.908 & 2.69 \\
\hline ZnNO32 & 10.729 & 2.48 & NiAc2 & 10.747 & no sorption \\
\hline ZrNO32 & 6.938 & 3.13 & $\mathrm{BaNO} 32$ & 5.788 & 2.92 \\
\hline ZrNO32 & 7.337 & 3.15 & $\mathrm{BaNO} 32$ & 6.859 & 2.45 \\
\hline ZrNO32 & 8.476 & 3.08 & $\mathrm{BaNO} 32$ & 7.966 & 2.73 \\
\hline ZrNO32 & 9.508 & 2.70 & $\mathrm{BaNO} 32$ & 9.701 & 2.48 \\
\hline ZrNO32 & 10.522 & 2.76 & BaNO32 & 10.677 & 2.13 \\
\hline
\end{tabular}

$\mathrm{GT}=$ greater than, * Values presented in Fig. 4 


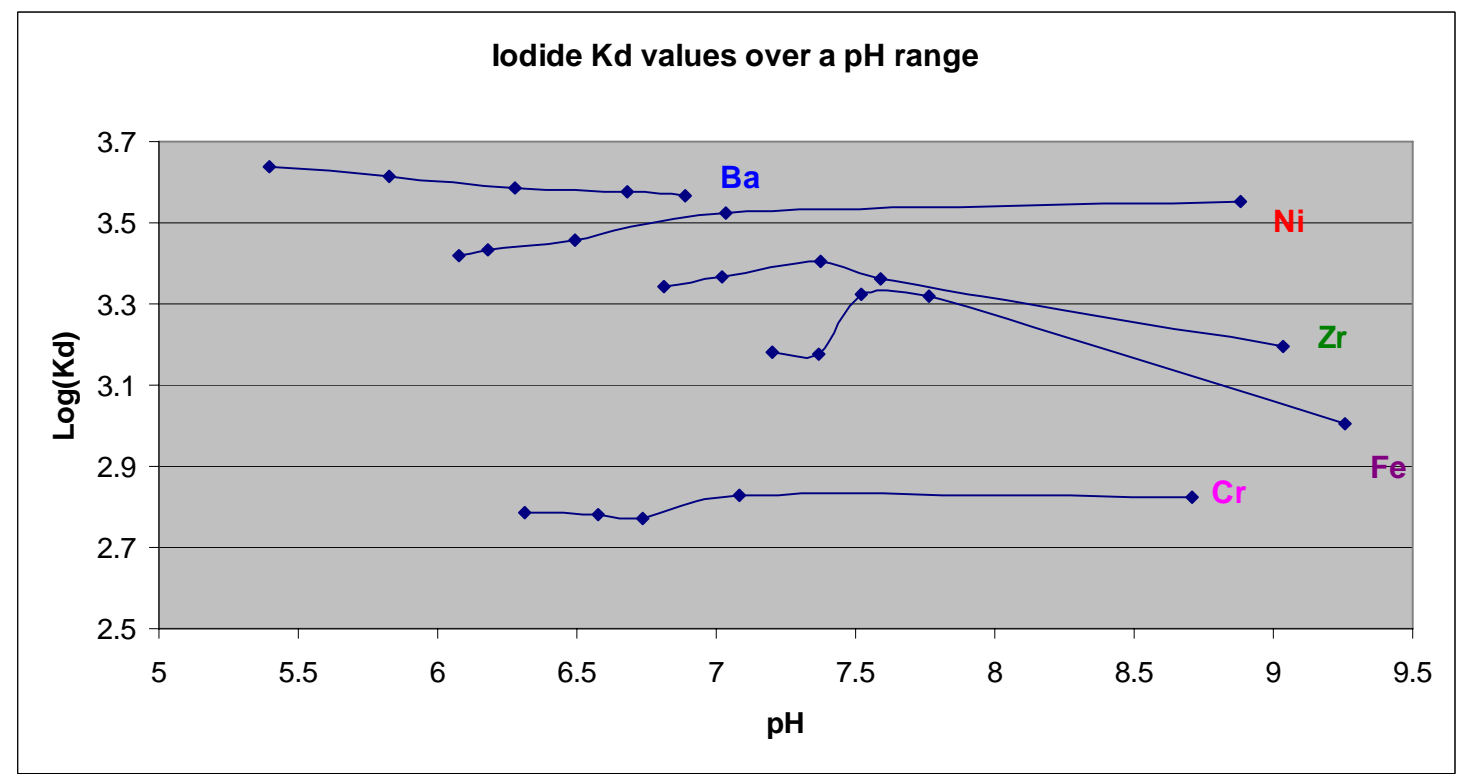

Fig. 4. Iodide Kd values determined with the post-grinding ratio of solid to liquid; $0.05 \mathrm{~g}$ solid to $50 \mathrm{ml}$ of fluid. (from 4-26-05 pH adjustments)

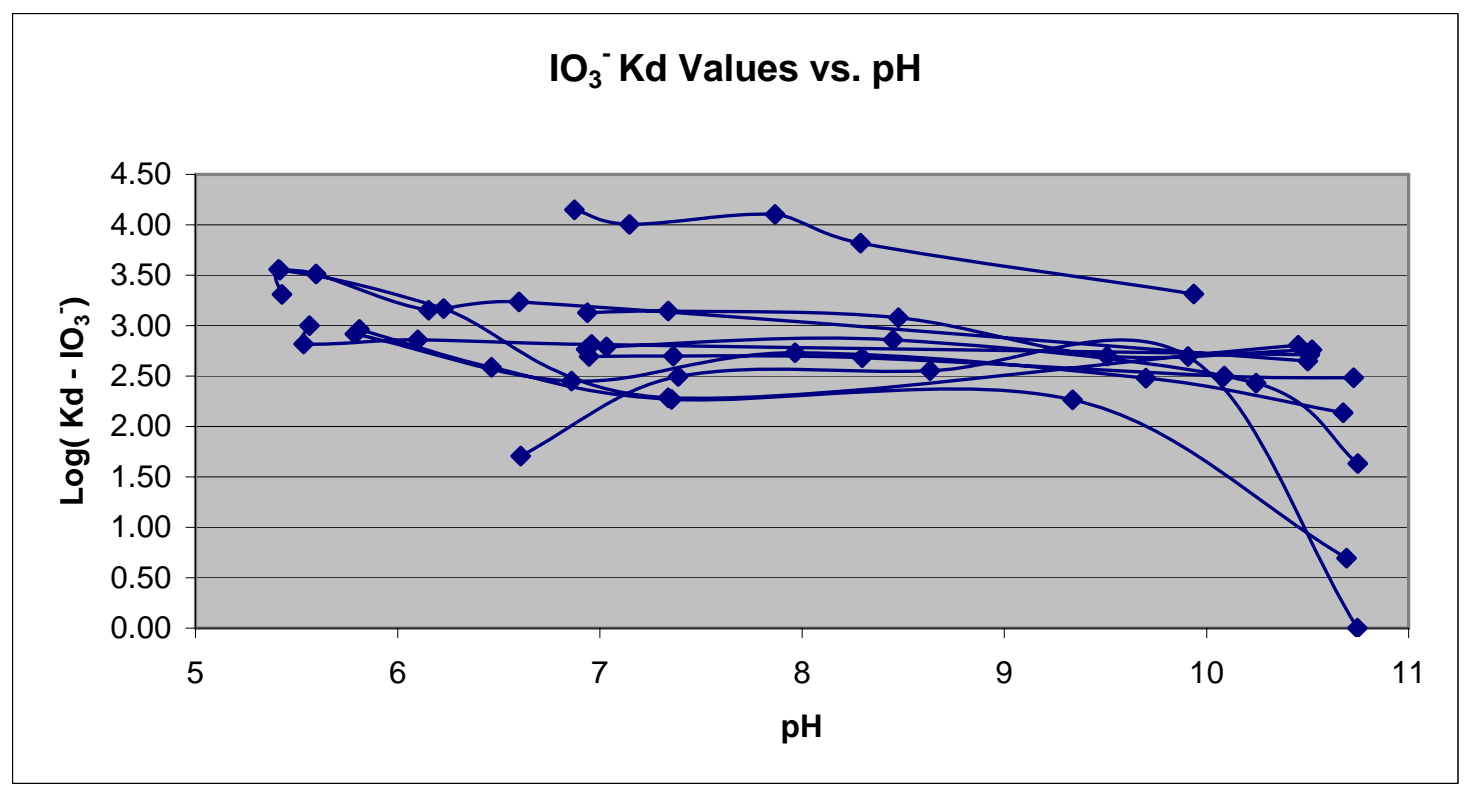

Fig. 5. Iodate Kd values determined with the post-grinding ratio of solid to liquid; $0.05 \mathrm{~g}$ solid to $50 \mathrm{ml}$ of fluid. (from 4-26-05 pH adjustments) 
Materials Characterization: All materials from this study were characterized using a batch "sorption" test process with "J-13 surrogate" water. Some materials synthesized early in the program (principally Round 1 materials from Table 5) were also characterized by X-ray diffraction (Appendix A, Table A-3 and Fig. A-1 to A-4.) and SEM (scanning electron microscope). In large measure, the X-ray diffraction studies showed these materials to be similar to the bismuth-containing samples produced years earlier for the TFA-funded study (Krumhansl et al., 2006; and Appendix B, Table B-3). Detailed examination, however, did allow for segregating some of the early synthesized (Round 1 ) materials into tentative groupings (designated Types I, II and III - Appendix A, Table A-3 and Fig. A-1 to A-4). Three classes of materials were discernable, none of which exactly match the relatively uniform materials produced by the standardized recipe used in the second round of mixed-metal synthesis studies (Tables 7 and 8). The distinctions between the performances of the different groupings are not large for iodide and arsenate. But, the Type II sorbers work substantially better for perrhenate, perchlorate and iodate. This suggests that a simple anion exchange process is involved for the monovalent oxy-anions, while a (stronger) surface complexation mechanism is involved in scavenging iodide and arsenate.

Table 9. Kd values for select Round 1 materials grouped by X-ray diffraction type (Appendix A).(These were very early tests that used an Albuquerque tap water matrix, $0.1 \mathrm{~g}$ sample to $10 \mathrm{ml}$ tap water with initially $2 \mathrm{ppm}$ of I, Re and As, or $20 \mathrm{ppm} \mathrm{ClO}_{4}^{-}$. Analytical techniques were generally still in the developmental stages at this time as well.)

\begin{tabular}{|c|c|c|c|c|c|}
\hline & "Type" & $\begin{array}{l}\mathrm{Kd}-n o t \text { Log } \\
\mathrm{ClO}_{4}^{-}\end{array}$ & $\begin{array}{l}\log \mathrm{Kd} \\
\mathrm{ReO}_{4}^{-}\end{array}$ & $\underset{I^{-}}{\log K d}$ & $\begin{array}{l}\log \mathrm{Kd} \\
\mathrm{AsO}_{4^{---}}\end{array}$ \\
\hline $\mathrm{p} 83 \alpha$ & II & 25.1 & 3.78 & 3.70 & 5.20 \\
\hline$p 83 \beta$ & $?$ & 0 & 0.02 & ns & 1.53 \\
\hline p83y & $?$ & 4.6 & -0.23 & 1.67 & 4.29 \\
\hline$p 9-1$ & 1 & 5.5 & 0.57 & 2.92 & 5.29 \\
\hline$p 9-2$ & I & 12.3 & 0.20 & 2.86 & 5.64 \\
\hline p9-3 & I & 11.8 & 0.39 & 2.71 & 5.58 \\
\hline$p 9-4$ & I & 11.8 & 0.53 & 3.12 & 5.62 \\
\hline$p 9-5$ & I & 7.9 & 0.75 & 2.84 & 4.85 \\
\hline p5-C orig. & II & 19.1 & 3.43 & 3.37 & 5.27 \\
\hline p5-C labled & II & 20.7 & 3.27 & 3.99 & 5.11 \\
\hline p5-D & I & 8.4 & 0.73 & 2.97 & 6.03 \\
\hline p5-H & I & 0 & 0.11 & ns & 5.17 \\
\hline p5-I & $1+?$ & 3.6 & 0.05 & ns & 3.83 \\
\hline p5-J & II & 4.6 & 0.84 & 1.80 & 5.30 \\
\hline p5-K & misc & 7.9 & 2.18 & 2.89 & 4.48 \\
\hline p5-L & II? & 20.2 & 3.85 & 3.10 & 4.72 \\
\hline BiNO3.5W & $?$ & $\mathrm{nt}$ & 1.15 & 3.92 & 5.24 \\
\hline p85 $\mu$ & III & $\mathrm{nt}$ & 2.44 & 3.48 & 5.19 \\
\hline p85v & II & nt & 3.30 & 3.67 & 5.11 \\
\hline p85ס & III & $\mathrm{nt}$ & 2.36 & 3.80 & 5.72 \\
\hline $\begin{array}{l}\text { Bi subsal. } \\
\text { nt - not test }\end{array}$ & 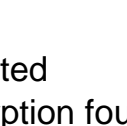 & $\mathrm{nt}$ & 1.40 & 2.43 & 4.40 \\
\hline
\end{tabular}


Some X-ray work was also done on the Round 2 materials, though the abrupt termination of the program precluded going very far with this study. Apparently the more standardized synthesis produced a material which can be distinguished by consistently having its strongest diffraction line being at about $7.5 \mathrm{deg}$. two-theta, while for the best crystallized early materials (Type I) the low angle peak is at about 8.5 deg. two-theta and it is not the strongest reflection.

SEM/EDS studies revealed that the solids precipitating from the mixed salt solutions only contained evidence of the second (non-bismuth) metal if the second metal formed an exceedingly insoluble hydroxide on its own (e.g., $\mathrm{Fe}^{+3}, \mathrm{Cr}^{+3} \mathrm{Zr}^{+4}, \mathrm{Mn}^{+4}$ ). In the other cases the effect of the second metal was apparently to influence the type of bismuth hydroxide layer structure that nucleated, though the second metal does not seem to have actually been incorporated into the structure. These distinctions seemed to be most pronounced among the materials produced by the less standardized processes used in Round 1. Most of the mixed-metal pairs produced during the Round 2 studies resembled P5-C (below, Fig. 6).

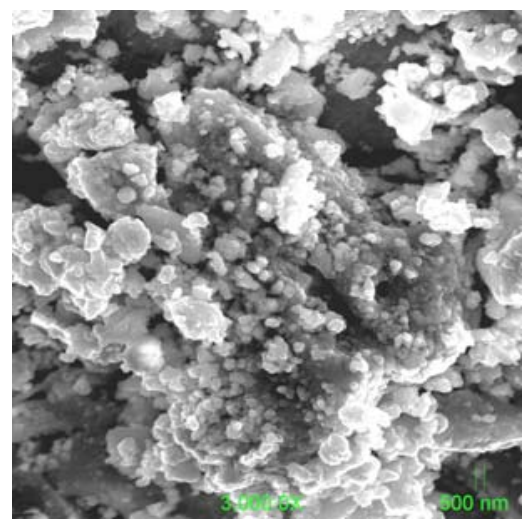

P5-C

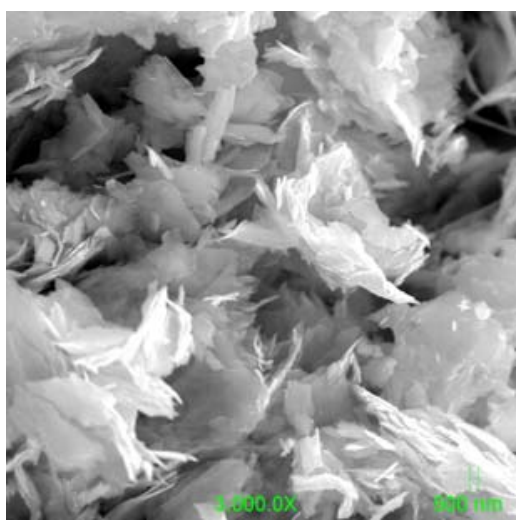

P9-2

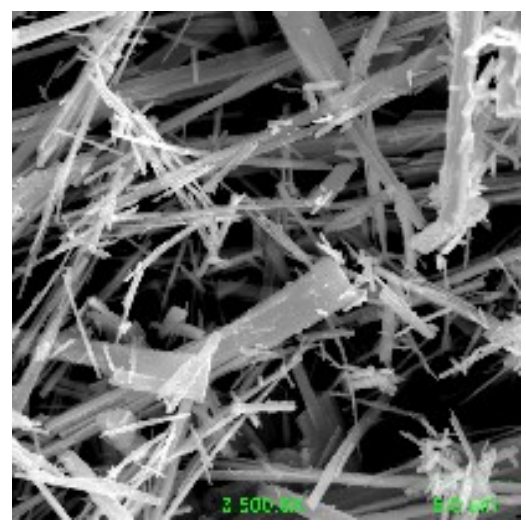

P5-E

Fig. 6. SEM photographs showing different textures of Bi-based getters; see Table 5 for performance and synthesis details. Occasionally a bladed structure results that is suggestive of layered materials (middle, P9-2). Often, however, the results are granular (left) or needle-like (right).

\section{d. Miscellaneous Materials}

Assorted materials that do not fit into any of the above categories are discussed below. Several of the samples consist of naturally occurring minerals, tungstates, phosphates or simple metal oxides or hydroxides. Some of the naturally occurring minerals studied contain copper in the hopes that the copper compounds generally could be shown to aid in sequestring iodide. The tungsten bronzes were studied because of their stability under a various oxidation states. The Cs$\mathrm{Cu}$-phosphates/arsenates were of interest because they are mesoporous materials. The simple metal oxides or hydroxides were studied to determine if the individual components of the complex materials studied above contributed to the sorption capacities. 
Table 10. Sorption Coefficients of Miscellaneous Compounds ${ }^{\mathrm{a}}$

\begin{tabular}{|c|c|c|c|}
\hline Targeted Composition & $\begin{array}{c}\log K_{d} \\
I^{-}\end{array}$ & $\begin{array}{c}\log \mathrm{K}_{\mathrm{d}} \\
\mathrm{IO}_{3}^{-}\end{array}$ & $\begin{array}{c}\log \mathrm{K}_{\mathrm{d}} \\
\mathrm{ReO}_{4}^{-}\end{array}$ \\
\hline Malachite & 1.2 & 2.5 & $<1$ \\
\hline Azurite & 1.3 & - & \\
\hline Chrysocolla & 1.1 & - & \\
\hline Montmorillonite - SWy-1 w/ Sn(II) & - & 1.0 & 2.3 \\
\hline Montmorillonite w/ Sn(II) & - & 1.5 & 3.1 \\
\hline Kaolinite w/ Sn(II) & - & $<1.4$ & 1.4 \\
\hline Saponite w/ Sn(II) & - & $<1.4$ & 1.3 \\
\hline $\mathrm{MgWO}_{4}+\mathrm{WO}_{3}$ & 1.28 & 1.09 & 0.84 \\
\hline $\mathrm{Fe}_{2} \mathrm{WO}_{6}+\mathrm{WO}_{3}$ & 1.25 & 1.09 & 0.95 \\
\hline $\mathrm{CoWO}_{4}$ & 0.98 & 1.13 & 1.11 \\
\hline $\mathrm{NiWO}_{4}$ & 0.59 & 1.10 & 1.08 \\
\hline $\mathrm{CuWO}_{4}$ & 1.46 & 0.87 & 0.63 \\
\hline $\mathrm{ZnWO}_{4}$ & 1.28 & 0.96 & 0.67 \\
\hline $\mathrm{CsCu}_{5} \mathrm{O}_{2}\left(\mathrm{AsO}_{4}\right)_{2} \mathrm{Cl}$ & 1.38 & - & - \\
\hline $\mathrm{K}_{2} \mathrm{Cs}_{3} \mathrm{Cu}_{3}\left(\mathrm{P}_{2} \mathrm{O}_{7}\right)_{2} \mathrm{Cl}_{3}$ & 1.68 & 0.86 & 1.14 \\
\hline $\mathrm{Cs}_{2} \mathrm{Cu}_{3}\left(\mathrm{P}_{2} \mathrm{O}_{7}\right)_{2} \times \mathrm{H}_{2} \mathrm{O}$ & 1.72 & 2.00 & 1.90 \\
\hline $\mathrm{CuZr}_{2}\left(\mathrm{PO}_{4}\right)_{3}$ & 2.42 & 1.34 & 1.33 \\
\hline $\mathrm{Cu}_{2} \mathrm{P}_{2} \mathrm{O}_{7}+\mathrm{Zr}_{2} \mathrm{P}_{2} \mathrm{O}_{7}$ & 1.32 & 1.29 & 1.19 \\
\hline $\mathrm{SnHPO}_{3}(\mathrm{JLK})$ & $<1.0$ & 0.5 & 1.4 \\
\hline $\mathrm{Al}(\mathrm{OH})_{3}$ Pure & $<1.0$ & - & - \\
\hline $\mathrm{Al}(\mathrm{OH})_{3} \mathrm{w} / \mathrm{SnCl}_{2}(0.5 \mathrm{~g})$ & 1.1 & - & - \\
\hline $\mathrm{MnO}_{3}$ & - & $<1.4$ & $<1.0$ \\
\hline $\mathrm{NiO}$ & 0.88 & 0.00 & 0.42 \\
\hline $\mathrm{Ni}(\mathrm{OH})_{2}$ & 0.84 & 2.73 & 0.62 \\
\hline $\mathrm{Cu}_{2} \mathrm{O}$ & 1.5 & $<1.4$ & $<1.0$ \\
\hline $\mathrm{CuO}$ & 1.0 & $<1.4$ & $<1.0$ \\
\hline $\mathrm{Sn}(\mathrm{OH}) \mathrm{xOx}$ acid titration (NA) & $<1.0$ & $<1.3$ & $<1.0$ \\
\hline $\mathrm{Sn}(\mathrm{OH})_{\mathrm{x}}, \mathrm{SnCl}_{2}$, Base titrat. (NA) & $<1.0$ & - & - \\
\hline $\mathrm{BaCO}_{3}(\mathrm{syn})$ (N.A.) & 1.0 & $<1.4$ & $<1.0$ \\
\hline Fe metal with $\mathrm{CuSO}_{4}$ & 2.6 & - & - \\
\hline $\mathrm{W}$ w/ Zn shot (NA) & - & $<1.4$ & 1.3 \\
\hline
\end{tabular}


Synthesis and Structural Characterization: The naturally occurring minerals were purchased at local mineral shops. They were then ground to a fine powder with an agate mortar and pestle.

Six polycrystalline tungstates were synthesized by solid state reaction. Stoichiometric amounts of $\mathrm{MgO}$ (Alfa Aesar, 95\%), $\mathrm{Fe}_{2} \mathrm{O}_{3}$ (Alfa Aesar, 99.9\%), $\mathrm{CoO}$ (Alfa Aesar, 95\%), NiO (Alfa Aesar, 99\%), $\mathrm{CuO}$ (Alfa Aesar 99.9\%) and $\mathrm{WO}_{3}$ (Alfa Aesar, 99.8\%) were ground with an agate mortar and pestle. The samples were calcined in air between $850-1000{ }^{\circ} \mathrm{C}$ for $24 \mathrm{~h}$. The materials were ground to a fine powder. Note: $\mathrm{WO}_{3}$ is present in both the magnesium sample because $\mathrm{Mg}(\mathrm{OH})_{2}$ was present in the $\mathrm{MgO}$ and the iron sample because the author failed to realize that $\mathrm{Fe}_{2} \mathrm{WO}_{6}$ would form.

Three Cs-Cu/phosphates/arsenates were supplied by Mutlu Kartin. The Cu-Zr-phosphates were were synthesized by solid state reaction. Stoichiometric amounts of $\left(\mathrm{NH}_{4}\right) \mathrm{H}_{2} \mathrm{PO}_{4}$ (Aldrich, 98\%), $\mathrm{CuO}$ (Alfa Aesar 99.9\%) and $\mathrm{ZrO}_{2}$ (Aldrich, 99\%) were ground with an agate mortar and pestle. The samples were calcined in air at $350{ }^{\circ} \mathrm{C}$ for $4 \mathrm{~h}$, at $850{ }^{\circ} \mathrm{C}$ for $16 \mathrm{~h}$, and at $1200{ }^{\circ} \mathrm{C}$ for $12 \mathrm{~h}$. The samples were removed after each heating step and reground to ensure mixing. The materials were ground to a fine powder.

The samples' structures were identified using powder X-ray diffraction (XRD). The XRD patterns were recorded at room temperature on a Siemens Kristalloflex D 500 diffractometer ( $\mathrm{Cu}$ $\mathrm{K} \alpha$ radiation, Kevex detector, $40 \mathrm{kV}, 30 \mathrm{~mA} ; 2 \theta) 5-60^{\circ}, 0.05^{\circ}$ step size and $3 \mathrm{~s}$ count time) and used for crystalline phase identification. The phases were identified by comparison with the data reported in the JCPDS (Joint Committee of Powder Diffraction Standards) database.

Results and Discussions: The physical properties and sorption coefficients of the miscellaneous materials are summarized in Table 10. Most of the iodide, iodate and perrhenate sorption capacities $\left(\mathrm{K}_{\mathrm{d}}\right)$ of these miscellaneous materials are unremarkable $\left(<10^{2}\right)$. Two samples have iodide sorption capacities that are greater than $10^{2} ; \mathrm{CuZr}_{2}\left(\mathrm{PO}_{4}\right)_{3}-10^{2.42}$ and Fe metal with $\mathrm{CuSO}_{4}-10^{2.6}$. Three samples have $\mathrm{IO}_{3}{ }^{-}$sorption capacities great than $10^{2}$; Malachite $-10^{2.5}$, $\mathrm{Cs}_{2} \mathrm{Cu}_{3}\left(\mathrm{P}_{2} \mathrm{O}_{7}\right)_{2}-10^{2}$ and $\mathrm{Ni}(\mathrm{OH})_{2}-10^{2.73}$. Finally, Montmorillonite exhibits a sorption capacity for $\mathrm{ReO}_{4}{ }^{-}$of $10^{2.3-3.1}$, though reduction of the $\mathrm{Re}(\mathrm{VII})$ may lie at the heart of the sequestration mechanism - in which case re-oxidation is a concern..

The range of adsorption for Montmorillonite demonstrates that sorption coefficients of minerals are strongly affected by impurities found in natural systems (and ferrous iron might be expected to play a similar role). It is not surprising that the tungstates did not exhibit high adsorption coefficients as these materials are structurally compact and are stable under a variety of oxidation states. Finally, occasional results found in the literature suggested that phosphates might play a significant role in radionuclide sorption (Anderson, 1998; Moore et al., 2001). Although no single phosphate exhibited multiple $\mathrm{K}_{\mathrm{d}} \mathrm{s}$ greater than 2 , as a class they showed promise for the sorption of $\mathrm{I}^{-}$and $\mathrm{IO}_{3}{ }^{-}$. Further investigation of several types of phosphates might yield promising materials for radioiodine sorption. 


\section{SUMMARY AND CONCLUSIONS}

The principal objective of this study was to evaluate a wide range of potential iodine getters under conditions relevant to their placement in the invert beneath waste canisters in the Yucca Mountain repository. Toward this end, numerous potential getters were identified from the literature, and from the first author's past research activities. Their relative performance was judged using a batch " $K_{d}$ " technique that employed a surrogate YMP-related groundwater ("J13"). Two classes of materials appeared to be particularly promising; members of the hydrotalcite-mineral family and similarly layered materials comprised (principally) of hydrous bismuth hydroxide. Both classes of materials produced several candidates with " $\mathrm{K}_{\mathrm{d}}$ " values greater than $10^{3}$, (the metric set by performance assessment studies, MacNeil et al., 1999. as defining a useful getter), and numerous materials that performed less well. Unfortunately, the getter program only lasted a year, making it impossible to develop an explanation for why similar materials performed so differently, or how one might optimize the best performing materials.

It is also extremely important to note that although these tests did use the "J-13" groundwater surrogate, these tests were far too limited in scope to be useful in defining how such getters would actually function inside a repository. The first step in addressing that issue would be to develop an extended test protocol that addresses difficult issues such as:

(1) How to show long term getter performance when only a few months (or at best years) are available to perform direct experimental observations on the getters;

(2) How to evaluate overall performance since the getter will have to function in a significant number of different environments;

(3) What actually defines acceptable getter performance?

Finally, although much remains to be learned about getter performance, a good start has been made at identifying potentially useful materials useful should a future need arise to further develop getters (or waste forms) to sequester the radionuclides targeted in this report. 


\section{REFERENCES}

Anderson, C.L., 1998, MS Thesis, Removal of Metals and Radionuclides Using Apatite and Other Natural Sorbants, University of New Mexico, Albuquerque N.M., May 1998.

Balsley, S.D., Brady, P.V., Krumhansl, J.L., and Anderson, H.L., 1998, Anion Scavengers for Low-Level Radioactive Waste Repository Backfills, Journal of Soil Contamination, V. 7, no. 2, p. $125-141$.

Balsley, S.D., Brady, P.V., Krumhansl, J.L., and Anderson, H.L., 1996, Iodide retention by metal sulfide surfaces : cinnabar (HgS) and and chalcocite (Cu2S), Environmental Science and Technology, v. 30, p. 3025-3027.

Bontchev, R.P., Bonhomme, F., Krumhansl, J.L., and Moore, R.C., Structural relaations and phase transformations in the system $\mathrm{BiOX}$ ( $\mathrm{X}=\mathrm{Cl}-, \mathrm{BO}-$, NO3-, CO3-2, and CH3COO-), 229 ACS National Meeting, San Diego, CA, March 13-17, 2005, INOR 866.

Brady, P.V., Anderson, B.E., and K.B. Helean, 2005, Waste Package Corrosion Studies Using Small Mockup Experiments, in OST\&I Annual Report 2005, DOE/RW-0851, p. 39-40

Busetto, C., Del Piero, G., and Manara, G., 1984, Catalysts for Low -Temperature Methanol Synthesis. Preparation of Cu-Zn-Al Mixed Oxides via Hydrotalcite-like Precursors, J. of Catalysis, v. 85, p. 260-266.

Davies, J.A. and Kent, D.B., 1990, Surface Complexation Modeling in Aqueous Geochemistry, in Mineral-Water Interface Geochemistry, Reviews in Mineralogy, V. 23, Hochella, M.V. and White, A.F. editors. p. 200-201.

Devyatkina, E.T., Kotsupalo, N.p., Tomilov, N.P., Berger, A.S., 1983, Lithium Hydroxycarbonatoalluminate, Russian Journal of Inorganic Chemistry, v. 28(6), p. 801804.

Fetter, G., Ramos, E., Olguin, M.T., Bosch, P., Lopez, T., and Bulbulian, S., 1997, Sorption of 131I- by hydrotalcites, J. of Radioanalytic and Nuclear Chem., v. 221 (1-2) p. 63-66).

Harbour, J.R., Edwards, T.B., Troy, H.L., Langton, C.A., Moore, R.C., Krumhansl, J.L., and Holt, K.C., 2004, Stabilizing Grout Compatibility Study, WSRC-TR-2004-00021, Rev. 0, printed Janudary, 2004.

Ikeda, Y., Sazarashi, M., Tsuji, M., Seki, R., Yoshikawa, H., Adsorption of I- ions on cinnabar for 129I waste management, Radiochimica Acta, v. 65, p.195-198.

Jow, H-N., Moore, R.C., and Mattigod, 2005, Radionuclide Getters Thrust, in OST\&I Annual Report 2005, DOE/RW-0851, p. 117-119 
Kang, M.J., Chun, K.S., Rhee, S.W., and Do, Y., 1999, Comparison of Sorption Behavior of $\mathrm{I}^{-}$ and $\mathrm{TcO}_{4}{ }^{-}$on $\mathrm{Mg} / \mathrm{Al}$ Layered Double Hydroxide, Radiochim. Acta, v. 85, p. 57-63.

Krumhansl, J.L., Pless, J.D., and Chwirka J.B., 2005, Iodine Getter Development, in Waste Package Corrosion Studies Using Small Mockup Experiments, in OST\&I Annual Report 2005, DOE/RW-0851, p. 133-134.

Krumhansl, J.L., Pless, J.D., and Cwirka, B., 2006, Screening Protocol for Iodine-Specific Getters in YMP-Related Invert Applications, SAND06-3857 (in press).

Krumhansl, J.L., Holt, K., and Bonhomme, F., 2002, “A Preliminary Assessment of Tc, I and Se Getter Development Activities for Hanford Tank Closure Applications”, Letter Report to US - DOE Tank Focus Area, Oct 14, 2002.

Lei, L., Millange, F., Walton, R.I., O’Hare, D., 2000, Efficient separation of pyridinedicarboxylates by anion exchange intercalation in [LiAl2(OH)6Cl.H2O], J. Mater. Chem., v. 10, p. 1881-1886.

MacNeil, K., Thiers, T.G., Zarrabi, K., McKenzie, D.G., and saunders, R.S., 1999, Diffusive Barrier and Getter Under Waste Packages VA Reference Design Feature Evaluations B00000000-01717-2200-00213 Revision 00C MOL 199902525.0399, YMP Program Design Document.

Mattigod, S.V., Fryxell, G.E., Serne, R.J., and Parker, K.E., 2003, Evaluation of novel getters for adsorption of radioiodine form groundwater and waste glass leachates, Radiochim Acta, v. 91(9) p. 539-545.

Moore, R.C., Sanchez, C., Schelling, J., Jones, J., Anderson, D.R., Salas, F., Lucero, D., and Holt, K., 2001, Bench-Scale Testing of In Situ Formation of Apatite in Hanford Soils for Sorption of Uranium and Technetium, SAND2001-3001.

Pless, J.D. Chwirka, J.B. and Krumhansl, J.L., 2006, Iodine Sequestration using Delaflossites and Layered Hydroxides, Environmental Chemistry Letters on line Journal, DOI 10.1007/s10311. 4 pp.

Tsuji, M., Ikeda, Y., Sazarashi, M., Yamaguchi, M., Matsunami, J., Tamaura, Y., 2000, A new family of anion exchangers: mixed hydroxide carbonates of $\mathrm{Bi}+3$ and divalent, metals showing high selectivity for SeO3=, Materials Research Bulletin v. 35, 2109-2122.

Velu, S., Sabde, D.P., Shah, N., and Sivasanker, S., 1998, New Hydrotalcite-Like Anionic Clays Containing Zr4+ in the Layers: Synthesis and Physiochemical Properties, Chem. Materials, v. 10, p. 3451-3458.

Velu, S., Suzuki, K., Osaki, T., Ohaslu, F., and Tomura, S., 1999, Synthesis of New Sn Incorporated Layered Double Hydroxides and their Evolution to Mixed Oxides, Materials Research Bulletin, v. 34 (10/11), p. 1701-1717. 


\section{APPENDIX A}

\section{Selected supplementary data for this study:}

Table A-1: Comparison of recipe for "J-13 surrogate" with literature "J-13" composition:

$\begin{array}{rc}\mathrm{mg} / \mathrm{kg} & \mathrm{mg} / \mathrm{kg} \\ \text { Recipe } & \text { Ref. J-13 } \\ 57.0 & 45.8 \\ 5.00 & 5 \\ 13 & 13 \\ 2.0 & 2\end{array}$

$\mathrm{SiO}_{2} \quad$ see note $\quad 28.5$

$\begin{array}{lll}\mathrm{Cl} & 7.1 & 7.1\end{array}$

$\mathrm{SO}_{4} \quad 22.6 \quad 18.4$

$\mathrm{HCO}_{3} \quad 152 \quad 152$

$\begin{array}{lll}\mathrm{NO}_{3} & 8.78 \quad 8.78\end{array}$

$\begin{array}{lll}\mathrm{F} & 2.18 & 2.18\end{array}$

$\mathrm{Na}^{*} \quad \mathbf{7 8 . 8} \quad 45.8$

* If silica is added in the soluble form of $\mathrm{Na}_{2} \mathrm{SiO}_{3} \cdot 9 \mathrm{H}_{2} \mathrm{O}$ the $\mathrm{Na}$ concentration increases to $78.8 \mathrm{mg} / \mathrm{kg}$, and the acid needed to bring the $\mathrm{pH}$ back into line will alter one of the anion concentrations.

Table A-2: Supplemental $\mathrm{TcO}_{4}{ }^{-} \mathrm{Kd}$ information:

Earliest Testing - Page 5

\begin{tabular}{|c|c|c|c|c|}
\hline Solid & $\begin{array}{l}\text { Initial } \\
\text { Activity }\end{array}$ & $\begin{array}{l}\text { After } \\
72 \text { hours }\end{array}$ & $\begin{array}{l}\% \\
\text { Sorbed }\end{array}$ & $\mathrm{Kd}$ \\
\hline "Bi(OH)3" ppted with no Li & 221000 & 166000 & 24.89 & 41.4 \\
\hline "Bi(OH)3" ppted with Li & 221000 & 58700 & 72.99 & 337.7 \\
\hline $\mathrm{Bi} 2 \mathrm{O} 3$ As received & $\begin{aligned} 221000 \\
\mathrm{pCi} / \mathrm{ml}\end{aligned}$ & 187000 & 15.38 & 22.7 \\
\hline
\end{tabular}

$221000 \mathrm{pCi} / \mathrm{ml}$ is $12.8 \mathrm{ppm}$ Tc or $1.29 \times 10^{-4}$ molar

Later $\mathrm{Kd} \mathrm{TcO}_{4}{ }^{-} \mathrm{Kd}$ values

\begin{tabular}{llcrr}
\multicolumn{1}{c}{ Sample } & $\begin{array}{c}\text { Beta } \\
\text { activity } \\
\text { (pCi/mL) }\end{array}$ & \% sorbed & \multicolumn{1}{c}{$\begin{array}{c}\text { \% } \\
\text { remaining }\end{array}$} & "Kd" \\
Pepto bismol & $7.80 \mathrm{E}+02$ & 52 & 48 & 163.4615 \\
P5D & $1.47 \mathrm{E}+03$ & 10 & 90 & 16.32653 \\
P5H & $1.74 \mathrm{E}+03$ & -7 & 107 & -9.48276 \\
P5I & $2.02 \mathrm{E}+03$ & -24 & 124 & -28.9604 \\
P5J & $2.04 \mathrm{E}+03$ & -25 & 125 & -30.1471 \\
P5K & $1.24 \mathrm{E}+03$ & 24 & 76 & 47.17742 \\
P5L & $8.78 \mathrm{E}+02$ & 46 & 54 & 128.4738 \\
P5F* & $1.70 \mathrm{E}+03$ & -4 & 104 & -6.17647 \\
Blank & $1.63 \mathrm{E}+03$ & 0 & 100 & 0
\end{tabular}

Each sample $0.2 \mathrm{~g}$, added to $30 \mathrm{~mL}$ Yucca Mtn. water. Spiked with Tc.

Sample P5F: only $0.05 \mathrm{~g}$ sample used in $30 \mathrm{~mL}$ water 
Table A-3: X-ray diffraction characteristics of early-synthesized materials (numbers refer to peak positions - 29, Cu Kó X-radiation.

\begin{tabular}{|c|c|c|c|c|c|c|c|c|c|c|}
\hline \multicolumn{11}{|c|}{ All peak positions are given as degrees two theta for copper K-alpha X-ray radiation } \\
\hline & & & \multicolumn{2}{|c|}{ "hydrotalcite" } & & & & & & \\
\hline & & "Type" & Peaks? & & & & & & & \\
\hline $86-1$ & $\mathrm{p} 83 \alpha$ & 1 & 7-9 trace & none & none & none & 24.5 trace & & none & 28.2 main \\
\hline $86-2$ & p83 $\beta$ & $?$ & & & & & & & & \\
\hline $86-3$, no 4 & p83y & $?$ & & & & & & & & \\
\hline $86-5$, no 4 & p9-1 & 1 & 8.50 & 17 & 21.8 & 23 & 23.7 & 25.6 & & 28.0 main \\
\hline $86-6$ & p9-2 & 1 & 9.00 & 17.4 & 22.2 & 23.3 & 23.9 & 25.9 & & 28.0 main \\
\hline $86-7$ & $p 9-3$ & 1 & 7.50 & 16.9 & 22 & 23.1 & 23.5 & 25.5 & & 28.0 main \\
\hline $86-8$ & p9-4 & 1 & 7.70 & 17 & 22.2 & 23.3 & 23.6 & 25.8 & & 28.0 main \\
\hline $86-9$ & $p 9-5$ & 1 & 7.60 & 17 & 21.1 & 23.3 & 23.5 & 25.8 & & 28.0 main \\
\hline $86-10$ & p5-C orig. & II & 8.60 & none & \begin{tabular}{|l|l|}
$19.7 \mathrm{tr}$ \\
\end{tabular} & none & 24.1 small & none & none & 28.3 main \\
\hline $86-11$ & p5-C labled & II & $6.0,8.4$ & none & none & none & 23.8 small & none & none & 28.0 main \\
\hline $86-12$ & p5-D & 1 & 8.2 sharp & $15.5,17,17.7$ & 22 & $23.0 \mathrm{tr}$ & 23.5 sharp & 25.6 small & none & 28.0 main \\
\hline $86-13$ & p5-H & 1 & 7.6 sharp & $14,15.1,16.5$ & \begin{tabular}{|l|}
$19.8,21.7$ \\
\end{tabular} & none & 24.3 small & 25.8 trace & 27.0sharp & 27.5 main \\
\hline 86-14 & p5-I & $1+?$ & 7.7 sharp & 7.6 & 11.0, 15.4, & 22.9 & none & none & & 27.6 sharp \\
\hline $86-15$ & p5-J & II & 6 small & none & $19.4 \mathrm{tr}$ & & 24.0 small & none & None & None \\
\hline $86-16$ & p5-K & misc & 9 trace & \multicolumn{3}{|c|}{ 10.5, 11.2, 11.7, 18.2, 19.5, 21.2, 22.0, } & none & $25,25.6$ & none & 28, 28.2(main), \\
\hline $86-17$ & p5-L & II? & 7.2 , nice & 10.2 & none & none & none & none & none & 29.5 main \\
\hline $86-18$ & BiNO3.5W & $?$ & & & & & & & & \\
\hline 86-19 & p85 $\mu$ & III & 7.0, nice & none & none & none & 24.0 small & none & 27.0 poor & 28.4 trace \\
\hline $86-20$ & p85v & II & 7.0 , nice & none & none & none & 24.0 small & none & $27.0 \mathrm{good}$ & 28.4 trace \\
\hline $86-21$ & p86ठ & III & none & none & none & none & 24.0 trace & none & \begin{tabular}{|l|l} 
none \\
\end{tabular} & 28.4 main \\
\hline & & & & & & & & & & \\
\hline $86-1$ & $\mathrm{p} 83 \alpha$ & 1 & none & 31.9 Sharp & & 42 trace & 45-48 hump & none & 54.5 sharp & 58 poor \\
\hline $86-2$ & $p 83 \beta$ & $?$ & & & & & & & & \\
\hline $86-3$, no 4 & p83y & $?$ & & & & & & & & \\
\hline $86-5$, no 4 & p9-1 & 1 & & 31.3 & 34.5 & 40.8 & 44.8 & 47.2 & 53.6 & 57.8 \\
\hline $86-6$ & $p 9-2$ & 1 & & 31.6 & 34.6 & 41.2 & 45.2 & 47.4 & 54 & 58.2 \\
\hline $86-7$ & p9-3 & 1 & & 31.3 & 34.5 & 40.7 & 44.9 & 47.1 & 53.6 & 57.8 \\
\hline $86-8$ & $p 9-4$ & 1 & & 31.5 & 34.4 & 41.1 & 45.1 & 47.3 & 53.8 & 57.9 \\
\hline $86-9$ & $p 9-5$ & 1 & & 31.4 & 34 & 41 & 44.9 & 47.2 & 53.7 & 57.9 \\
\hline $86-10$ & p5-C orig. & II & none & 31.9 & & 41.3 & 45.7 sharp & 47.6 broad & 54.6 sharp & 58.1 sharp \\
\hline $86-11$ & p5-C labled & II & none & 31.8 sharp & & 41.5 trace & 45.4 sharp & 47.5 broad & 54.2 sharp & 58.5broad \\
\hline $86-12$ & p5-D & 1 & none & \multicolumn{2}{|c|}{31.3 sharp 41.0 small } & & 44.5shapp & 47.0 sharp & 53.8 sharp & 58.0 sharp \\
\hline $86-13$ & p5-H & 1 & 28.0 sharp & \multicolumn{2}{|c|}{$29.5,30.6,33.435 .0$ etc. } & & $46.0,46.4$ & 47.6 trace & \multicolumn{2}{|c|}{$52.4,53.5,54.0,54.55 .5 .6,56.8,59,59$} \\
\hline $86-14$ & p5-I & $1+?$ & 28.5 small & 30.5 main & & \multicolumn{3}{|c|}{$32.7,38.4,40.3,45.0,45.5,46.5,50.0$} & 52.8 large & \\
\hline $86-15$ & p5-J & III & 25-31 hump & 32.5 main & & 38.6 broad & 46.7sharp & 47.2 small & 53-58 hump & \\
\hline $86-16$ & p5-K & misc & \multicolumn{6}{|c|}{$28.7,29.5,30.231 .5$, etc looks to be pretty well crystalline } & & \\
\hline $86-17$ & p5-L & II? & 28-33 hump & 32.5 sharp & & 42 trace & 46.5 broad & 48 sharp & 52-58 hump & \\
\hline 86-18 & BiNO3.5W & $?$ & & & & & & & & \\
\hline $86-19$ & $\mathrm{p} 85 \mu$ & III & 28-33 hump & 33.0 sharp & & 43.5 trace & 47.0 sharp & 48 trace & $52-58$ hump & \\
\hline $86-20$ & $\mathrm{p} 85 \mathrm{v}$ & II & 28-33 hump & 33.0 sharp & & 43.5 trace & 47.0 sharp & none & 52-58 hump & \\
\hline 86-21 & p86ठ & III & 28-33 hump & 33.0 small & & none & 47.0 sharp & none & 52-58 hump & \\
\hline $86-1$ & \multicolumn{3}{|c|}{ similar to $\mathrm{p} 5 \mathrm{~L}$ but shfited } & & & & & & & \\
\hline \multicolumn{11}{|l|}{$86-2$} \\
\hline \multicolumn{11}{|l|}{$86-3$, no 4} \\
\hline \multicolumn{11}{|l|}{$86-5$, no 4} \\
\hline $86-6$ & & & & & & & & & & \\
\hline $86-7$ & & & & & & & & & & \\
\hline $86-8$ & & & & & & & & & & \\
\hline $86-9$ & & intermediat & te small pea & ats at 49 and & 51 & & & & & \\
\hline $86-10$ & wide little a & 34.4 & & & & & & & & \\
\hline $86-11$ & wide little a & $31.2,41.5$ & & & & & & & & \\
\hline $86-12$ & yellow -Bi2 & O3?? - ell xl & line, decent & small peaks & s at $12.0,22$ & $2.0,23.2,25$ & $5.5,32.4,34$ & 4.5 (pretty la & arge), and 35 & 5.2 \\
\hline $86-13$ & & other peaks & s at $14.0,15$ & $5.0,16.6,19$ & $9.7,22.0,22$ & $2.6,24.3,26$ & & & & \\
\hline $86-14$ & & & & & & & & & & \\
\hline $86-15$ & & & & & & & & & & \\
\hline $86-16$ & & & & & & & & & & \\
\hline $86-17$ & sharp salt $p$ & peaks at 10. & .5 and 31.5, & similar to $\mathrm{p}$ & $83 \alpha$ but shif & ffted & & & & \\
\hline $86-18$ & & & & & & & & & & \\
\hline $86-19$ & & & & & & & & & & \\
\hline $86-20$ & & & & & & & & & & \\
\hline $86-21$ & & & & & & & & & & \\
\hline
\end{tabular}


Typical X-ray diffraction patterns for various kinds of Bi based getter materials

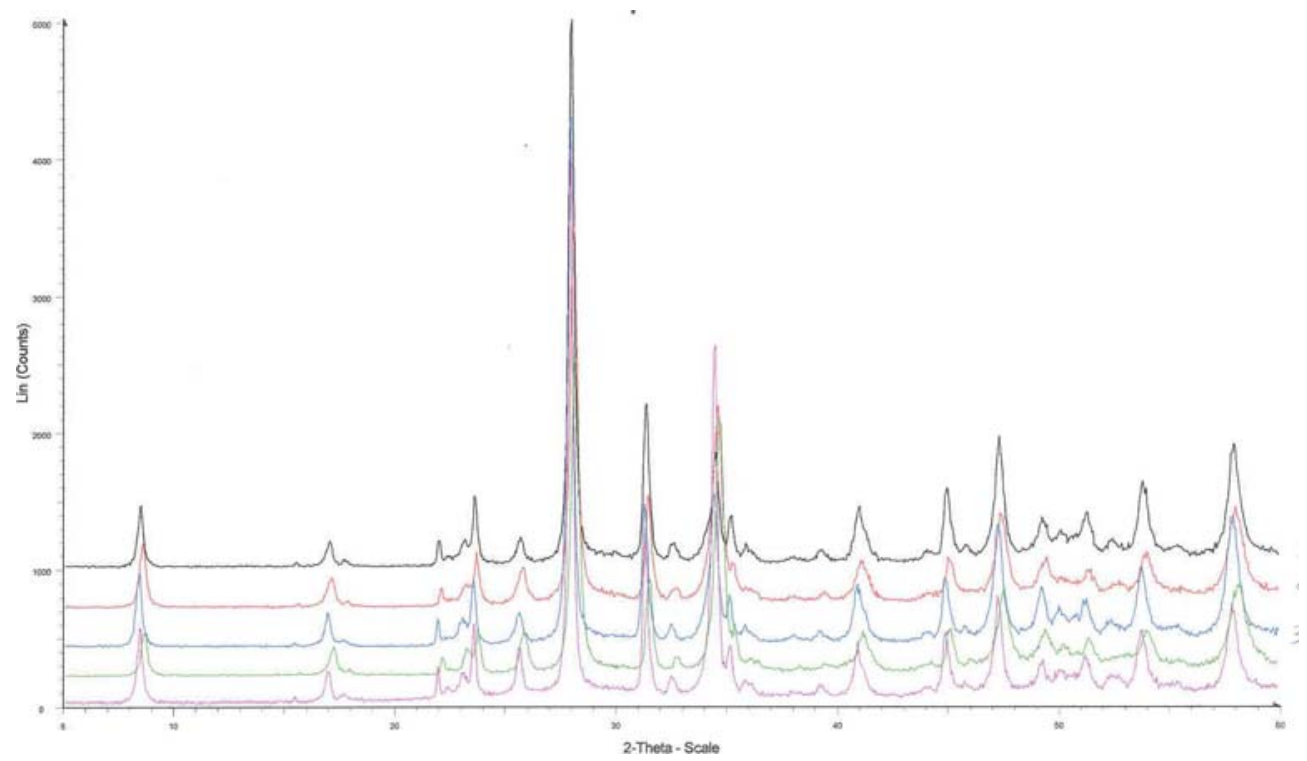

Fig. A-1: Typical “Type I" diffraction patterns (from the bottom up: p9-1 (purple), p9-2 (green), p9-3 (blue), p9-4 (brown), p9-5 (black).

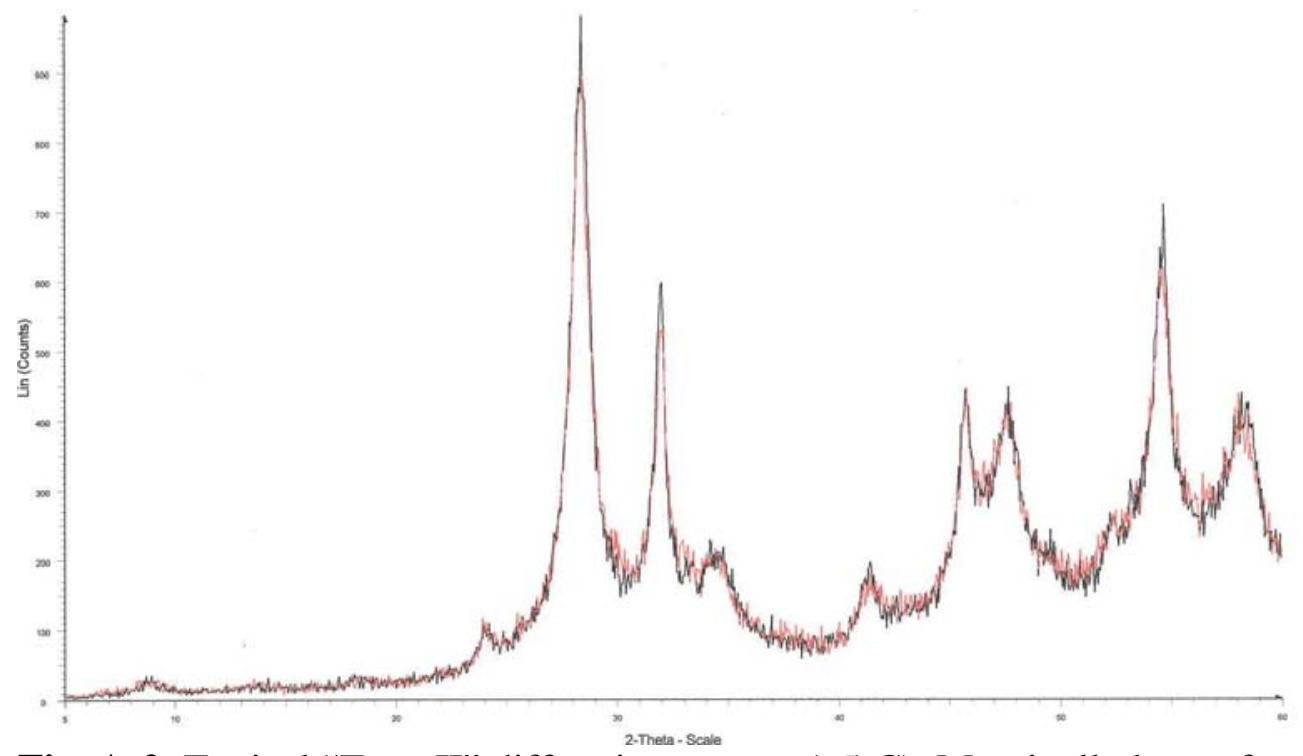

Fig. A-2: Typical “Type II” diffraction pattern (p5-C). Marginally better for $\mathrm{ClO}_{4}{ }_{4}$, $\mathrm{I}^{`}$ and $\mathrm{ReO}_{4}{ }^{-}$. 


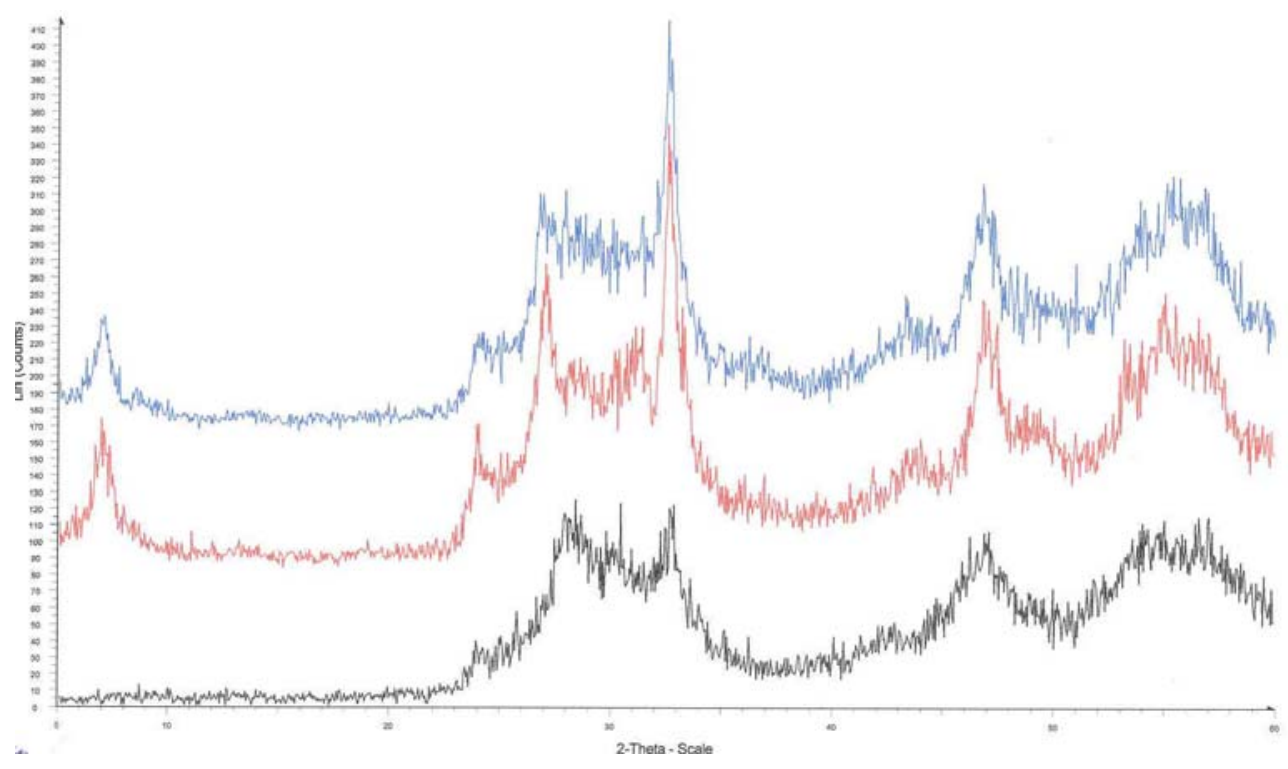

Fig A-3: Top: “Type III” diffraction patterns p85-m (blue, top) and p85- $\delta$ (red, middle), with a poorly expressed “Type II” pattern, p85-v (black, bottom) below for comparison.

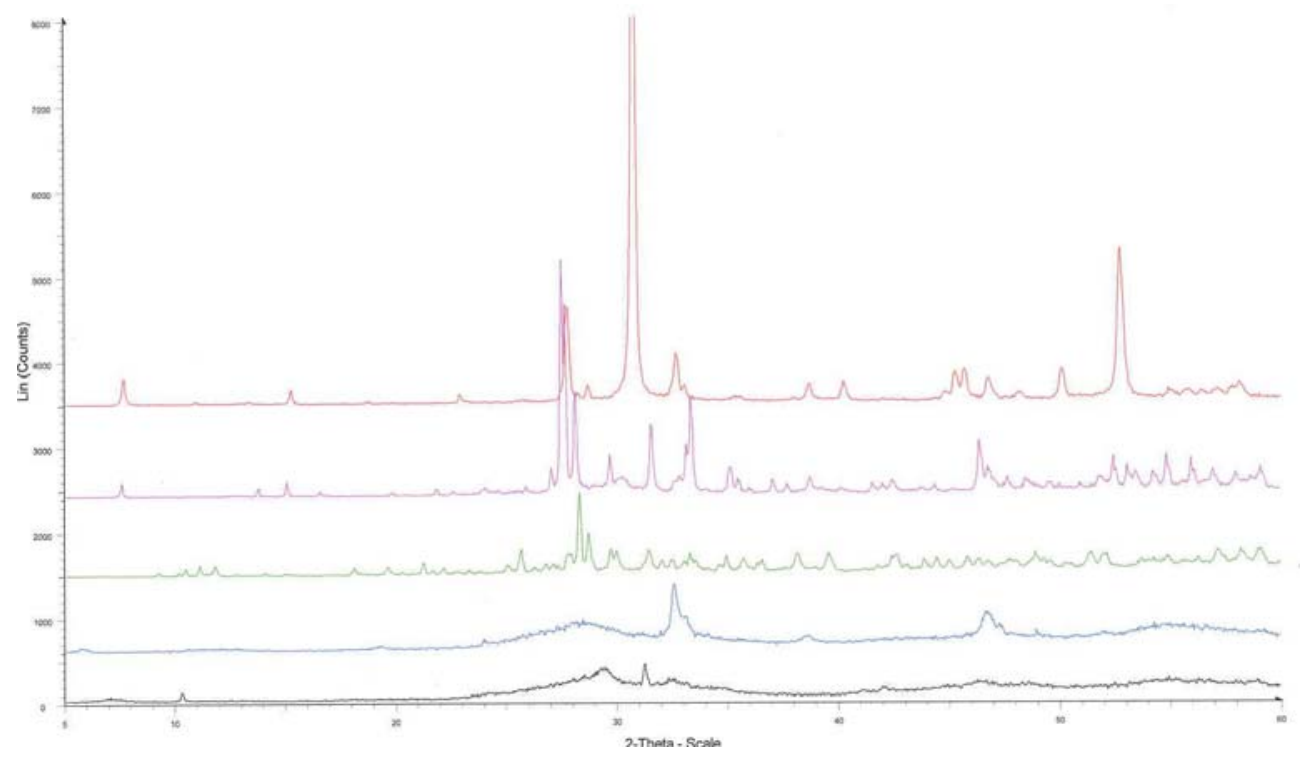

Fig A-4: Additional Bi getter diffraction patterns: from the bottom up; p5-L (black), p5-J (blue), p5-K (green), p5-H (purple) and p5-I (brown) 
Table A-4: Synthesis notes and supplemental Kd values for materials synthesized in the first round of testing for this project:

\begin{tabular}{|c|c|c|}
\hline & & Material synthesis and performance notes \\
\hline & & Step 1 \\
\hline $86-1$ & p83a & 8.758 g BiNO3.5W, 5.145 g HNO3 (30\%), 17.416 g H2O, 10.345 g LiNO3 \\
\hline $86-2$ & p83 $\beta$ & 8.784 g BiNO3.5W, 5.129 g HNO3 (30\%), 17.264 g H2O, 10.346 g LiNO3, dissolves \\
\hline $86-3$, no 4 & p83y & 8,902 g BiNO3.5W, $5.370 \mathrm{~g} \mathrm{HNO3(30 \% ),} 17.216 \mathrm{~g} \mathrm{DI}, 10.692 \mathrm{~g}$ LiNO3 \\
\hline $86-5$, no 4 & p9-1 & 8.368g Bi(NO3)3.5W, 5.217 g HNO3(30\%) 25.221 g H2O 1.083 g LiNO3 \\
\hline $86-6$ & p9-2 & $8.279 \mathrm{~g} \mathrm{Bi}(\mathrm{NO} 3) 3.5 \mathrm{~W}, 5.205 \mathrm{~g} \mathrm{HNO}(30 \%) 25.318 \mathrm{~g} \mathrm{H} 2 \mathrm{O} 15.646 \mathrm{~g} \mathrm{KNO}$ \\
\hline 86-7 & p9-3 & $8.205 \mathrm{~g} \mathrm{Bi}(\mathrm{NO} 3) 3.5 \mathrm{~W}, 5.255 \mathrm{~g} \mathrm{HNO}(30 \%) 26.370 \mathrm{~g} \mathrm{H} 2 \mathrm{O} 1.565 \mathrm{~g} \mathrm{KNO}$ \\
\hline $86-8$ & p9-4 & $8.273 \mathrm{~g} \mathrm{Bi}(\mathrm{NO} 3) 3.5 \mathrm{~W}, 5.230 \mathrm{~g} \mathrm{HNO}(30 \%) 25.631 \mathrm{~g} \mathrm{H} 2 \mathrm{O} 13.363 \mathrm{~g} \mathrm{NaNO}$ \\
\hline $86-9$ & p9-5 & $8.266 \mathrm{~g} \mathrm{Bi}(\mathrm{NO} 3) 3.5 \mathrm{~W}, 5.386 \mathrm{~g} \mathrm{HNO}(30 \%) 25.723 \mathrm{~g} \mathrm{H} 2 \mathrm{O} 1.383 \mathrm{~g}$ NaNO3 \\
\hline $86-10$ & p5-C orig. & $8.25 \mathrm{~g} \mathrm{Bi}(\mathrm{NO}) 3.5 \mathrm{~W}, 10.845 \mathrm{~g}$ LiNO35.350 g HNO3(30\%) $17.343 \mathrm{~g} \mathrm{H} 2 \mathrm{O} ?$ \\
\hline $86-11$ & p5-C labled & $8.25 \mathrm{~g} \mathrm{Bi}(\mathrm{NO} 3) 3.5 \mathrm{~W}, 10.845 \mathrm{~g}$ LiNO35.350 g HNO3(30\%) $17.343 \mathrm{~g} \mathrm{H} 2 \mathrm{O}$ \\
\hline $86-12$ & p5-d & 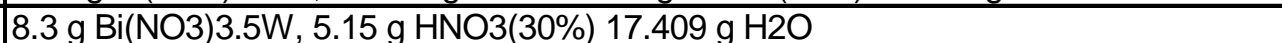 \\
\hline $86-13$ & p5-h & $8.249 \mathrm{~g} \mathrm{Bi}(\mathrm{NO} 3) 3.5 \mathrm{~W}, 4.698 \mathrm{~g} \mathrm{HNO}(30 \%) 54.507 \mathrm{~g} \mathrm{H} 2 \mathrm{O} 15.525 \mathrm{~g} \mathrm{KNO}$ \\
\hline 86-14 & p5-I & $8.179 \mathrm{~g} \mathrm{Bi}(\mathrm{NO} 3) 3.5 \mathrm{~W}, 5.15 \mathrm{~g} \mathrm{HNO}(30 \%) 29.408 \mathrm{~g} \mathrm{H} 2 \mathrm{O}, 13.350 \mathrm{~g} \mathrm{NaNO}$ \\
\hline $86-15$ & p5-j & 8.129g Bi(NO3)3.5W, $12.566 \mathrm{~g} \mathrm{HNO3(30 \% )} 18.863 \mathrm{~g} \mathrm{H} 2 \mathrm{O}, 15.141 \mathrm{~g} \mathrm{Ni(NO3)2.6 \textrm {W }}$ \\
\hline $86-16$ & p5-k & 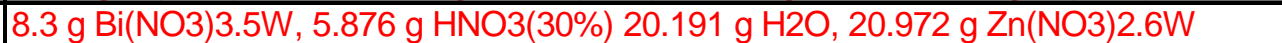 \\
\hline 86-17 & p5-I & $8.116 \mathrm{~g} \mathrm{Bi}(\mathrm{NO} 3) 3.5 \mathrm{~W}, 2.083 \mathrm{~g} \mathrm{HNO}(30 \%) 20.069 \mathrm{~g} \mathrm{H} 2 \mathrm{O}, 1.542 \mathrm{~g} \mathrm{Zn(NO3)2.6 \textrm {W }}$ \\
\hline 86-18 & BiNO3.5W & $0.0168 \mathrm{~g}$ of $\mathrm{Bi}(\mathrm{NO} 3) 3.5 \mathrm{~W}$ [equivalent to $0.0090 \mathrm{~g} \mathrm{Bi}(\mathrm{OH}) 3$ ] added to the fluid with no ammendments \\
\hline $86-19$ & $\mathrm{p} 85 \mu$ & $8.268 \mathrm{~g}$ BiNO3.5W, $5 \mathrm{~g} \mathrm{HOAc,} 5 \mathrm{~g} \mathrm{H} 2 \mathrm{O}$ \\
\hline $86-20$ & p85v & $8.340 \mathrm{~g}$ BiNO3.5W, $5.051 \mathrm{HOAc}, 5.289 \mathrm{~g} \mathrm{H} 2 \mathrm{O}, 10.407 \mathrm{~g}$ LiNO3, $9.230 \mathrm{~g} \mathrm{NH} 4$ Acetate \\
\hline $86-21$ & p86ס & $8.710 \mathrm{~g}$ BiNO3.5W, $8.8 \mathrm{~g} \mathrm{HOAc}, 19.32 \mathrm{~g} \mathrm{H} 2 \mathrm{O}$ \\
\hline $86-22$ & Bi-Subsal. & $0.203 \mathrm{~g}$ Bi-subsalicylate added to the fluid without other ammendments \\
\hline & & \\
\hline & & Step 2, sometimes \\
\hline 86-1 & p83a & None \\
\hline $86-2$ & $\mathrm{p} 83 \beta$ & Next, add $6.056 \mathrm{~g}$ Na benzonate sat, $36.123 \mathrm{~g}$ di, $39.46 \mathrm{~g}$ HNO3(30\%) \\
\hline $86-3$, no 4 & p83y & $6.13 \mathrm{~g} \mathrm{Na}$-benzoate in $\mathrm{NH} 4 \mathrm{OH}$ - maybe about 6.5 grams?? \\
\hline $86-5$, no 4 & p9-1 & None \\
\hline $86-6$ & p9-2 & None \\
\hline 86-7 & p9-3 & None \\
\hline $86-8$ & p9-4 & None \\
\hline $86-9$ & p9-5 & None \\
\hline $86-10$ & p5-C orig. & None \\
\hline $86-11$ & p5-C labled & None \\
\hline $86-12$ & p5-d & None \\
\hline $86-13$ & p5-h & None \\
\hline 86-14 & p5-I & None \\
\hline $86-15$ & p5-j & None \\
\hline $86-16$ & p5-k & None \\
\hline $86-17$ & p5-I & None \\
\hline $86-18$ & BiNO3.5W & None \\
\hline 86-19 & $\mathrm{p} 85 \mu$ & 5.563g Li2CO3, $17.05 \mathrm{~g} \mathrm{HOAc}, 7.8 \mathrm{~g} \mathrm{H} 2 \mathrm{O}$. \\
\hline $86-20$ & p85v & None \\
\hline $86-21$ & p86ठ & $5.529 \mathrm{~g} \mathrm{Li} 2 \mathrm{CO} 3,9.25 \mathrm{~g} \mathrm{HOOAc}, 25 \mathrm{ml} \mathrm{H} 2 \mathrm{O}$ \\
\hline $86-22$ & Bi-Subsal. & None \\
\hline
\end{tabular}




\title{
APPENDIX B \\ Results from earlier TFA-sponsored getter studies
}

The TFA-sponsored study was carried out in the 2001-2002 time-frame and laid the groundwork for many of the approaches exploited in the current study. However, since copies of contractor letter reports can be difficult to obtain (particularly when the funding entity was later disbanded) the effort was made to extract the main findings from that report and summarize them here. The basic venue of the work was to support the decommissioning of HLW tanks at Hanford by providing a sorbant barrier to prevent radionuclides remaining in decommissioned tanks from migrating into local groundwaters. In this setting both concrete and diluted (mildly basic) HLW fluid (DSSF-7) could be presumed to exist together with the getter. These were the chemical parameters which defined the performance envelope for the materials tested for the TFA application. Notably, many materials synthesized for this study were archived (those given "HT-\#" designations) and served as starting materials referenced in the current study. The additional performance data (relative to mildly elevated $\mathrm{pH}$ values and the presence of ordinary Portland cement, “OPC"), could also be applicable in the future if structural concrete ever becomes a more prominent feature in the YMP repository design.

\section{"A Preliminary Assessment of Tc, I and Se Getter Development Activities for Hanford Tank Closure Applications"}

\section{Letter Report to US - DOE Tank Focus Area, Oct 14, 2002:}

\section{J.L. KrumhansI \\ Kathleen Holt (6849) and \\ Francois Bonhomme (6118)}

\begin{abstract}
:
Controlling the migration of residual radionuclides is an important step in solving the high level waste (HLW) tank closure problem at Hanford and Savannah River. One strategy is to place materials in the tanks prior to or during closure operations that will radically lower the solubility of radioisotopes left in the tanks. Performance assessments have often identified ${ }^{99} \mathrm{Tc}$, and to a lesser degree ${ }^{129} \mathrm{I}$ and ${ }^{79} \mathrm{Se}$, as being likely to migrate from decommissioned tanks. An experimental program was undertaken to assess if various mixed metal hydroxides (similar to hydrotalcites) could provide effective barriers. Tc was tested in full strength tank simulant solutions as well as their diluted equivalents. In full strength solutions the highest Tc Kd obtained with a seven day exposure time is about 18 $\mathrm{L} / \mathrm{kg}$, while in the diluted tank liquors (1\% DSSF-7) a few materials yielded much higher Tc Kd values in the range of several thousand. While potentially useful in some applications, none of these Tc Kd values are competitive with the results obtained in a parallel study evaluating the use of stannous chloride treated apatite (calcium hydroxyphosphate) getters. Getters for I and Se were only tested in 1\% DSSF-7 solutions. The highest Kd values obtained with 26-day exposure times were $10^{+4.9} \mathrm{~L} / \mathrm{kg}$ for I and $10^{+3.9} \mathrm{~L} / \mathrm{kg}$ for Se. Portland cement was found to not adversely effect this performance and may alone provide a barrier to the migration of I and Se. Compositional trends were identified that could provide improved materials if performance assessment calculations demonstrated a need for further materials development.
\end{abstract}


Table B-1: Formulation for DSSF-7 $\left(7 \mathrm{M} \mathrm{Na}^{+}\right)$Hanford Tank Simulant

\begin{tabular}{|l|c|c|}
\hline \multicolumn{1}{|c|}{ Component } & Molarity & g/L \\
\hline & & \\
\hline $\mathrm{NaNO}_{3}$ & 1.162 & 98.77 \\
\hline $\mathrm{KNO}_{3}$ & 0.196 & 19.82 \\
\hline $\mathrm{KOH}$ & 0.749 & 42.03 \\
\hline $\mathrm{Na}_{2} \mathrm{SO}_{4}$ & .008 & 1.09 \\
\hline $\mathrm{Na}_{2} \mathrm{HPO}_{4} \cdot 7 \mathrm{H}_{2} \mathrm{O}$ & .014 & 3.75 \\
\hline $\mathrm{NaOH}$ & 3.885 & 155.40 \\
\hline $\mathrm{Al}\left(\mathrm{NO}_{3}\right)_{3} \cdot 9 \mathrm{H}_{2} \mathrm{O}$ & 0.721 & 270.48 \\
\hline $\mathrm{Na}_{2} \mathrm{CO}_{3}$ & 0.147 & 15.58 \\
\hline $\mathrm{NaCl}_{\mathrm{NaNO}}$ & 0.102 & 5.98 \\
\hline $\mathrm{Nan}_{2}$ & 1.512 & 104.33 \\
\hline
\end{tabular}

Table B-2: Summary of mixed metal hydroxides synthesized for this study

\begin{tabular}{|c|c|c|c|}
\hline HT-\# & $\mathrm{M}^{+2}$, and substitutions & $\mathrm{M}^{+3}$, and substitutions & $\begin{array}{l}\text { Anions that were } \\
\text { present }\end{array}$ \\
\hline 1 & $\mathrm{Zn}>\boldsymbol{S n}^{+2}$ & $\mathrm{Al}$ & $\mathrm{SO}_{4}{ }^{=}>\mathrm{CO}_{3}{ }^{=}, \mathrm{OH}^{-}, \mathrm{Cl}^{-}$ \\
\hline 2 & $\mathrm{Zn}>\boldsymbol{S n}^{+2}$ & $\mathrm{Al}$ & $\mathrm{SO}_{4}{ }^{=}>\mathrm{OH}^{-}, \mathrm{Cl}^{-}$ \\
\hline 3 & $\mathrm{Zn}$ & $\mathrm{Bi}$ & $\mathrm{SO}_{4}{ }^{=}>\mathrm{OH}^{-}, \mathrm{Cl}^{-}, \mathrm{NO}_{3}^{-}$ \\
\hline 4 & $\mathrm{Mg}$ & $\mathrm{Bi}$ & $\mathrm{CO}_{3}{ }^{=}>\mathrm{OH}^{-}$ \\
\hline 5 & $\mathrm{Zn}$ & $\mathrm{Al}$ & $\mathrm{SO}_{4}{ }^{=}>\mathrm{OH}^{-}, \mathrm{NO}_{3}{ }^{-}$ \\
\hline 6 & $\mathrm{Mg}$ & $\mathrm{Bi}$ & $\mathrm{SO}_{4}{ }^{=}>\mathrm{OH}^{-}, \mathrm{NO}_{3}{ }^{-}$ \\
\hline 7 & $\mathrm{Zn}$ & $\mathrm{Bi}$ & $A c>\mathrm{OH}^{-}, \mathrm{NO}_{3}^{-}$ \\
\hline 8 & $\mathrm{Zn}$ & $\mathrm{Al}$ & $A c>\mathrm{OH}^{-}, \mathrm{NO}_{3}^{-}$ \\
\hline 9 & $\mathrm{Mg}$ & $\mathrm{Al}$ & $A \boldsymbol{c}>\mathrm{OH}^{-}, \mathrm{NO}_{3}^{-}$ \\
\hline 10 & $\mathrm{Zn}$ & $\mathrm{Bi}$ & $A \boldsymbol{c}>\mathrm{OH}^{-}, \mathrm{NO}_{3}^{-}$ \\
\hline 11 & $\mathrm{Zn}>\mathrm{Cu}^{++}$ & $\mathrm{Bi}$ & $A \boldsymbol{c}>\mathrm{OH}^{-}, \mathrm{NO}_{3}^{-}, \mathrm{SO}_{4}=$ \\
\hline 12 & $\mathrm{Mg}>\boldsymbol{C u}^{++}$ & $\mathrm{Bi}$ & $A \boldsymbol{c}>\mathrm{OH}^{-}, \mathrm{NO}_{3}^{-}, \mathrm{SO}_{4}=$ \\
\hline 13 & Zn $>\boldsymbol{C u}^{++}$overheated & $\mathrm{Bi}$ & $A \boldsymbol{c}>\mathrm{OH}^{-}, \mathrm{NO}_{3}^{-}, \mathrm{SO}_{4}=$ \\
\hline 14 & $\mathrm{Mg}$ & $\mathrm{Al}$ & $A \boldsymbol{c}>\mathrm{OH}^{-}, \mathrm{NO}_{3}^{-}, \mathrm{Cl}^{-}$ \\
\hline 15 & $\mathrm{Zn}>\mathrm{Cu}^{+2}-\mathrm{Cu}^{+1}$ & $\mathrm{La}>\boldsymbol{S n}^{+2} \rightarrow S n^{+4}$ & $A \boldsymbol{c}>\mathrm{OH}^{-}, \mathrm{Cl}^{-}$ \\
\hline 16 & $\mathrm{Mg}>\mathrm{Cu}^{+2}-\boldsymbol{C u}^{+1}$ & $\mathrm{La}>\boldsymbol{S n} \boldsymbol{n}^{+2} \rightarrow \boldsymbol{S n}^{+4}$ & $A c>\mathrm{OH}^{-}, \mathrm{Cl}^{-}$ \\
\hline 17 & $\mathrm{Zn}$ & $\mathrm{La}>S^{+2}$ & $A \boldsymbol{c}>\mathrm{OH}^{-}, \mathrm{Cl}^{-}$ \\
\hline 18 & $\mathrm{Mg}$ & $\mathrm{La}>\boldsymbol{S n}^{+2}$ & $A \boldsymbol{A c}>\mathrm{OH}^{-}, \mathrm{Cl}^{-}$ \\
\hline 19 & $\begin{array}{l}\mathrm{Mg}>\mathrm{Cu}^{++} \text {, and } \\
\mathrm{Cu}^{+2} \rightarrow \mathrm{Cu}^{+1}\end{array}$ & $\mathrm{Al}>\boldsymbol{S n}^{+2} \rightarrow \boldsymbol{S n}^{+4}$ & $\boldsymbol{A c}>\mathrm{OH}^{-}, \mathrm{Cl}^{-}, \mathrm{NO}_{3}^{-}$ \\
\hline 20 & $\begin{array}{l}\mathrm{Zn}>\mathrm{Cu}^{++} \text {, and } \\
\mathrm{Cu}^{+2} \rightarrow \mathrm{Cu}^{+1}\end{array}$ & $\mathrm{Al}>\boldsymbol{S n}^{+2} \rightarrow \boldsymbol{S n}^{+4}$ & $A \boldsymbol{c}>\mathrm{OH}^{-}, \mathrm{Cl}^{-}, \mathrm{NO}_{3}^{-}$ \\
\hline 21 & $\mathrm{Mg}>\mathrm{Cu}^{+2} \rightarrow \mathrm{Cu}^{+1}$ & $\mathrm{Al}>\boldsymbol{S n}^{+2} \rightarrow \boldsymbol{S n}^{+4}$ & $A \boldsymbol{c}>\mathrm{OH}^{-}, \mathrm{Cl}^{-}, \mathrm{NO}_{3}^{-}$ \\
\hline 22 & $\mathrm{Zn}>\mathrm{Cu}^{+2}-\mathrm{Cu}^{+1}$ & $\mathrm{Al}>\boldsymbol{S n}^{+2} \rightarrow \boldsymbol{S n}^{+4}$ & $A \boldsymbol{c}>\mathrm{OH}^{-}, \mathrm{Cl}^{-}, \mathrm{NO}_{3}^{-}$ \\
\hline 23 & $\mathrm{Cu}^{+2} \rightarrow \mathrm{Cu}^{+1}$ & $\mathrm{Sn}^{+2} \rightarrow \mathrm{Sn}^{+4}$ & $\mathrm{Cl}^{-}, \mathrm{OH}^{-}$ \\
\hline
\end{tabular}

$\boldsymbol{A c}=$ acetate 
Table B-3: X-Ray diffraction characteristics of materials synthesized

\begin{tabular}{|c|c|c|c|}
\hline $\begin{array}{l}\text { Sample Number and } \\
\text { Composition, HT-\# }\end{array}$ & \begin{tabular}{|l} 
Quality of \\
Hydrotalcite Peaks
\end{tabular} & $\begin{array}{l}\text { Main Hydrotalcite } \\
\text { Peak Positions - } \AA\end{array}$ & \begin{tabular}{|l|lll} 
Crystalline Phases \\
\end{tabular} \\
\hline $\begin{array}{l}1 \\
\mathrm{Zn}>\mathrm{Sn}^{+2} \\
\mathrm{Al}, \mathrm{SO}_{4}=\end{array}$ & $\begin{array}{l}\text { Broad but well } \\
\text { defined }\end{array}$ & $7.7,4.6,3.3$ & $\begin{array}{l}\text { None, sample is mostly poorly } \\
\text { crystalline to amorphous } \\
\text { materials. }\end{array}$ \\
\hline $\begin{array}{l}2 \\
\mathrm{Zn}>\mathrm{Sn}^{+2} \\
\mathrm{Al}, \mathrm{SO}_{4}=\end{array}$ & $\begin{array}{l}\text { Broad but well } \\
\text { defined }\end{array}$ & $8.0,4.1,2.6$ & $\mathrm{Sn}_{3} \mathrm{O}_{2}(\mathrm{OH})_{2}$ \\
\hline $\begin{array}{l}3 \\
\mathrm{Zn} \\
\mathrm{Bi}, \mathrm{SO}_{4}=\end{array}$ & Almost none & $\begin{array}{l}\text { Poorly defined } \\
\text { shoulder at } 10.4 \text {. } \\
\text { A well developed } \\
\mathrm{Bi}(\mathrm{OH})_{3} \text { peak at } \\
6.8 \text {. }\end{array}$ & $\mathrm{Bi}(\mathrm{OH})_{3}$ and/or $\mathrm{Bi}_{2} \mathrm{O}_{3} \mathrm{CO}_{3}$ \\
\hline $\begin{array}{l}4 \\
\mathrm{Mg} \\
\mathrm{Bi}, \mathrm{CO}_{3}=\end{array}$ & Almost none & $\begin{array}{l}\text { Poorly defined } \\
\text { shoulder at } 10.4 \text {. } \\
\text { A well developed } \\
\mathrm{Bi}(\mathrm{OH})_{3} \text { peak at } \\
6.8 \text {. }\end{array}$ & $\mathrm{Bi}(\mathrm{OH})_{3}$ and/or $\mathrm{Bi}_{2} \mathrm{O}_{3} \mathrm{CO}_{3}$ \\
\hline $\begin{array}{l}5 \\
\mathrm{Zn} \\
\mathrm{Al} \mathrm{SO}_{4}{ }^{=}\end{array}$ & $\begin{array}{l}\text { Relatively well } \\
\text { Developed; mixture } \\
\text { of, two types of } \\
\text { hydrotalcite? }\end{array}$ & $\begin{array}{l}7.2,3.54,3.20, \\
2.71,2.53< \\
8.7,4.37,2.64\end{array}$ & None \\
\hline $\begin{array}{l}6 \\
\mathrm{Mg} \\
\mathrm{Bi}, \mathrm{SO}_{4}=\end{array}$ & Almost none & $\begin{array}{l}\text { Poorly defined } \\
\text { shoulder at } 10.4 \text {. } \\
\text { A well developed } \\
\mathrm{Bi}(\mathrm{OH})_{3} \text { peak at } \\
6.8 \text {. }\end{array}$ & $\mathrm{Bi}(\mathrm{OH})_{3}$ and/or $\mathrm{Bi}_{2} \mathrm{O}_{3} \mathrm{CO}_{3}$ \\
\hline $\begin{array}{l}7 \\
\mathrm{Zn} \\
\mathrm{Bi}, \text { Ac } \\
\text { (Ac =Acetate) }\end{array}$ & $\begin{array}{l}\text { Broad but well } \\
\text { defined }\end{array}$ & $\begin{array}{l}\text { 7.0, 3.7, 2.1<3.2, } \\
3.0,1.64\end{array}$ & $\begin{array}{l}\text { Sharper peaks at } 2.74 \text { and } 1.91 \\
\AA \text { may be salts or off-spec. } \\
\mathrm{Bi}(\mathrm{OH})_{3} \text { and/or } \mathrm{Bi}_{2} \mathrm{O}_{3} \mathrm{CO}_{3}\end{array}$ \\
\hline $\begin{array}{l}8 \\
\mathrm{Zn} \\
\mathrm{Al}, \mathrm{Ac}\end{array}$ & $\begin{array}{l}\text { Well crystallized } \\
\text { hydrotalcite plus } \\
\text { broad peaks }\end{array}$ & $\begin{array}{l}\text { 12.6, 8.7, 4.35, } \\
\text { (all broad) }\end{array}$ & $\begin{array}{l}\text { Analogue to } \mathrm{Mg}-\mathrm{Al}-\mathrm{OH} \text {, see } \\
\# 9 \text { below. }\end{array}$ \\
\hline $\begin{array}{l}9 \\
\mathrm{Mg} \\
\mathrm{Al}, \mathrm{Ac}\end{array}$ & $\begin{array}{l}\text { Well crystallized } \\
\text { hydrotalcite }\end{array}$ & $\begin{array}{l}\text { 7.6, 3.83, } 2.6 \\
\text { (all sharp) }\end{array}$ & $\begin{array}{l}\text { PDF \#48-0601 Hydroxy- } \\
\text { Hydrotalcite - } \mathrm{Mg}_{2} \mathrm{Al}(\mathrm{OH})_{7} \\
\mathrm{Mg}(\mathrm{OH})_{2} \mathrm{Al}(\mathrm{OH})_{3}\end{array}$ \\
\hline $\begin{array}{l}10 \\
\mathrm{Zn} \\
\mathrm{Bi}, \mathrm{Ac}\end{array}$ & $\begin{array}{l}\text { Broad but well } \\
\text { defined }\end{array}$ & $12.3,3.7,3.3$ & $\begin{array}{l}\mathrm{ZnO} \text { and/or } \mathrm{Zn}(\mathrm{OH})_{2}-\text { same as } \\
11\end{array}$ \\
\hline
\end{tabular}




\begin{tabular}{|c|c|c|c|}
\hline $\begin{array}{l}11 \\
\mathrm{Zn}>\mathrm{Cu} \\
\mathrm{Bi}, \mathrm{Ac}\end{array}$ & $\begin{array}{l}\text { Multiple broad low } \\
\text { angle peaks }\end{array}$ & $\begin{array}{l}12.4,9.3,7.3<< \\
3.45,3.30,2.9,2.7\end{array}$ & $\begin{array}{l}\mathrm{ZnO} \text { and/or } \mathrm{Zn}(\mathrm{OH})_{2} \text { - same as } \\
10\end{array}$ \\
\hline $\begin{array}{l}12 \\
\mathrm{Mg}>\mathrm{Cu} \\
\mathrm{Bi}, \mathrm{Ac}\end{array}$ & $\begin{array}{l}\text { Similar to Tsuji, et } \\
\text { al.(2000) but peaks } \\
\text { are offset }\end{array}$ & $\begin{array}{l}8.8,4.8<3.5,3.2, \\
2.9,2.64,2.36 \\
1.98,1.89\end{array}$ & $\begin{array}{l}\text { Nothing obvious - may have } \\
\text { off-spec. } \mathrm{Bi}(\mathrm{OH})_{3} \text { and/or } \\
\mathrm{Bi}_{2} \mathrm{O}_{3} \mathrm{CO}_{3}\end{array}$ \\
\hline $\begin{array}{l}13 \\
\mathrm{Zn}>\mathrm{Cu} \\
\mathrm{Bi}, \mathrm{Ac}\end{array}$ & $\begin{array}{l}\text { Similar to Tsuji, et } \\
\text { al.(2000) but peaks } \\
\text { are offset }\end{array}$ & $\begin{array}{l}8.8,4.8<3.5,3.2, \\
2.9,2.64,2.36 \\
1.98,1.89\end{array}$ & $\begin{array}{l}\text { Nothing obvious - may have } \\
\text { off-spec. } \mathrm{Bi}(\mathrm{OH})_{3} \text { and/or } \\
\mathrm{Bi}_{2} \mathrm{O}_{3} \mathrm{CO}_{3}\end{array}$ \\
\hline $\begin{array}{l}14 \\
\mathrm{Mg} \\
\mathrm{Al}, \mathrm{Ac}\end{array}$ & $\begin{array}{l}\text { Like to Mg-Al-OH } \\
\text { (\#9) but not well } \\
\text { crystallized }\end{array}$ & $\begin{array}{l}7.9,3.9,2.56,2.31 \\
\text { (all broad) }\end{array}$ & None \\
\hline $\begin{array}{l}15 \\
\mathrm{Zn}>\mathrm{Cu}, \mathrm{Sn}^{+2} \\
\mathrm{La}>\mathrm{Sn}^{+4}, \mathrm{Ac}\end{array}$ & $\begin{array}{l}\text { Small broad well } \\
\text { defined }\end{array}$ & $\begin{array}{l}\text { Only one peak at } \\
12.6\end{array}$ & $\mathrm{ZnO}$ all good sharp peaks \\
\hline $\begin{array}{l}16 \\
\mathrm{Mg}>\mathrm{Cu}, \mathrm{Sn}^{+2} \\
\mathrm{La}>\mathrm{Sn}^{+4}, \mathrm{Ac}\end{array}$ & $\begin{array}{l}\text { Very poorly } \\
\text { crystalline }\end{array}$ & $\begin{array}{l}\text { 5.6, 3.2, 2.3, } 1.85 \\
\text { (all very broad) }\end{array}$ & None \\
\hline $\begin{array}{l}17 \\
\mathrm{Zn}>\mathrm{Sn}^{+2} \\
\mathrm{La}, \mathrm{Ac}\end{array}$ & None & None & $\begin{array}{l}\mathrm{ZnO} \text { and four small sharp } \\
\text { peaks at } 3.5,3.28,2.98,1.98 \text {; } \\
\text { may be } \mathrm{Sn}_{6} \mathrm{O}_{4}(\mathrm{OH})_{4}\end{array}$ \\
\hline $\begin{array}{l}18 \\
\mathrm{Mg}>\mathrm{Sn}^{+2} \\
\mathrm{La}, \mathrm{Ac}\end{array}$ & None & None & $\begin{array}{l}\mathrm{Sn}_{6} \mathrm{O}_{4}(\mathrm{OH})_{4}-\text { well expressed } \\
\mathrm{Mg}_{2} \mathrm{La}_{2} \mathrm{SnO}_{7}-\text { poorly } \\
\text { expressed }\end{array}$ \\
\hline $\begin{array}{l}19 \\
\mathrm{Mg}>\mathrm{Cu}, \mathrm{Sn}^{+2} \\
\mathrm{Al}>\mathrm{Sn}^{+4}, \mathrm{Ac} \\
\text { Low } \mathrm{Sn}^{+4}\end{array}$ & Small broad peaks & $7.9,4.0$ & $\operatorname{MgSn}(\mathrm{OH})_{6}$ and/orCuSn $(\mathrm{OH})_{6}$ \\
\hline 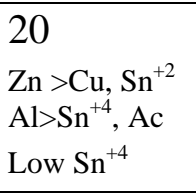 & Small broad peaks & $8.0,4.0,2.6$ & $\mathrm{CuSn}(\mathrm{OH})_{6}$ and $\mathrm{Cu}_{2} \mathrm{O}$. \\
\hline $\begin{array}{l}21 \\
\mathrm{Mg}>\mathrm{Cu}, \mathrm{Sn}^{+2} \\
\mathrm{Al}>\mathrm{Sn}^{+4}, \mathrm{Ac}^{+4} \\
\mathrm{High} \mathrm{Sn}^{+4}\end{array}$ & Small broad peaks & $7.9,4.0,2.55$ & $\mathrm{CuSn}(\mathrm{OH})_{6}, \mathrm{Cu}_{2} \mathrm{O}$, and $\mathrm{CuO}$ \\
\hline
\end{tabular}

Significant differences in peak height is indicated by the < symbol, with listings for the smaller peaks being to the left of the symbol. 
Table B-4: $\mathrm{Log} \mathrm{Kds}$ for $\mathrm{I}^{-}, \mathrm{SeO}_{4}{ }^{=}, \mathrm{ReO}_{4}{ }^{-}$, and $\mathrm{AsO}_{4}{ }^{-3}$ :

$1 \%$ DSSF-7 fluid matrix and 1-day contact times.

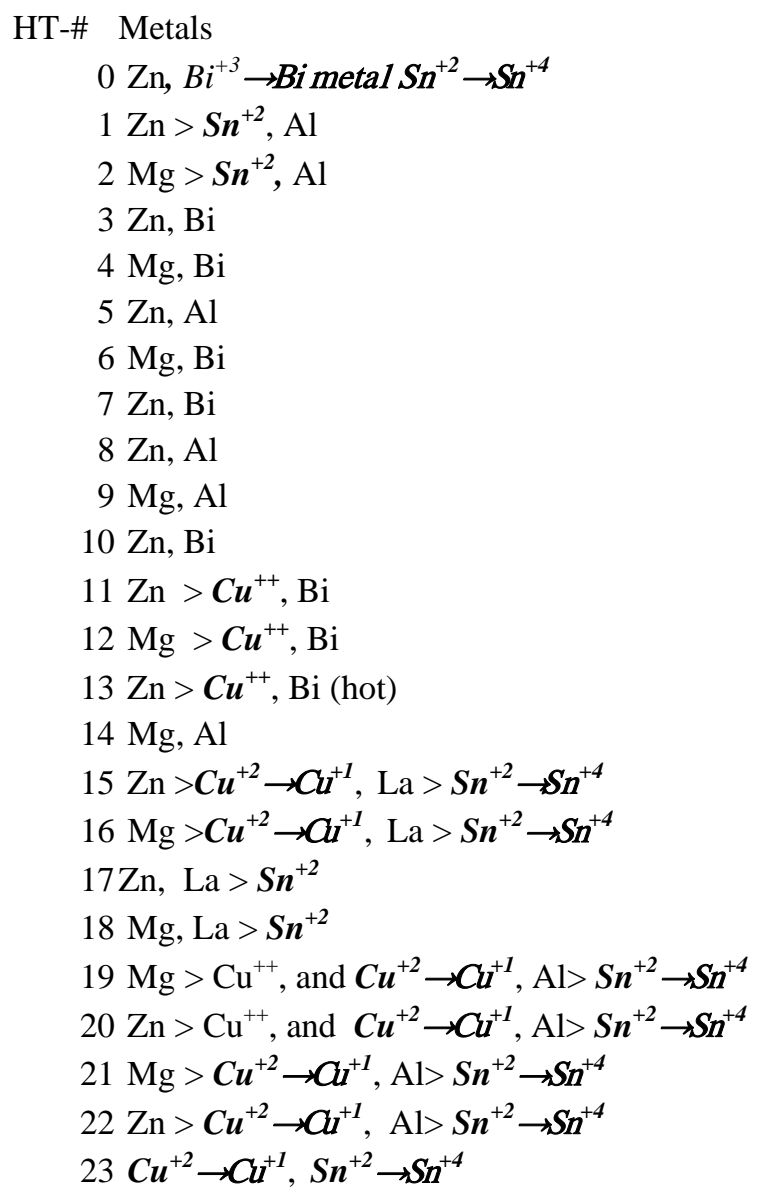

\begin{tabular}{|c|c|c|c|}
\hline $\log \mathrm{Kd}$ & $\log \mathrm{Kd}$ & Log Kd & $\log \mathrm{Kd}$ \\
\hline Iodine & Selenium & $\mathrm{ReO}_{4}^{-}$ & Arsenic \\
\hline No removal & No removal & No removal & 2.27 \\
\hline No removal & No removal & No removal & 3.17 \\
\hline No removal & 1.44 & 0.71 & 2.80 \\
\hline 2.16 & No removal & No removal & 3.05 \\
\hline 1.95 & No removal & No removal & 3.52 \\
\hline No removal & 0.64 & No removal & 3.53 \\
\hline 2.29 & 0.68 & No removal & 3.20 \\
\hline 2.96 & 1.64 & 1.77 & 3.00 \\
\hline No removal & 3.15 & No removal & 4.31 \\
\hline No removal & 2.58 & No removal & 3.82 \\
\hline 2.72 & 1.28 & 1.43 & 3.35 \\
\hline 3.25 & 1.51 & 1.55 & 3.04 \\
\hline 3.53 & 1.40 & 0.81 & 3.28 \\
\hline 1.73 & 3.94 & No removal & 4.6 \\
\hline No removal & 3.41 & 1.24 & 4.34 \\
\hline 2.00 & 0.99 & No removal & 3.60 \\
\hline No removal & 1.55 & No removal & 3.20 \\
\hline No removal & 0.69 & No removal & 3.50 \\
\hline 1.72 & 2.40 & 2.35 & 3.95 \\
\hline 2.12 & 3.63 & 1.08 & 5.43 \\
\hline 1.79 & 3.37 & 0.56 & 4.84 \\
\hline 1.81 & 3.22 & 0.66 & 4.84 \\
\hline 1.17 & 3.49 & 0.72 & 6.12 \\
\hline 2.90 & No removal & No removal & 1.69 \\
\hline
\end{tabular}


Table B-5: Comparison of Log Kd values for 1-day (left) and 26-day contact times (right)

\begin{tabular}{|c|c|c|c|}
\hline & Log Kd & Log Kd & Log Kd \\
\hline HT-\# Metals & $\mathrm{I}^{-}$ & $\mathrm{SeO}_{4}=$ & $\mathrm{ReO}_{4}^{-}$ \\
\hline $0 \mathrm{Zn}, \mathrm{Bi}^{+3} \rightarrow$ Bi metal $\mathrm{Sn}^{+2} \rightarrow \mathrm{Sn}^{+4}$ & N.S., N.S. & N.S., 1.54 & N.S., N.S. \\
\hline & N.S., & N.S., N.S. & N.S., N.S. \\
\hline $1 \mathrm{Zn}>S_{n^{+2}}, \mathrm{Al}$ & 0.64 & & \\
\hline $2 \mathrm{Mg}>\boldsymbol{S n}^{+2}, \mathrm{Al}$ & N.S., N.S. & 1.44 , N.S. & $0.71,0.81$ \\
\hline $3 \mathrm{Zn}, \mathrm{Bi}$ & $2.16,2.75$ & N.S., 1.59 & N.S., N.S. \\
\hline $4 \mathrm{Mg}, \mathrm{Bi}$ & $1.95,2.081$ & N.S., N.S. & N.S., N.S. \\
\hline $5 \mathrm{Zn}, \mathrm{Al}$ & N.S., N.S. & $0.64,1.70$ & N.S., N.S. \\
\hline $6 \mathrm{Mg}, \mathrm{Bi}$ & $2.29,2.84$ & $0.68,1.61$ & N.S., N.S. \\
\hline $7 \mathrm{Zn}, \mathrm{Bi}$ & $2.96,3.79$ & 1.64, N.S. & $1.77,1.75$ \\
\hline $8 \mathrm{Zn}, \mathrm{Al}$ & N.S., 0.92 & 3.15, N.S. & N.S., 0.34 \\
\hline $9 \mathrm{Mg}, \mathrm{Al}$ & N.S., N.S. & $2.58,2.67$ & N.S., 0.40 \\
\hline $10 \mathrm{Zn}, \mathrm{Bi}$ & $2.72,3.90$ & $1.28,1.02$ & $1.43,1.56$ \\
\hline $11 \mathrm{Zn}>\mathrm{Cu}^{++}, \mathrm{Bi}$ & $3.25,4.90$ & $1.51,1.78$ & $1.55,1.50$ \\
\hline $12 \mathrm{Mg}>\mathrm{Cu}^{++}, \mathrm{Bi}$ & 3.53, ---- & $1.40,1.97$ & $0.81,1.12$ \\
\hline $13 \mathrm{Zn}>\boldsymbol{C u}^{++}, \mathrm{Bi}$ (hot) & $1.73,1.62$ & $3.94,3.86$ & N.S., 0.32 \\
\hline $14 \mathrm{Mg}, \mathrm{Al}$ & N.D. 1.66 & $3.41,2.58$ & $1.24,0.46$ \\
\hline $15 \mathrm{Zn}>\mathrm{Cu}^{+2} \rightarrow \mathrm{Cu}^{+1}, \mathrm{La}>\mathrm{Sn}^{+2} \rightarrow \mathrm{Sn}^{+4}$ & 2.00 , N.S. & $0.99,1.74$ & N.S., N.S. \\
\hline $16 \mathrm{Mg}>\mathrm{Cu}^{+2} \rightarrow \mathrm{Cu}^{+1}, \mathrm{La}>\mathrm{Sn}^{+2} \rightarrow \boldsymbol{S n}^{+4}$ & N.D., 1.91 & $1.55,1.92$ & N.S., N.S. \\
\hline $17 \mathrm{Zn}, \mathrm{La}>\boldsymbol{S n}^{+2}$ & N.D., 0.16 & $0.69,1.37$ & N.S., N.S. \\
\hline $18 \mathrm{Mg}, \mathrm{La}>\boldsymbol{S n}^{+2}$ & 1.72 , N.S. & $2.40,1.97$ & $2.35,1.98$ \\
\hline $19 \mathrm{Mg}>\mathrm{Cu}^{++}$, and $\mathrm{Cu}^{+2} \rightarrow \mathrm{Cu}^{+1}, \mathrm{Al}>\mathrm{Sn}^{+2} \rightarrow \boldsymbol{S n}^{+4}$ & $2.12,0.86$ & $3.63,3.56$ & $1.08,0.84$ \\
\hline $20 \mathrm{Zn}>\mathrm{Cu}^{++}$, and $\mathrm{Cu}^{+2} \rightarrow \mathrm{Cu}^{+1}, \mathrm{Al}>\mathrm{Sn}^{+2} \rightarrow \mathrm{Sn}^{+4}$ & $1.79,2.14$ & $3.37,2.28$ & 0.56 , N.S. \\
\hline $21 \mathrm{Mg}>\mathrm{Cu}^{+2} \rightarrow \mathrm{Cu}^{+1}, \mathrm{Al}>\mathrm{Sn}^{+2} \rightarrow \mathrm{Sn}^{+4}$ & $1.81,1.58$ & $3.22,3.20$ & $0.66,0.77$ \\
\hline $22 \mathrm{Zn}>\mathrm{Cu}^{+2} \rightarrow \mathrm{Gl}^{+1}, \mathrm{Al}>\mathrm{Sn}^{+2} \rightarrow \mathrm{Sn}^{+4}$ & 1.17, 1.39 & 3.49, N.S. & $0.72,$. N.S. \\
\hline $23 \mathrm{Cu}^{+2} \rightarrow \mathrm{Cu}^{+1}, \mathrm{Sn}^{+2} \rightarrow \mathrm{Sn}^{+4}$ & $2.90,1.39$ & N.S., 1.58 & N.S., N.S. \\
\hline
\end{tabular}

N.S. = no evidence for sorption. 
Table B-6: Effect of ordinary Portland cement on iodine and selenium sorption:

Log Kd values and final concentrations in - parts per billion;

5 day contact time with OPC, 26 days without OPC, 1\% DSSF-7 matrix)

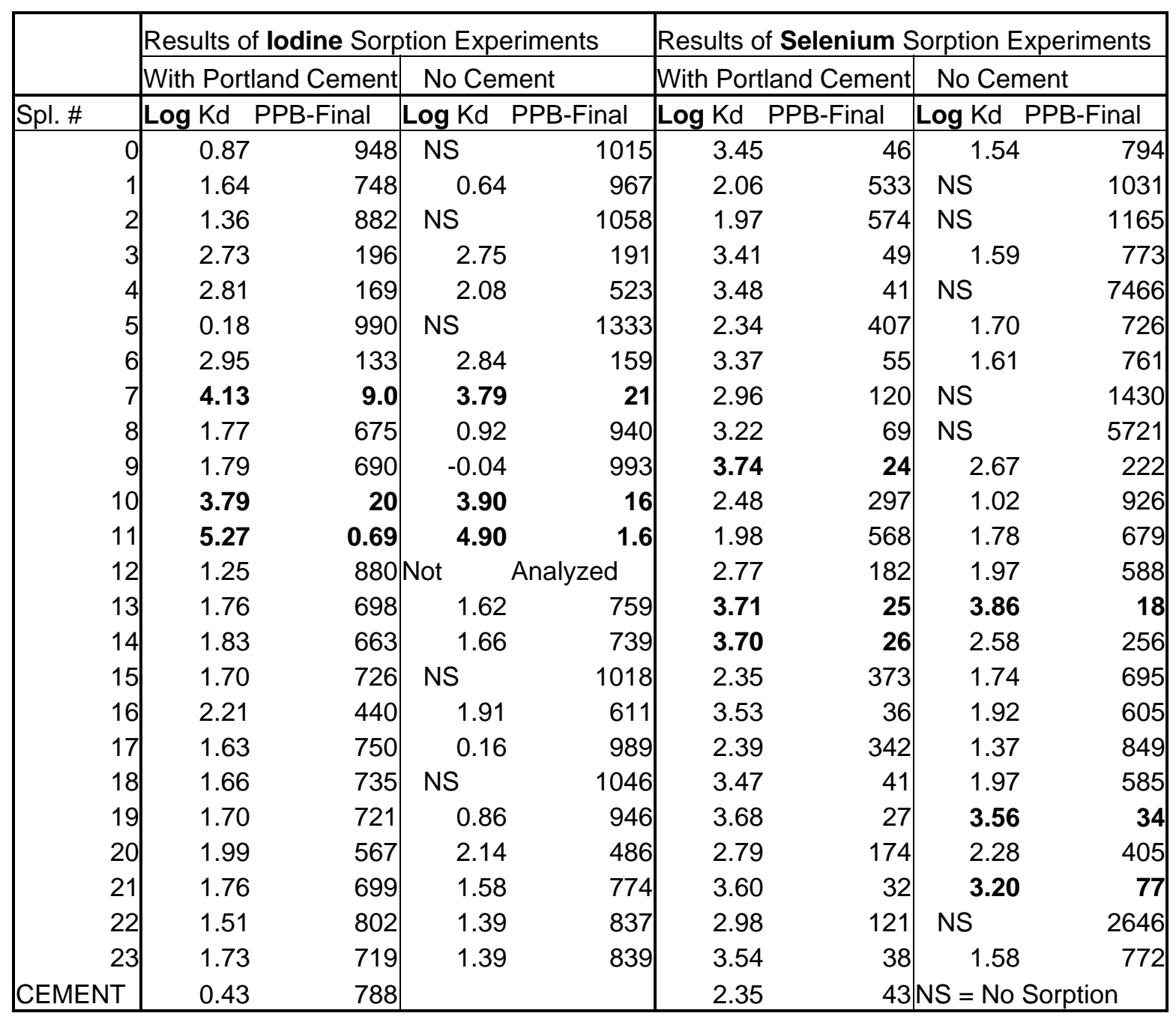


Table B-7: Effect of ordinary Portland cement (“OPC”) on perrhenate sorption:

Log Kd values and final concentrations in - parts per billion;

5 day contact time with OPC, 26 days without OPC, 1\% DSSF-7 matrix)

\begin{tabular}{|c|c|c|c|c|}
\hline \multirow[b]{3}{*}{ HT- \# } & \multicolumn{4}{|c|}{ Results of $\mathrm{ReO}_{4}{ }^{-}$Sorption Experiments } \\
\hline & \multicolumn{2}{|c|}{ With Portland Cement } & \multicolumn{2}{|c|}{ No Cement } \\
\hline & $\log \mathrm{Kd}$ & PPB-Final & $\log \mathrm{Kd}$ & PPB-Final \\
\hline 0 & 1.19 & 899 & NS & 1008 \\
\hline 1 & NS & 1065 & -0.28 & 996 \\
\hline 2 & 0.44 & 979 & 0.81 & 954 \\
\hline 3 & 0.58 & 972 & NS & 1003 \\
\hline 4 & 0.34 & 984 & NS & 1012 \\
\hline 5 & NS & 1026 & NS & 1029 \\
\hline 6 & 0.65 & 969 & 0.03 & 992 \\
\hline 7 & 1.98 & 566 & 1.75 & 702 \\
\hline 8 & NS & 1050 & 0.34 & 984 \\
\hline 9 & 0.43 & 981 & 0.40 & 982 \\
\hline 10 & 1.63 & 746 & 1.56 & 783 \\
\hline 11 & 1.45 & 817 & 1.50 & 802 \\
\hline 12 & 1.09 & 914 & 1.12 & 908 \\
\hline 13 & NS & 1019 & 0.32 & 984 \\
\hline 14 & 0.81 & 954 & 0.46 & 978 \\
\hline 15 & NS & 1059 & NS & 1001 \\
\hline 16 & 0.24 & 986 & NS & 1002 \\
\hline 17 & 1.28 & 872 & 0.08 & 991 \\
\hline 18 & 2.34 & 365 & 1.98 & 579 \\
\hline 19 & 0.94 & 938 & 0.84 & 948 \\
\hline 20 & NS & 1032 & NS & 1013 \\
\hline 21 & 0.89 & 945 & 0.77 & 957 \\
\hline 22 & NS & 1042 & NS & 1019 \\
\hline 23 & NS & 1011 & NS & 1011 \\
\hline CEMENT & NS & 1012 & $N S=1$ & \\
\hline
\end{tabular}


Table B-8: Pertechnetate sorption test results.

Solution concentrations (pCi/ml) at 1 hour, 1 day, 3 days and 7 days. Except for the last tests $\mathrm{Kd}$ values are based on 7-day test results. Desorption concentrations were measured at 1 hour, 1 day and 3 and 7 days. Complete release would result in a concentration of 1,9400 pCi/ml.

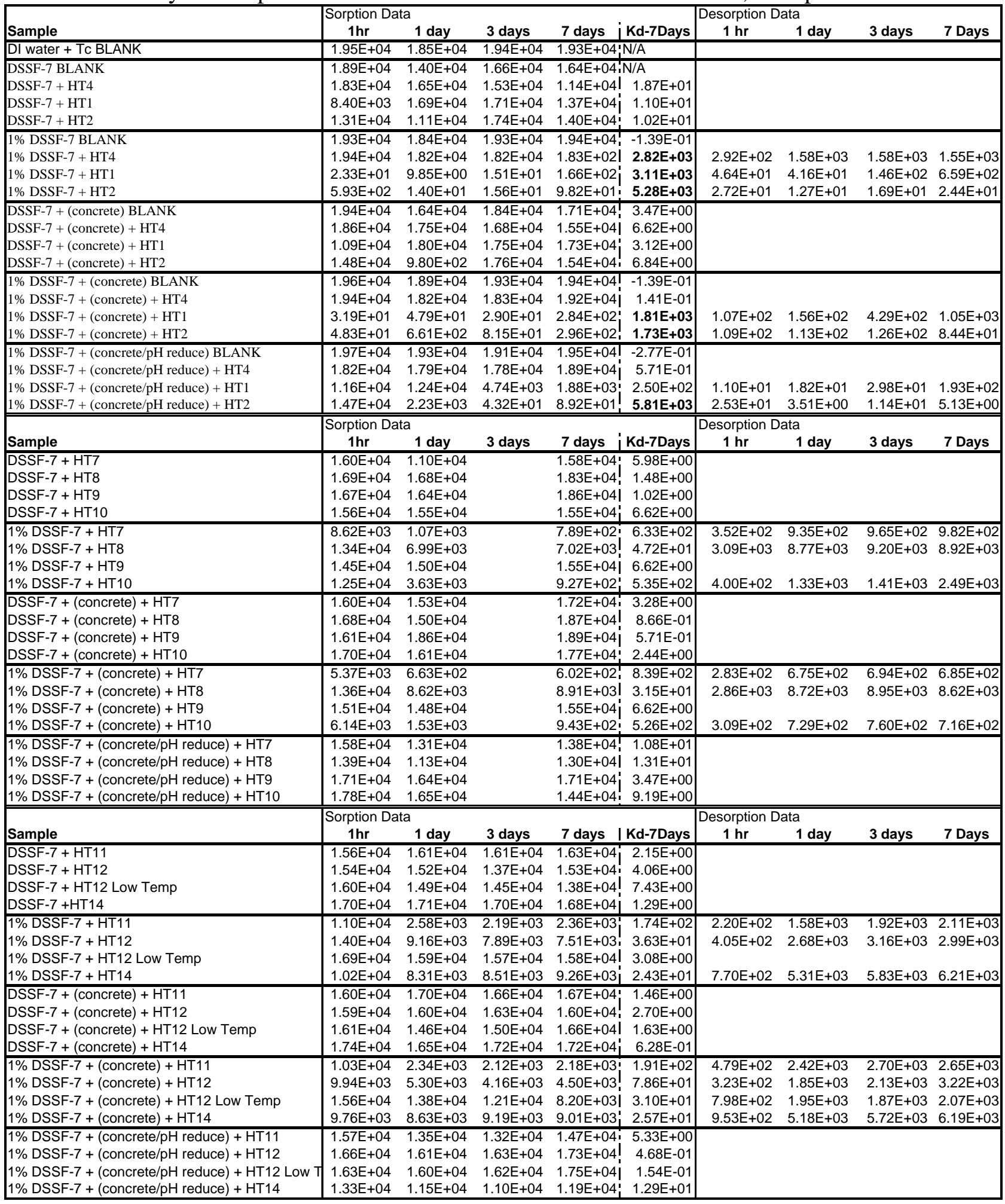


Table B-8 Continued

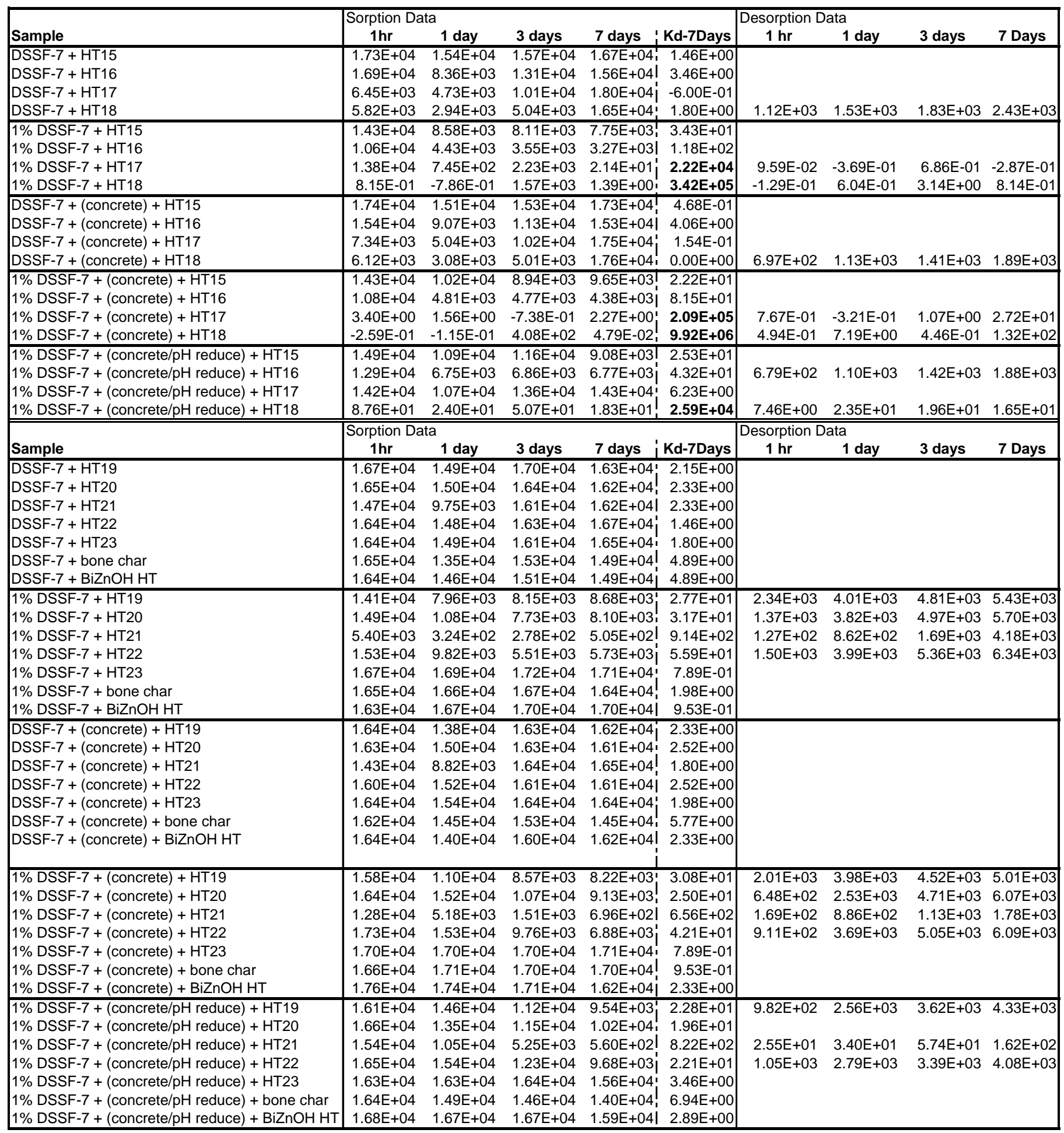


Table B-9: $\mathrm{TcO}_{4}$ - $\mathrm{Kd}$ values (not $\mathrm{Log} \mathrm{Kd}$ ) for selected HT samples:

5\% DSSF-7 fluid matrix and 4 months equilibration time

\begin{tabular}{|l|l|l|}
\hline Sample \# & Replicate Kd values & Average Kd (ml/g) \\
\hline HT-1 & $7.9,9.0$ & 8.4 \\
\hline HT-3 & $1.1, .9$ & 1.0 \\
\hline HT-4 & 256,73 & 164 \\
\hline HT-7 & 139,151 & 145 \\
\hline HT-8 & No sorption & No Sorption \\
\hline HT-10 & 88,96 & 92 \\
\hline HT-11 & 20,21 & 20.5 \\
\hline HT-12 & 51,55 & 53 \\
\hline HT-14 & No Sorption & No Sorption \\
\hline HT-15 & No Sorption & No Sorption \\
\hline HT-16 & 86,209 & 147 \\
\hline HT-17 & 22,65 & 43 \\
\hline HT-18 & 31,31 & 31 \\
\hline HT-19 & $2.2,2.6$ & 2.4 \\
\hline HT-20 & No sorption & No sorption \\
\hline HT-21 & $3.4,2.8$ & 3.1 \\
\hline HT22 & $2.4,0.5$ & 1.5 \\
\hline Bone Char & $7.3,4.5$ & 5.9 \\
\hline & & \\
\hline
\end{tabular}




\section{EXTERNAL DISTRIBUTION}

Deborah Barr (1)

Physical Scientist

RW-631/ HL 1551 Hillshire Drive, Suite A

Las Vegas, NV 89134

Bo Bodvarsson (1)

Lawrence Berkeley National Laboratories

1 Cyclotron Road Mail Stop 90R1116

Berkeley, CA 94720

Robert J. Budnitz (1)

Lawrence Livermore National Laboratories

Mail Stop L-632

Livermore, CA 94551

Rod Ewing (1)

University of Michigan, 425 E. University Ave.

Ann Arbor, MI 48109

Andrew R. Felmy (1)

PNNL

P.O. Box 999 / K8-96

Richland, WA 99352

Glen Fryxell (1)

PNNL

P.O. Box 999/K2-44

Richland, WA 99352

Diane Graziano (1)

Argonne National Laboratories

9700 South Cass Avenue

Building 205 Room 128

Argonne, Illinois 60439

Mic Griben (5)

Science \& Technology Consulting Group, LLC

10153 Vantage Point Court, Suite 100

New Market, MD 21774-6843 
Stephen Hanauer (1)

General Engineer

RW-63/ HL 1551 Hillshire Drive, Suite A

Las Vegas, NV 89134

David T. Hobbs (3)

Westinghouse Savannah River Company

773-A Building

Aiken, S.C. 29898

Michael Hochella (2)

Virginia Polytechnic and State University

Geosciences 5049 Derring Hall

Blacksburg, VA 24061

Jun Liu (2)

PNNL

P.O. Box 999 / K2-50

Richland, WA 99352

Shas Mattigod (3)

PNNL

P.O. Box 999/ K6-81

Richland, WA 99352

Lester Morss (1)

DOE Office of Basic Energy Science, Chemist, SC-22.1/ GTN

1000 Independence Ave., S.W.

Washington, DC 20585-1290

Joe Payer (1)

The Case School of Engineering Materials Science and Engineering, 10900 Euclid Avenue

Cleveland OH 44106-7204

Mark Peters (1)

Los Alamos National Laboratories

P.O. Box 1663 P21 Mail Stop D454

Las Alamos, New Mexico 87545

Jason Pless (3)

Catalytic Solutions Inc

1620 Emerson St

Oxnard, CA 93033 
Choon Quan (1)

OST\&I, Physical Scientist, RW-40/ Fors Building

US. Dept. of Energy 1000 Independence Ave.

S.W. Washington, DC 20585

Kevin M. Rosso (1)

PNNL

P.O. Box 999 / K8-98

Richland, WA 99352

Paige Russell (1)

General Engineer

RW-631/ HL, 1551 Hillshire Drive, Suite A

Las Vegas, NV 89134.

Abe VanLuik (1)

Senior Policy Advisor, RW-63/ HL,

1551 Hillshire Drive, Suite A

Las Vegas, NV 89134

Jeffrey Walker (1)

OST\&I,

General Engineer

RW-40/ Fors Building US. Dept. of Energy

1000 Independence Ave., S.W.

Washington, DC 20585

Dawn Wellman (1)

PNNL, P.O. Box 999/K6-81

Richland, WA 99352

John Wengle (5)

OST\&I, Supervisory Program Analysis

RW-40/ Fors Building

1000 Independence Avenue SW

Washington, DC 20585 


\section{INTERNAL DISTRIBUTION}

1 Ranko Bontchev, 06874, MS-0779

3 Patrick V. Brady, 6118, 0754

1 Charles Bryan, 06855, MS-0778

1 Benjamin J. Chwirka, 06118, MS-0754

1 Carlos Jove-Colon, 6851, 0776

1 Huizhen Gao, 6874, MS-0779

1 Katheryn B. Helean, 06874, MS-0779

2 Kathleen C Holt, 06874, MS-0779

1 Clifford L. Howard, 06855, MS-1399 (Summerlin, Las Vegas)

1 Hong-Nian Jow, 06875, MS-0779

5 Jim Krumhansl, 6118, MS-0754

2 Robert C. Moore, 06872, MS-1136

2 Tina M. Nenoff, 01114, MS-1415

2 May D. Nyman, 06118, MS-0754

1 Peter N. Swift. 06851, MS-0778

1 Yifeng Wang, 06852, MS-0776

2 Central Technical Files, MS-9018

2 Technical Library, MS-0899 